\title{
EFEITO DE FATORES DO SOLO E DE GENÓTIPOS NO CRESCIMENTO, NUTRICÃO E ATIVIDADE DA FOSFATASE ACIDA EM CLONES \\ DE Eucalyptus grandis HILL EX MAIDEN
}

\section{SILVIA CRISTINA VETTORAZZO \\ Biōloga}

Orientador: Prof. Dr. ANTONIO NATAL GONÇALVES

Dissertação apresentada ã Escola Superior de Agricultura "Luiz de Queiroz", da Universidade de São Paulo, para obtenção do título de Mestre em Agronomia - Area de Con centração: "Solos e Nutrição de Plantas". 
Ficha catalográfica preparada pela Seção de Livros da Divisão de Biblioteca e Documentação - PCAP/USP

Vettorazzo, Silvia Cristina

V592e Efeito de fatores do solo e de genótipos no cres cimento, nutrição e atividade da fosfatase ácida em clones de Eucalyptus grandis Hill ex Maiden. Pira cicaba, 1989 .

115p.

Diss.(Mestre) - ESALQ

Bibliografia.

1. Clone de eucalipto 2. Eucalipto - Atividade en zímica 3. Eucalipto - Crescimento 4. Eucalipto - Efeí to do solo 5. Eucalipto - Interação genótipo-ambien te 6. Eucalipto - Nutrição 7. Fosfatase ácida em eu calipto I. Escola Superior de Agricultura Luiz de Queiroz, Piracicaba 
EFEITO DE FATORES DO SOLO E DE GENOTIPOS NO CRESCIMENTO, NUTRIÇÃO E ATIVIDADE-DA FOSFATASE ACIDA EM CLONES

$D E$ Eucalyptus grandis $H i 11$ ex Maiden

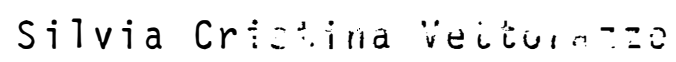

Aprovada em: $26 / 01 / 1990$

Comissão Julgadora:

Prof. Dr. Paulo Yoshio Kageyama

Departamento de Ciēncias

Florestais - ESALQ/USP

Prof. Dr. Antonio Natal Gonçalves

Departamento de Ciēncias Florestais - ESALQ/USP

Prof. Dr. Antonio Roque Dechen

Departamento de Química ESALQ/USP

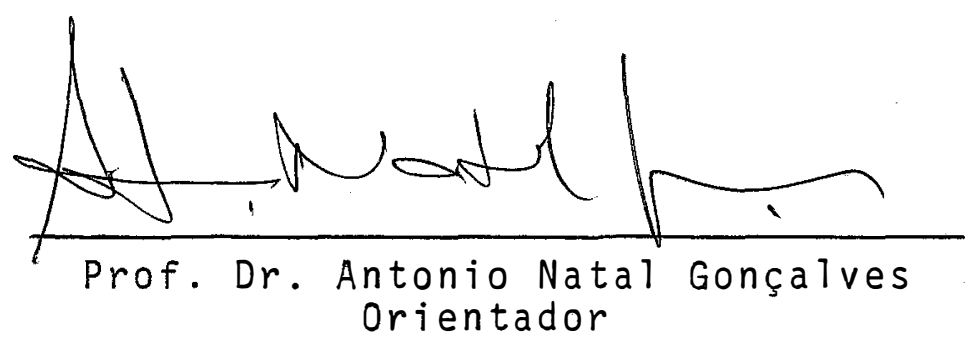




\section{A ADAIL e NELITA}

meus pais,

com muito amor.

A CARMEN, REgINA, LENA, RIA e TUIA

minhas irmãs, pelo apoio em todos momentos. 


\section{AGRADECIMENTOS}

A ESCOLA SUPERIOR DE AGRICULTURA "LUIZ DE QUEI ROZ", pela oportunidade para a realizacão deste curso.

A EMPRESA BRASILEIRA DE PESQUISA AGROPECUARIAEMBRAPA, pela oportunidade concedida.

A COORDENAÇAO DE APERFEIÇOAMENTO DE NIVEL SUPE RIOR-CAPES, pela concessão da bolsa de estudos.

A DURATEX FLORESTAL S.A., pelo suporte financeiro para execução deste trabalho.

Ao Prof. Dr. ANTONIO NATAL GONÇALVES, a quem devo a orientação deste trabalho, e particularmente, pela con fiança e amizade que me ofereceu.

Ao Prof. Dr. OTTO JESU CROCOMO, pela utilização de equipamentos do seu laboratório.

Ao Prof. Dr. QUirino A. DE CAMARgo CARMELlo, pe las anălises químicas de plantas e de solos.

Ao Dr. MURILO DE MELLO, pelas sugestões na anāa lise enzimática e, disposição com que sempre me recebeu. 
Aos Docentes dos Departamentos de Quimica e de Solos, pelos ensinamentos recebidos.

Ao Prof. Dr. PAULO YOSHIO KAgEYAMA, pelas sugestões nas anālises estatísticas dos dados.

Aos colegas VANDA, DIVA, FERNANDO, NORIMAR, DEE NARDIN, CLAUDIMIR, CHALITA, FERNANDA e MIRIAN, pela amizade e companheirismo.

Ao MILTON, pela força que me deu na redação des te trabalho. 


\section{SUMARIO}

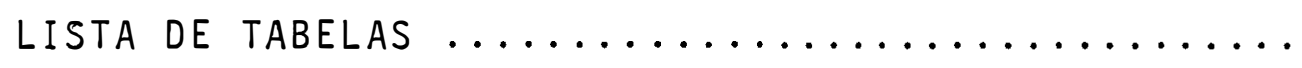

Pāgina

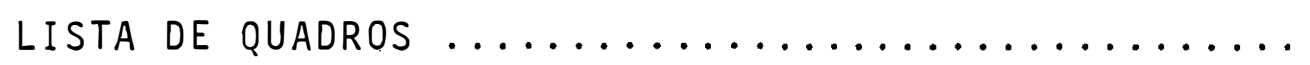

$i x$

RESUMO

$x i i$

SUMMARY

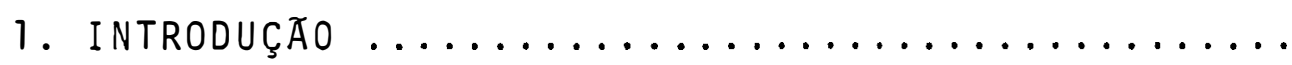

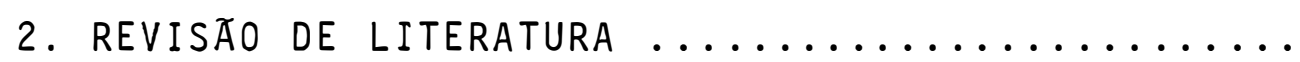

2.1. Características dos solos utilizados para reflorestamento .........................

2.1.1. Caracteristicas fisicas .......... 03

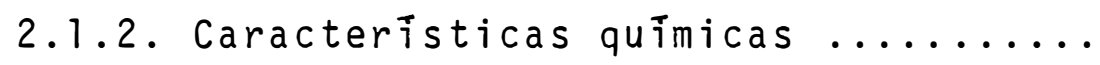

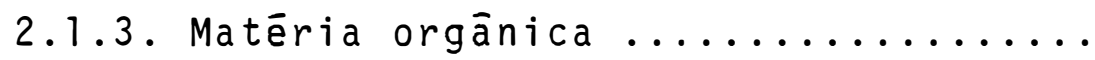

2.2. Avaliação do estado nutricional em eucalip-

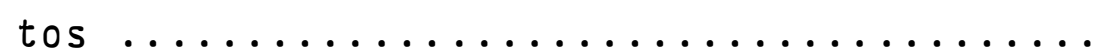

2.2.1. Diagnose do estado nutricional atra-

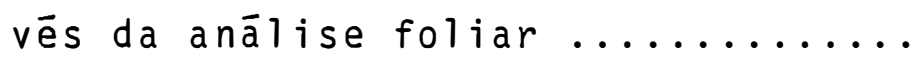

2.2.2. Concentração de nutrientes nas fo-

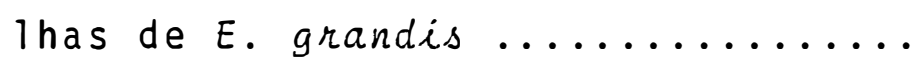

- 2.2.3. Relações entre crescimento, produção de biomassa e concentração de nú

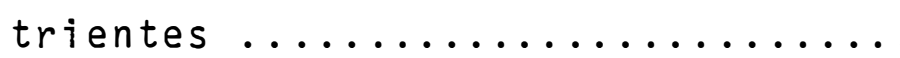

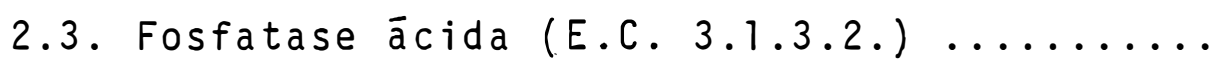

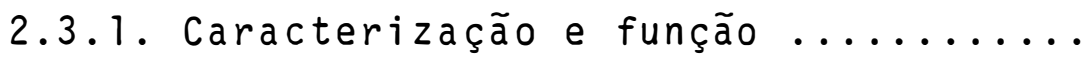

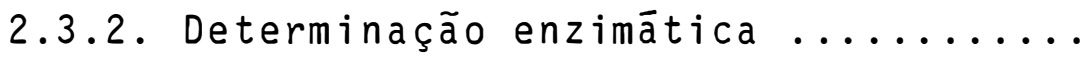

2.3.3. Fatores que afetam a atividade enzi mática

3. MATERIAL E METOdOS ..................... 30

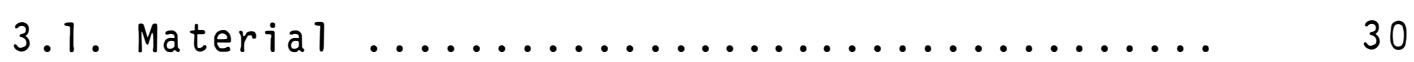

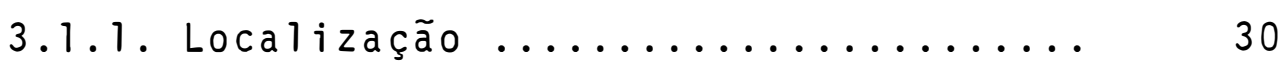

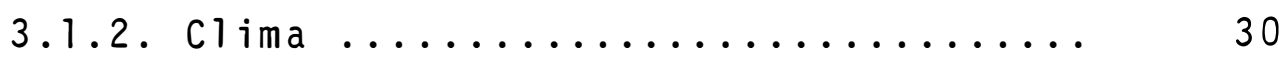


vii

Pàgina

3.1.3. Material genētico ............ 31

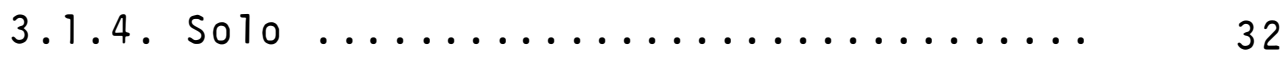

3.1 .4 .1 . Descrição morfológica .... 32

3.1 .4 .2 . Anālise quĩmica ......... 34

3.1 .4 .3 . Anālise física ......... 36

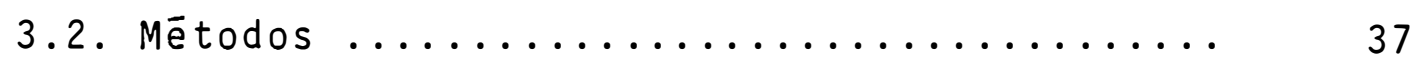

3.2 .1 . Instalação de ensaios ......... 37

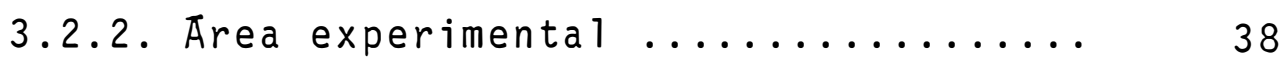

3.2.3. Adubação e manutenção ........... 38

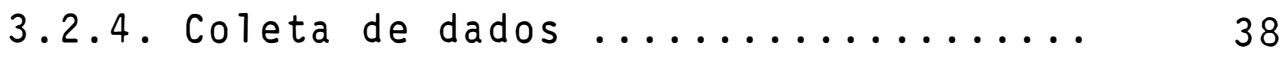

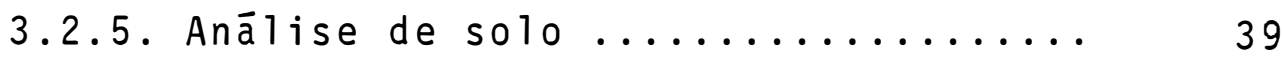

3.2.6. Anālise química de plantas ........ 40

3.2.7. Determinação da atividade da fosfata se ācida ................... 41

3.2.7.1. Extração da enzima e prepa ração de pó acetōnico ..... 42

3.2.7.2. Ensaio enzimātico ....... 42

3.2.8. Anālise estatística ........... 43

3.2.8.1. Anālise de variāncia indivi dual ................ 43

3.2.8.2. Anālise de variāncia conjun ta................. 44

3.2.8.3. Coeficiente de correlação de Spearman ..............

4. RESUltados E discussÃo .................. 47

4.1. Resultados das anālises químicas dos solos. 47

4.1.1. Resultados obtidos nos ensaios aos 54

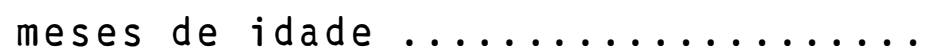

4.1.2. Influência do cultivo de E. grandis nas características químicas dos so-

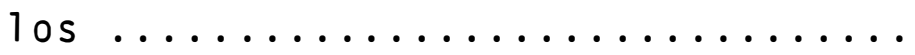


4.2. Efeito de locais no comportamento de clones de E. grandis, aos 18 e 54 meses de idade.

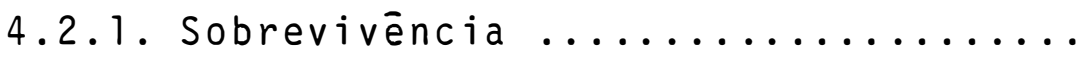

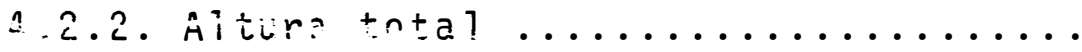

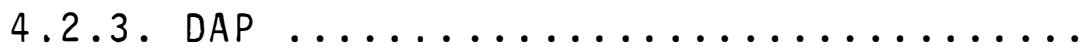

4.2.4. Volume sólido com casca por hectare.

4.3. Concentração de nutrientes em folhas de clo nes de $E$. grandis, aos 12 e 56-57 meses de

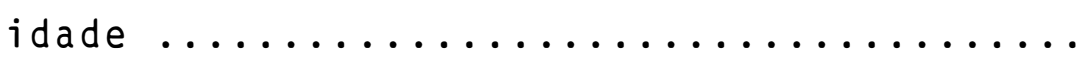

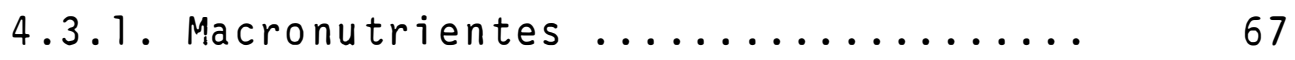

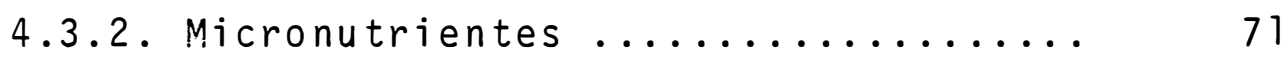

4.3.3. Relações entre nutrientes ......... 74

4.4. Atividade da fosfatase àcida em clones de E. grandis, aos 56-57 meses de idade ...... 4.4.1. Resultado da atividade da fosfata-

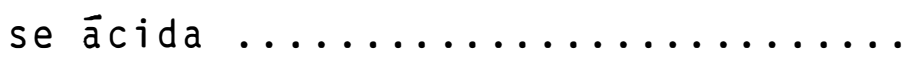

4.4.2. Relação da atividade da fosfatase àcida com altura e $P$ nas plantas...

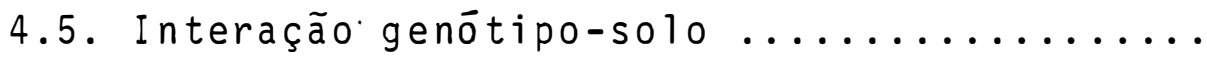

4.5.1. Anālises das variâncias conjuntas ..

4.5.2. Coeficientes de correlação de Spear-

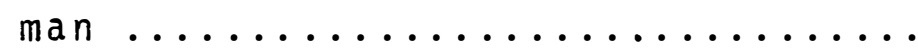

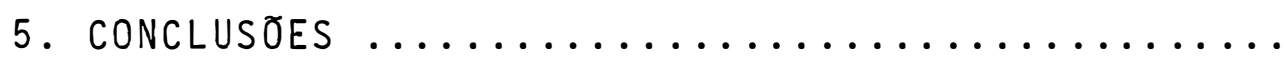

LITERATURA CITADA $\ldots \ldots \ldots \ldots \ldots \ldots \ldots \ldots$ 


\section{LISTA DE TABELAS}

TABELA NO

Pāgina

1 Caracteristicas auimicas obtidas com anālises de terra efetuadas nos dois locais de experimentação ............

2

Caracteristicas fisicas obtidas com anālises de terra efetuadas nos dois locais de experimentação ...........

3 Resultados das anālises quỉmicas efetuadas nos dois locais de experimentação aos 54 meses de idade .........

Comportamento de clones de E. grandis para porcentagem média de sobrevivência, altura total (m), diāmetro à altura do peito - DAP (cm) e volume sólido com casca, por hectare $\left(\mathrm{m}^{3} / \mathrm{ha}\right)$, aos 18 meses de idade, em dois locais do municipio de Lençōis Paulista - SP, e os resultados da anālise de variān-

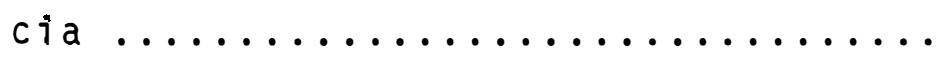

5 Comportamento de clones de $E$. grandis para porcentagem média de sobrevivência, altura total (m), diāmetro à altura do peito - DAP (cm) e volume sólido com casca por hectare $\left(\mathrm{m}^{3} / \mathrm{ha}\right)$, aos 54 meses de idade, em dois locais do municīpio de Lençōis Paulista-SP, e os resultados da anālise de variān

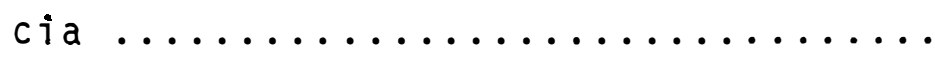


Anālise foliar de macronutrientes em clo nes de E. grandis aos 12 meses de idade, em dois locais do município de Lencóis Paulista-SP, e os resultados da anáilse

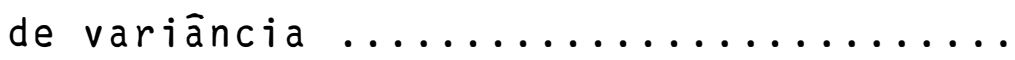

Anālise foliar de micronutrientes em clo nes de $E$. grandis aos 12 meses de idade, em dois locais do municipio de Lençóis Paulista-SP, e os resultados da anāli-

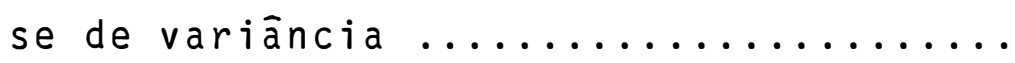

8 Anālise foliar de macronutrientes em clo nes de E. grandis aos 56-57 meses de ida de, em dois locais do municipio de Lençōis Paulista-SP, e os resultados da anā

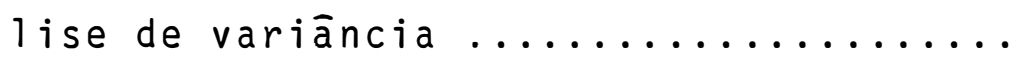

9 Análise foliar de micronutrientes em clo nes de E. grandis aos 56-57 meses de ida de, em dois locais do municipio de Lençōis Paulista-sp, e os resultados da anā

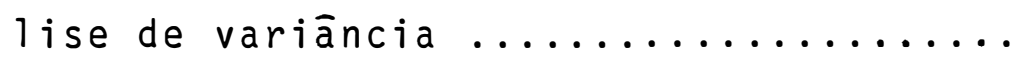

10 Relações entre nutrientes para clones de E. grandis, nos solos Podzólico Vermelho -Escuro e Areia Quartzosa, aos 12 meses

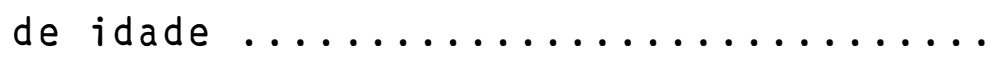

11 Relações entre nutrientes para clones de E. grandis, nos solos Podzólico Vermelho -Escuro e Areia Quartzosa, aos 56-57 me

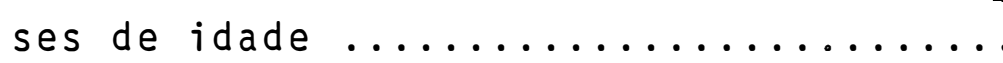


Atividade da fosfatase ācida em folhas de clones de E. grandis, aos 56-57 meses de idade, nos solos Podzölico Vermelho-Escuro e Areia Quartzosa, e os resultados da anālise de variāncia ...

13 Resultados da anālise de variāncia con junta para 15 variāveis, em clones de E. grandis nos dois locais aos 12 e 18 meses de idade, respectivamente, para caracteristicas nutricionais e silvi-

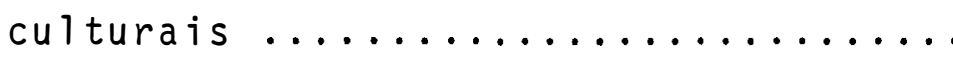

14 Resultados da anālise de variāncia con junta para 16 variāveis, em clones de E. grandis nos dois locais, aos 54 e 56-57 meses de idade, respectivamente, para caracteristicas silviculturais e

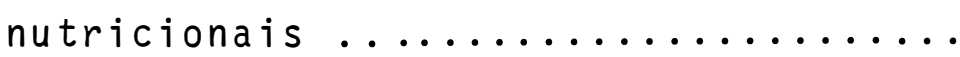

"Coeficiente de correlação de Spearman" $\left(r_{s}\right)$ para as características das plan tas, ao nível de médias de clones, nos dois locais de experimentação - Solo Podzölico Vermelho-Escuro e Solo Areia

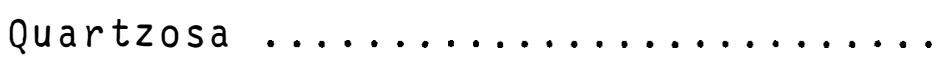

"Coeficiente de correlação de Spearman" $\left(r_{s}\right)$ para as caracteristicas das plan tas, ao nível de médias de clones, aos 12-18 e 54-57 meses de idade ........ 


\section{LISTA DE QUADROS}

QUADRO NO

Número e especificação dos tratamentos para os dois icoáis úe experimentação.

2

Esquema da anālise de variāncia individual para as variāveis estudadas ...

Esquema da anālise de variāncia conjun

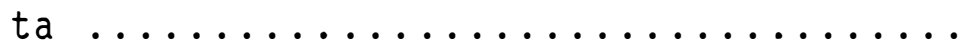


EFEITO DE FATORES DO SOLO E DE GENOTIPOS NO CRESCIMENTO, NUTRIÇAO E ATIVIDADE DA FOSFATASE ACIDA EM CLONES

DE Eucaluptus grandis HILL eX MAIDEN

Autora: Sillvia Cristina Vettorazzo Orientador: Prof. Dr. Antonio ivaiái Gonçalves

\section{RESUMO}

0 presente estudo avaliou o comportamento de 8 clones de Eucalyptus grandis Hill ex Maiden cultivados em dois locais do município de Lençōis Paulista-SP, com condições cli māticas semelhantes e diferenças edáficas. Com base nas propriedades morfológicas, físicas e químicas foram reconhecidas duas classes de solos - Podzólico Vermelho-Escuro (PVE) e Areia Quartzosa ( $A Q)$, que definem os locais experimentais.

0 experimento foi instalado em agosto de 1984 , utilizando o delineamento estatístico de blocos casualizados com 8 tratamentos e 3 repetições.

Foram avaliadas as caracteristicas silviculturais e coletadas amostras de folhas para se estimar concentra ções de nutrientes e atividade de fosfatase ácida. Amostras de terra foram coletadas para se avaliar a disponibilidade de nu trientes. Foram estudadas as variações genēticas, as correlações entre os solos, as correlações entre diferentes idades e as correlações entre características das plantas. 
$x i v$

os resultados da anālise quỉmica de amostras de terra mostraram que, com o avanço da idade do experimento, houve uma tendēncia à redução dos teores de matēria orgānica nos dois solos. Um aumento da acidez e uma redução de $50 \%$

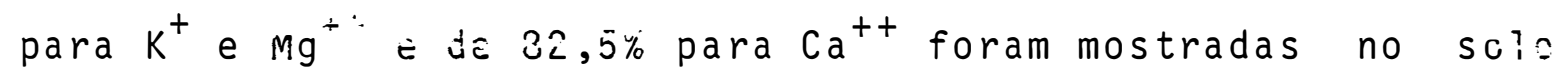
PVE.

A anālise estatistica dos dados aos $12-18$ meses de idade mostrou a existência de variações genēticas entre clones para altura, DAP, volume, sobrevivência e concentra ções de $\mathrm{Ca}$, Mg e Mn no solo PVE, e para DAP, volume e concentrações de $P, K, M g, B, F e$ e $Z n$ no solo AQ. Aos 54-57 meses de idade foram reveladas variações genéticas entre clones para altura, DAP, volume, sobrevivēncia, e concentração de Ca no PVE, e para altura, volume e concentrações de K, Ca e Mn na $A Q$. As variações genēticas entre clones para as caracte risticas silviculturais foram mais marcantes no PVE, para as concentrações de nutrientes foram mais marcantes na $A Q$ na ida de mais precoce.

A anālise de variāncia para atividade da fosfá tase ācida revelou a existência de variações genēticas entre clones no ensaio sob PVE, porém, não houve variação genētica entre clones no ensaio sob AQ. 0 estudo de correlações entre atividade da fosfatase ácida e concentração de $P$, ao nível de médias de clones, não mostrou significāncia aos 54-57 meses de idade. Tendência à correlação negativa entre atividade da fos fatase ācida e altura das plantas foi revelada no ensaio sob $A Q$. 
A interação de clones por locais foi significa tiva para sobrevivēncia e concentrações de $P, K$ e S aos 12-18 meses de idade, e para volume e concentrações de K e Ca aos 54-57 meses de idade.

$$
\text { Para o estudo de cüireíaçoes entre solos, }
$$

nível de médias de clones, foram detectadas correlações positivas e significativas para altura, DAP, volume e concentração de B aos 12-18 meses, e correlações significativas, negativa e positiva, respectivamente para concentrações de Ca e Mg aos 54-57 meses de idade.

As correlações entre idades, ao nível de média de clones, mostraram a existência de correlações positivas pa ra altura e sobrevivência nos dois locais, e para DAP no ensaio sob AQ. Também na AQ foi revelada correlação negativa para concentração de $\mathrm{Mg}$. 
THE EFFECTS OF SOIL FACTORS AND GENOTYPES ON THE GROWTH, NUTRITION AND ACID PHOSPHATASE ACTIVITY IN CLONES OF Eucalyptus grandis HILL ex MAIDEN

Author: Silvia Cristina Vottonrazo Advisor: Prof. Dr. Antonio Natal Gonçalves

\section{SUMMARY}

The present study evaluated the performance of 8 clones of $E$. grandis Hill ex Maiden cultivated in two sites of Lençois Paulista-SP, under similar climatic conditions but with edaphic differences. Based on morphological, physical and chemical properties, two classes of soils were identified Dark Red Podzolic and Quartzous Sand, which defined the experimental sites.

The experiment was set up in August, 1984 using an experimental design of randomized blocks with 8 treatments and 3 repetitions.

The silvicultural characteristics of the stands were evaluated, and samples were taken from leaves to estimate nutrient concentrations and acid phosphatase activity. Soils were sampled to evaluate nutrient availability. Genet:c variations, correlations between soils, correlations between different ages and correlations between plant characteristics were studied.

The results of the chemical analysis of the 
xvi i.

soil samples showed that, during the ageing of the stands, there was decrease in organic material in both soils. An increase in acidity and a reduction of $50 \%$ for $\mathrm{K}^{+}$and $\mathrm{Mg}^{++}$and $82.5 \%$ for $\mathrm{Ca}^{++}$were found in the Dark Red Podzol soil.

A staiistrcal analysis of the date collectea at the age of months showed the existance of genetic variation among clones in relation to tree hight and $D B H$, volume, survival and concentrations of $\mathrm{Ca}, \mathrm{Mg}$ and $\mathrm{Mn}$ in the Dark Red Podzol soil, and for tree $D B H$, volume and concentrations of $P, K, M g$, $B$, Fe and $Z n$ in the Quartzous Sand soil. At the age of 54-57 months genetic variation was observed among clones for tree height and $D B H$, volume, survival and Ca concentrations in the Dark Red Podzol soil, and for tree height, volume and concentrations of $\mathrm{K}, \mathrm{Ca}$ and $\mathrm{Mn}$ in the Quartzous Sand soil. The genetic variation among clones for the silvicultural character istics were most striking in the Dark Red Podzol soil, and were more pronounced for the nutrient concentrations in the Quartzous Sand soil at the early ages.

For acid phosphatase activity the analysis of variance revealed the existance of genetic variation among clones in the Dark Red Podzol site, however, there was no genetic variation among clones in the Quartzous Sand site. The study of correlation between acid phosphatase activity and $P$ concentration, at the level of clone means, showed no significance at the age of 56-57 months. The tendency towards negative correlation between acid phosphatase activity and tree height was revealed in the Quartzous sand site. 
The interaction between clones and sites was significative for survival and concentrations of $P, K$ and $S$ at the age of 12-18 months, and for volume and concentrations of $K$ and $\mathrm{Ca}$ at the age of 54-57 months.

The study of corre? itions between soils, at the level of clone means, detected positive and significant correlations for tree height and DBH, volume and $B$ concentration at the age of 12-18 months, and significant correlations, negative and positive, respectively for $\mathrm{Ca}$ and $\mathrm{Mg}$ concentrations at the age of 54-57 months.

The correlation between ages, at the level of clone means showed the existance positive correlations for tree height and survival at both sites, and for tree DBH at the Quartzous Sand site. Also on Quartzous Sand sites was revealed for Mg concentration. 


\section{INTRODUC,ÃO}

O fenótipo è o reflexo de influēncias genēti cas e ambientais, em certo espaço e tempo; além disso, os ge nōtipos respondem distintamente às variações ambientais. Essa resposta diferencial dos efeitos genotipicos e ambientais nos organismos $\bar{e}$ conhecida com o nome de interação genótipo $x$ ambiente (QUIJADA, 1985).

o nível, ao qual os efeitos da interação genō tipo x ambiente são importantes, varia com a espécie, procedència, progēnie ou clone, e com a característica considerada. Grandes perdas na produção de povoamentos, seja pela mor te das ārvores ou pela redução do crescimento, ou ainda, por ambas as causas, podem ocorrer quando se desprezam os efeitos da interação (PATINO-VALERA, 1986).

Dos fatores ambientais que indicam interações, - mais marcante é o relativo as características do solo, des de que possam ser detectadas dentro de relativamente pequenas āreas, onde não haja variações climāticas (BARROS, 1986).

Do ponto de vista nutricional, o melhor crescimento de um genótipo pode ser decorrente de sua capacidade 
de absorção de nutrientes do solo, ou de sua maior eficiēncia em utilizar o nutriente absorvido na produção de matéria seca.

Medidas da atividade da enzima fosfatase ácida têm sido propostas como um teste bioquīmico ūtil para pre dizer o envoivillento das coiicellirações do fōsforo nas plantas, e uma potencial alternativa de diagnose através de análise foliar de nutrientes.

A fosfatase ācida parece se comportar como uma enzima adaptativa. Assim, sua atividade poderia ser utilizada para distinguir genōtipos melhores adaptados no aproveita mento de fósforo em situações de baixa fertilidade.

Nos programas de melhoramento do eucalipto no Brasil, as caracteristicas fisiológicas e bioquímicas pouco têm sido consideradas, o que constitue num aproveitamento de ficiente de ferramentas preciosas para a seleção de genōtipos mais eficientes na utilização de nutrientes, de grande importāncia para serem utilizadas em solos de baixa fertilidade.

o presente trabalho tem por objetivos: a) ava liar a fertflidade dos solos dos locais de experimentação; b) Estudar as variações genēticas entre clones de Eucaluptus gran dis Hill ex Maiden para as principais características silviculturais, aos 18 e 54 meses de idade; c) Estudar as características nutricionais dos clones, aos 12 e 56-57 meses de idade; d) Detectar as variações da atividade da fosfatase ācida entre clones; e) Verificar as interações clones $x$ solos e clones $x$ idades para as caracterîsticas das plantas; f) Estudar os "coeficientes de correlação de spearman" para as caracteristicas das plantas. 


\section{REVISÃO DE LITERATURA}

2.1. Caracteristicas dos solos utilizados para reflorestamento

A natureza do material parental do solo è geralmente o mais importante determinador das caracteristicas fí sica, química e biológica do solo e, por isto, frequentemente é o principal parâmetro usado na seleção de āreas para plan tios florestais. A influēncia do material parental è refletida atravēs de sistemas de tamponamento no solo (KHANNA \& ULRICH, 1984), que vão atuar sobre a composição da vegetação e taxa de crescimento das árvores.

A maioria das āreas utilizadas para reflorestamento no Brasil originalmente estava sob vegetação de cerra do. Os tipos de solos predominantemente encontrados são os Latossolo Vermelho-Amarelo e Vermelho-Escuro, Podzólico Vermelho-Amarelo e Areia Quartzosa (ADAMOLI et alii, 1986).

\subsubsection{Caracteristicas físicas}

LOPES (1984) relata trabalhos de vārios auto- 
res sobre descrições das características e propriedades físicas dos solos sob cerrado. No geral, esses solos são profundos, sem barreiras para o desenvolvimento de raizes. Com boa estrutura e declive suave.

A textura é, talvez, a mais estāvel e importan te característica física do solo, sendo elemento de grande im portāncia na descrição, na identificação e, posteriormente, na classificação do solo (FOTH, 1984). Além disso, a textura apresenta estreita relação com "fixação" de fósforo, capacida de de retenção de āgua, capacidade de troca de cátions (LOPES, 1984) e influi na maior ou menor quantidade de solo arrastada pela erosão (BERTONI \& LOMBARDI NETO, 1985).

Solos arenosos apresentam boa circulação de ar e baixa capacidade de retenção de āgua. Segundo Grohman (1966), citado por GONÇALVES (1987), a baixa disponibilidade de água deve-se ao alto volume de matēria sólida, baixo teor de argila e baixa microporosidade.

o comportamento de água nos solos reflete a im portāncia da distribuição dos tamanhos dos poros e agregação. Uekara \& Keng (1975), citados por LOPES (1984), afirmam que em solos bem agregados, como a maioria dos latossolos sob cer rado, a āgua pode ser retida em poros inter-agregados de maio res ou menores dimensões.

A baixa capacidade de retenção de água dos solos dos cerrados, a ocorrēncia de veranicos, problemas de toxidez de aluminio e manganês e baixa disponibilidade de nu- 
trientes são apresentados em vārios trabalhos como fatores 1 i mitantes do crescimento do sistema radicular e, consequentemen te, do crescimento da parte aērea das plantas agrícolas (LoPES, 1984; GOEDFRT, 1986; SOUZA \& RITCHEY, 1986) e florestais (MCCOLL, 1969; BARROS, 1974; BOWEN, 1984).

\subsubsection{Características químicas}

o sucesso na utilização intensiva de āreas reflorestadas depende, numa grande extensão, do manejo de nutrientes do solo. Isso envolve um relacionamento entre caracteristicas quimicas e processos do solo que se interagem para a manutenção do suprimento de nutrientes. Característị cas químicas do solo afetam o crescimento das ārvores e, tam bēm, outros processos do ecossistema, como a decomposição da serrapilheira e atividades microbianas (KHANNA \& ULRICH, 1984).

RAIJ \& PEECH (1972) comentam que os solos alta mente intemperizados de regiões tropicais úmidas exibem cargas elétricas positivas e negativas, principalmente dependen tes de pH e, extrema facilidade que os cátions são hidrolisados.

A metodologia para determinação do pH tem considerável influēncia nos resultados da acidez no solo e sua interpretação. SCHOFIELD \& TAYLOR (1955) propuseram a determinação do pH em solução de $\mathrm{CaCl}_{2} 0,01 \mathrm{M}$, por apresentarem mui tas vantagens sobre o método do $\mathrm{pH}$ em $\mathrm{H}_{2} \mathrm{O}$ : a) o $\mathrm{pH}$ medido nes 
sa solução é pouco afetado pela relação solo:solução; b) a quantidade adicionada de sal é suficiente para nivelaros efej tos dos sais normalmente existentes em solos não salinos; a concentração utilizada não é muito diferente, em ordem de grandeza, de concentrações existentes em soluções de solos de alta fertilidade ou bem adubados; d) o cátion cálcio, usado na solução de cloreto de cālcio, é também o mais abundante na solução do solo; e) como as suspensões de solos em $\mathrm{CaCl}_{2} 0,01$ M são floculadas, os erros do potencial de junção líquida podem ser minimizados pela colocação do eletrodo de referēncia no liquido sobrenadante limpido.

Pionke \& Corey (1967) citados por PITTA (1974), mostraram uma alta correlação entre o pH e O $A 1^{3+}$ trocável. Já - $\mathrm{Al}^{3+}$ não trocável correlacionou-se mais com a matéria orgānica.

Segundo RAIJ (1983), a idéia que o alumīnio es tá associado com a acidez de solos e, que este é o responsāvel pela acidez de solos tropicais é um pouco distorcida. Em condições de acidez o aluminio, proveniente principalmente de mi nerais de argila e óxidos de aluminio, surge em solução na forma de cátion $\mathrm{Al}^{3+}$, às custas da dissolução dos minerais do solo. O alumínio em solução passa a ser um cátion trocável; portanto, o $\mathrm{Al}^{3+}$ é consequência da acidez do solo.

A quantidade de cátions trocáveis nos solos depende de seus minerais, da superficie, das cargas do comple xo coloidal e das características dos ions presentes na solu ção do solo (FASSBENDER, 1982). 
Segundo RAIJ (1983), a troca de cátions è um processo reversīvel. Além disso, os cātions podem se movimen tar livremente, não ocupando uma posição fixa, jā que a atração entre os cātions e a superfície é simplesmente atravēs de cargas, ou seja, do tipo eletrostático.

A troca de cátions aumenta na maioria dos solos com a elevação do pH. Com valores muito baixos de pH, ape nas as cargas permanentes das argilas e uma pequena porçãodos colóides orgānicos retêm ions que poderão ser substituĩdos me diante a troca de cátions.

Solos de textura mais fina mostram tendência para maior capacidade de troca de cātions que solos arenosos. o teor de matéria orgānica, assim como a quantidade e o tipo de argila, exercem uma provável influência sobre a capacidade de troca catiónica, num determinado grupo textural (BRADY, $1983)$.

o alto grau de intemperismo da maioria dos solos sob vegetação de cerrado e valores de pH inferiores a 5,0 apresentam, como consequēncia, baixa capacidade de troca catiōnica. LOPES \& COX (1977) observaram que $84 \%$ de 518 amostras superficiais de solos dos cerrados apresentaram valores da troca de cátions inferiores a 2,0 meq/100 $\mathrm{ml}$, e $91 \%$ das amostras analisadas apresentaram toxidez de aluminio, com valores médios de saturação de aluminio de 59\%. Valores acima de $20 \%$ de saturação de Al podem reduzir a produtividade da maioria das culturas (KAMPRATH, 1970). 
Além da capacidade de troca de cátions, a satú ração de bases também é baixa em solos sob cerrado, podendo ocorrer deficiēncia de cālcio, magnésio e potássio. No trabalho desenvolvido por LOPES \& COX (1977), foram encontrados os seguintes valores médios de cātions trocāveis: $\mathrm{Ca}^{++}=0,25$; $\mathrm{Mg}^{++}=0,90 \mathrm{e} \mathrm{K}^{+}=0,08 \mathrm{meq} / 100 \mathrm{ml}$ de solo.

os solos brasileiros apresentam carência generalizada de fósforo solūvel. Os teores de fósforo na solução do solo são em geral baixos, da ordem de 0,1 ppm (partes por milhão), sendo em geral muito mais baixos.

Investigando a influência de algumas. caracte rísticas do solo no comportamento das curvas de adsorção de fósforo, FASSBENDER (1982) encontrou, para muitos solos da América Latina, uma boa relação com óxidos livres de ferro e de alumanio, matéria orgānica e conteúdo de argila.

A influência das reações do solo sobre a disponibilidade de micronutrientes também foi evidenciada por FAS $\underline{S}$ BENDER (1982), mostrando que o teor de cobre, zinco e molibdê nio correlaciona-se diretamente com o pH e, para ferro e boro a disponibilidade é inversamente correlacionada com o pH.

Deficiēncia de boro é frequentemente associada com clima seco e condição de baixa umidade no solo. Parece que a redução na disponibilidade de boro está relacionada à restrita liberação do boro de complexos orgānicos (TISDALE et a 1 i , 1985). 
MALAVOLTA \& KLIEMANN (1985), apresentam uma tabela resumo com as condições do solo e do ambiente que provocam deficiências de micronutrientes. Segundo esses autores, a disponibilidade do manganēs, avaliada pelo $\mathrm{Mn}^{2+}$ presen te, depende do potencial de óxido-redução do solo, da ativida de biológica de bactērias e fungos e do $\mathrm{pH}$.

\subsubsection{Matéria orgānica}

A matēria orgānica se constitui num componente importante da fertilidade do solo, influenciando as caracteris ticas físicas, químicas e biológicas, alterando-lhe para melhor, o nivel de fertilidade e produtividade (MELLO et alii, $1985)$.

Os nīveis crīticos de matēria orgānica do so10, segundo diferentes autores, são apresentados por MELLO et alii (1985), evidenciando as divergēncias na interpretação des ses teores.

Em solos ācidos, ocorre acumulação de matéria orgānica em pH inferior a 5,0. Segundo FASSBENDER (1982), tal fato se deve à diferentes razões: sob condições ācidas a ação bacteriana e a macroflora são limitadas e se favorece a repro dução de fungos, resultando uma menor eficiēncia na mineralização e humificação, com a consequente acumulação de matéria orgānica. Por outro lado, a reação do solo determina a saturação do complexo de troca dos solos; sob condições ácidas au 
menta o Al trocāvel que tem um efeito estabilizante dos complexos organominerais, e tambēm surgem deficiências de Ca e Mg para os microrganismos, acarretando igualmente uma acumula ção de C.

A relação $C / N$ dá informação sobre o estado de humificação da matēria orgānica do solo. O hūmus possui uma relação C/N que varia de 12:1 a 8:1, tendo por média 10:1. Por tanto, quando o resultado da anālise desses elementos apresen ta elevados teores de carbono, em relação aos de nitrogênio (al tas relações $(/ N)$, sabe-se que a matēria orgānica não está completamente humificada, ou ocorreram adições recentes de restos vegetais crus. Inversamente quando os teores de nitro gênio foram elevados dando relações C/N inferiores a 10:1, sü põe-se que houve uma recente adubação nitrogenada (KIEHL, 1979).

Segundo SANCHEZ (1981), a distribuição da matê ria orgānica no perfil em relação a vegetação natural ē a mes ma em regiões tropicais e temperadas. Areas com florestas mostram uma marcada acumulação de matēria orgānica no horizon te A, como resultado da queda de folhas e da morte de raizes.

As taxas anuais de decomposição da matēria orgānica do solo variam consideravelmente, oscilando de 2 a $5 \%$ em florestas tropicais, e nas florestas temperadas variando de 0,4 a $1 \%$, provavelmente como resultado das baixas temperaturas (SANCHEZ, 1981 ).

Os teores da matéria orgānica na maioria dos solos de cerrado situam-se entre 2,0 a $3,0 \%$, o que é conside- 
rado médio. Entretanto, a matēria orgânica encontra-se quase inativa, devido a carência nutricional que caracteriza esses solos (PEREIRA \& PERES, 1986).

\subsection{Avaliação do estado nutricional em eucaliptos}

A baixa fertilidade apresentada nos solos utilizados para reflorestamento, aliada ao mal uso de fertilizantes, e a falta de pesquisas em nutrição mineral de espécies florestais têm levado ao aparecimento de problemas de ordem nutricional nas florestas implantadas no Brasil. VAN GOOR \& NASCIMENTO (1970) e MALAVOLTA et alii (1974) relatam exigências e deficiencias nutricionais em eucaliptos, e sugerem algumas recomendações de adubação.

\subsubsection{Diagnose do estado nutricional através da anālise foliar}

A diagnose foliar como um meio de avaliar o es tado nutricional começou a ser usada no século XX, nos anos 30, com a verificação de que aquela se refletia na composição das folhas, dispensando-se, assim, a anālise da planta inteira (MALAVOLTA \& MALAVOLTA, 1989).

Detalhadas investigações têm definido condições padrões para a realização de anālise foliar de espécies 
florestais, e métodos para interpretar os resultados (LAVENDER, 1970; LEAF, 1972; ARMSON, 1973; DRIESSCHE, 1974).

Desbalanços no fornecimento de nutrientes conduzem a distūrbios nas reações fisiológiras e: podem ser detectados por sintomas de deficiências ou de excessos atravēs de anālises visuais ou quīmicas dos tecidos vegetais. Esses desequilíbrios nutricionais podem não só restringir o cres cimento como, também, promover a incidência de pestes e doenças (BAULE \& FRICKER, 1970).

A anālise foliar é muito útil para o monitoramento do crescimento e do estado nutricional de espécies florestais. No entanto, são conhecidas vārias fontes de variação que precisam ser melhor consideradas na ēpoca de amostra gem, incluindo época do ano, posição da ārvore no talhão, ida de do tecido e posição na copa da árvore, e ano da amostragem (HUMPHREYS et alii, 1972; LEAF, 1972; DRIESSCHE, 1974; SCHONAU, 1981$)$.

$\mathrm{Na}$ interpretação dos resultados das anālises químicas, outras fontes de variação tambēm precisam ser consideradas, incluindo a idade do talhão e a influência de fató res ambientais (LAMBERT \& TURNER, 1988).

Czapowskyj (1979), citado por SILVA (1983), ob servou que as condições de drenagem do solo e as práticas sil viculturais podem influenciar os niveis de nutrientes nas ārvores. 
Segundo FORREST \& OVINGTON (1971), diferenças nas concentrações de nutrientes nas folhas podem ser observadas numa mesma espécie que apresente uma ārea muito ampla ou situada em locais com solos muito heterogêneos.

PAYN \& CLOUGH (1987) citam que a variação sazonal nos nỉveis de nutrientes é muito marcada, e que esta pode ser a principal fonte de erros quando as amostras são co letadas em diferentes épocas do ano.

As concentrações de nutrientes podem variar durante as épocas do ano, comparando-se folhas com a mesma ida de fisiológica, em função da redistribuição dos nutrientes den tro da planta. Quanto à sua redistribuição dentro da planta, os nutrientes podem ser classificados em três grandes grupos: 1) imóveis - Ca e B; 2) pouco móveis (ou intermediārios) - S, $\mathrm{Cu}, \mathrm{Fe}, \mathrm{Mn}$ e $\mathrm{Zn}$; 3) mōveis - N, P, K, Mg, Cl, Mo (MALAvolta \& MALAVOLTA, 1989).

LEAF (1972) e DRIESSCHE (1974) recomendam que a amostragem deve ser feita durante o período de relativamen te baixo crescimento, seguinte a época de crescimento.

Para a maioria das espécies florestais, variações sazonais tendem a diferir marcadamente entre nutrientes com o conteūdo dos elementos mais móveis (N, P, K), tendendo a mostrar baixos níveis no meio do verão ou outono, enquanto elementos menos móveis como o Ca tendem a se acumular durante a estação de crescimento (MEAD, 1984). 
Níveis de nutrientes tendem a ser mais estāveis no outono ou inverno, assim, estas estações têm sido escolhidas como épocas de amostragem nos climas frios e tempera dos (LEAF, 1972). Contudo, dara a máxima sensibilidade da amostragem foliar, ēpocas melhores para amostragem são aquelas quando as árvores estão sob estresse máximo, e istoé, pro vavelmente, imediatamente após a maioria das reservas terem sido remobilizadas para o crescimento. Assim, o final de verão tem sido recomendado por Mead \& Will (1976), citados por MEAD (1984). Para Eucaluptus deglupta nos trópicos, LAMB sugere que para uma melhor amostragem o $K$ deve ser analisado em ēpocas secas, e outros nutrientes (N, P, Ca, B, Cu, Fe, $\mathrm{Zn}$ ) em épocas chuvosas.

Segundo DRIESSCHE (1974), a variação anual na concentração de nutrientes foliares tem magnitude de 15 a $40 \%$ dos niveis mais altos medidos, dependendo do nutriente. o uso de dados climáticos pode reduzir esse problema, desde que a variação anual se correlacione grandemente com as condições climáticas (temperatura e precipitação chuvosa).

Resultados de anālises foliares são altamente dependentes da posição da amostra na ārvore. Quando a posição amostrada não está bem definida num trabalho, os dados não podem ser comparados com outros resultados obtidos pelo mesmo pesquisador ou por outros.

0 padrão de distribuição de nutrientes dentro da copa da árvore foi revisado por DRIESSCHE (1974). Este au- 
tor sugere que provāveis diferenças nos padrões de distribui ção das concentrações de nutrientes, entre diferentes espécies, seja devido ao tipo de fechamento de copa. Por exemplo, num dossel fechado, o sombreamento de porções inferiores da ārvore podem resultar num abaixamento da taxa fotossin tētica, causando menor "diluição de nutrientes" nas folhas pe la produção de novos carboidratos, portanto, maior concentra ção de nutrientes em comparação com as folhas dos ramos superiores (WHITE, 1954 ).

DRIESSCHE (1974) afirma que as diferenças nas concentrações de nutrientes devido ao aspecto da copa podem talvez ser esperadas quando esta é exposta à desigual compet ção ou sombreamento.

MAC LEAN \& ROBERTSON (1981a) relatam a variação no conteúdo de macroelementos em Picea ruben Sarg. com respeito à época do ano, posição na copa, idade da ārvore e da folha, e concluem que todos esses fatores influenciaram nos nīveis dos nutrientes. Foram observados niveis maiores de $N$, P.e Mg na parte superior da copa, enquanto na parte inferior os maiores teores foram de Ca e K.

Em outro trabalho, MAC LEAN \& ROBERTSON (1981b) apresentam as variações de micronutrientes naquelas plantas, e mostram que houve pouco efeito da posição na copa sobre os teores dos micronutrientes, mas houve efeito significativo da idade da ārvore e da folhagem amostrada. 
SNOWDON \& WARING (1982) afirmam que um grande nūmero de amostras de um talhão é necessārio para estimar a concentração mēdia de nutrientes em folhas dentro de limites razoáveis. Cerca de 18 ou mais amostras devem ser requeridas para que o intervalo de confiança seja ao redor de $10 \%$. Se 2 ou mais talhões são comparados, consideravelmente mais amos tras são necessārias. Esses autores evidenciam que, nos experimentos, os níveis de precisão para as anālises foliares são confinados pelo delineamento experimental, repetições e variabilidade dentro de blocos.

SNOWDON \& WARING (1984) examinam vārios mētodos de preparar amostras compostas de folhas anteriores às ana lises quĩmicas. Discutem, tambēm, o problema de se desenvolver um esquema de amostragem que represente adequadamente 0 estado nutricional do talhão e que seja de custo aceitável.

\subsubsection{Concentração de nutrientes nas folhas de} Eucalyptus grandis

KAUL et alii (1968) verificaram efeitos morfológicos das deficiēncias minerais de macronutrientes em plantas de E. grandis aos 8 meses de idade, e as concentrações de nutrientes em plantas normais e deficientes. Observaram que houve aumento na absorção de $\mathrm{N}$ pela deficiēncia de Mg e S, Ca pela deficiēncia de $\mathrm{N}$ e $\mathrm{K}$, e Mg pela deficiēncia de Ca. crescimento em altura foi afetado pela deficiēncia de $N$ e $P$. 
Encontraram nas folhas das plantas controle os seguintes teores de nutrientes: $2,38 \%$ de $\mathrm{N} ; 0,21 \%$ de $\mathrm{P} ; 0,80 \%$ de $\mathrm{K} ; 0,84 \%$ de $\mathrm{Ca} ; 0,29 \%$ de $\mathrm{Mg}$ e $0,33 \%$ de S.

Estudando a concentração de nutrientes em 5 espécies de Eucalyptus, aos 7 anos de idade, em duas localidades, HAAG et alii (1976) observaram que as espécies apresentam concentrações diferentes de nutrientes nas folhas, prin cipalmente para os macronutrientes. Encontraram correlações positivas entre os teores de N, P, K, S e Fe com o volume cilindrico de madeira produzida. Entre as espécies estudadas pelos autores, o E. grandis foi o que apresentou concentra ções mais elevadas de $N, P, K$ e $S$ e maior produção de madeira.

ROCHA FILHO (1979), estudando a interação P, B, Zn e calagem em mudas de $E$. grandis, observou que a calagem reduziu as concentrações de $\mathrm{Zn}$, Mn, Fe e Cu nos tecidos amostrados.

BELLOTE (1979) encontrou maiores concentrações de nutrientes nas folhas de E. grandis, com exceção do Ca, Cu e Mn. Verificou a redução nas concentrações de N, P, K quando comparou plantas com 1 e 7 anos de idade, exceto para $0 \mathrm{~K}$ nas folhas. Para o $\mathrm{Ca}, \mathrm{Mg}, \mathrm{S}, \mathrm{B}, \mathrm{Cu}, \mathrm{Fe}, \mathrm{Mn}$ e $\mathrm{Zn}$, o comporta mento variou em função da parte analisada. Entre os macronutrientes, o Ca foi o elemento mais extraido pelas plantas, vín do a seguir em ordem decrescente: $N, K, S, M g$ e $P$. 
SILVA (1983) estimou a concentração de nutrien tes nas folhas, casca, lenho e o conteúdo de nutrientes, em função da biomassa produzida no tronco, em 5 espēcies de Eucalyptus, aos 10 anos de idade. As concentrações de nutrien tes nos diversos componentes das ārvores apresentaram a seguinte ordem decrescente: folhas, ramos, casca e lenho. Analisando individualmente a concentração de nutrientes nas folhas da parte intermediāria da copa, ressalta-se que E. dunni apresentou os maiores teores de N, P e Mn; E. propinqua os maiores teores de Ca e Mg; E. robusta os maiores teores de $K$ e $Z n$; E. grandis os maiores teores de $\mathrm{Fe}$ e Cu; E. saligna os maiores teores de $M n$ e $\mathrm{Zn}$.

SCHONAU (1983) apresenta os nĩveis ótimos de concentração de nīveis foliares para E. grandis encontrados na Africa do Sul. Os teores ótimos de nutrientes encontrados foram: $N>2,0 ; \quad P=0,16$ a $0,15 \% ; \quad K=0,7 \%$; $\mathrm{Ca}>1,0 \% ; \mathrm{Mg}=0,3 \% ; \mathrm{S}=0,17 \mathrm{a} 0,19 \% ; \mathrm{Zn}<20 \mathrm{ppm} ; \mathrm{Fe}<100$ ppm e $\mathrm{Cu}<18 \mathrm{ppm}$.

HARIDASAN (I985) estudou a concentração de nutrientes na biomassa aērea em plantas de $E$. grandis e $E$. saligna, cultivados em 3 solos de cerrado, durante 3 idades. As plantas de E. grandis acumularam mais nutrientes em solos calcārios que àquelas de E. saligna. Nos solos ācidos, as duas espécies apresentaram acumulação similar de nutrientes. 


\subsubsection{Relações entre crescimento, produção de biomassa e concentração de nutrientes}

Diferenças em crescimento entre espécies

de Eucalyptus, nas diferentes regiões do paîs, segundo GOLFARI (1978), são atribuídas principalmente às diferenças climāticas e as adaptabilidades às condições edāficas.

Comparativamente poucos estudos foram conduzi dos visando relacionar características de crescimento com con centração de nutrientes. Os resultados geralmente são dependentes das características do solo, clima e do material genético utilizado.

LAMB (1977), estudando as relações entre crescimento e concentração foliar de nutrientes em $E$. deglupta, ve rificou diferenças nos níveis de nutrientes, e obteve relação linear entre crescimento e $\mathrm{N} \%$ para um local, mas em outro local o teor de $\mathrm{N}$ não se relacionou com o crescimento. Mos trou, dessa forma, evidencias que as concentrações de nutrien tes em folhas podem variar com solo e idade da planta. O mesmo autor acredita que, pelo desenvolvimento morfológico da maioria das copas de eucalipto seja provável amostrar folhas de uma mesma idade e condição fisiológica em ārvores relativamente jovens.

Poggiani (1983), citado por SILVA (1983), observou diferenças nas concentrações de nutrientes em ārvores com menor ou maior taxa de crescimento em uma população de 
E. saligna, aos 8 anos de idade, plantada em solo pobre, sem adubação. Verificou-se uma concentração mais elevada de nutrientes nas ārvores dominantes, devido a alta taxa de mortalidade. Ao contrārio, num plantio energético cortado aos 2,5 anos de idade e fortemente adubado, houve uma maior concentra ção de nutrientes nas folhas das ārvores dominadas.

SILVA (1983) observou que de 5 espēcies de Eucaluptus estabelecidas em solos de baixa fertilidade, E. gran dis foi a espēcie que mais eficientemente utilizou os nutrien tes $P$ e $K$, em função das produtividades apresentadas, produzindo $34 \%$ a mais de biomassa, e utilizando $15 \%$ a menos de nutrientes do que o E. saligna, que foi a segunda espécie mais produtiva em termos de eficiēncia de utilização de nutrientes.

PEREIRA et alii (1983), trabalhando com E. gran dis observaram que, em relação ao $P$, verifica-se que com o aumento da idade a eficiência de utilização desse nutriente aumenta. Assim, em idades jovens é necessārio muito mais nutrientes para produzir a mesma quantidade de matēria seca.

RODRIGUES (1986), estudando parāmetros silviculturais e suas relações com concentrações de $\mathrm{P}, \mathrm{K}, \mathrm{Ca}$ e $\mathrm{Mg}$ em ārvores de E. saligna, verificou que variações existentes no conteūdo de nutrientes mostram boas perspectivas de utilização desta variāvel para o melhoramento genētico, com possīveis possibilidades de seleção de individuos mais produtivos e eficientes do ponto de vista nutricional. 
LEAL (1988), estudando E. grandis cultivados nas regiões de Bom Despacho e Carbonita, em Minas Gerais, observou atravēs dos coeficientes de utilização biolōgica e ana lîtica, acentuada limitação de crescimento pela deficiēncia de K em Carbonita nos tratamentos com adição de fosfato natural, e deficiēncia de $P$ e Ca nas testemunhas em ambos os locais.

Poucos pesquisadores tēm dado atenção às interações entre nutrientes e o crescimento.

LAMB (197.7), através de equações, mostrou que a altura máxima para Eucaluptus deglupta ocorre quando existe uma taxa de N/P nas folhas de 10,4.

SCHONAU (1983) apresentando teores ótimos de nutrientes em E. grandis, na Africa do Sul, evidenciou a importāncia das relações N/P, N/K, P/K e Ca/Mg. Segundo esse autor os valores ideais foram $N / P=13,0 ; N / K=3,0 ; P / K<0,23$ e $\mathrm{Ca} / \mathrm{Mg}>3,3$.

FERREIRA (1986) avaliou os efeitos da interação $\mathrm{NO}_{3}^{-}, \mathrm{H}_{3} \mathrm{PO}_{4}^{-}$e $\mathrm{SO}_{2}^{-}$na absorção de $\mathrm{H}_{3} \mathrm{PO}_{4}^{-}$e de $\mathrm{SO}_{2}^{-}$, no crescimento e o metabolismo de $\mathrm{NO}_{3}^{-}$e de $\mathrm{SO}_{2}^{-}$em plantas de E.gran dis. Constatou-se como condição ideal que os 3 ànions devem estar juntos para maior influxo de $\mathrm{H}_{3} \mathrm{PO}_{4}^{-}$e $\mathrm{SO}_{3}^{-}$nas raizes, maior crescimento sem distūrbios aparentes no metabolismo de $N$ e $S$.

FURTINI NETO (1988) estudou o efeito do enxofre no crescimento de 5 espécies de eucaliptos. Encontrouque a relação N/S mostrou ser melhor parāmetro para o diagnóstico nutricional das plantas em enxofre, quando comparado ao 
teor de $S$ total. A comparação dos valores das relações $\mathrm{N} / \mathrm{S}$ das diferentes espécies com a produção de biomassa, permitiu verificar que as relações ideais para as espécies ficam entre 15 a 20. A relação N/S ótima para E. grandis ficou próxima a 12. O mesmo autor sugeriu que a relação N/S é mais interes sante que o teor de $S$ para se detectar a deficiencia desse $\bar{u} \underline{1}$ timo nutriente.

2.3. Fosfatase àcida (E.C. 3.1.3.2.)

\subsubsection{Caracterização e função}

A ortofosförico-monoéster-fosfohidrolase (E.C. 3.1.3:2.), conhecida como fosfatase ācida, percence ao grupo das esterases que são enzimas comparativamente de baixa especificidade, embora, sejam especificas para hidrolisar ligações ésteres (DIXON \& WEBB, 1964).

Fosfatases ācidas ocorrem em tecidos animais, plantas, bactérias e leveduras.

A reação baseia-se em:

ortofosförico monoéster $+\mathrm{H}_{2} \mathrm{O}=\overline{\mathrm{a}} \mathrm{lcoOl}+\mathrm{H}_{3} \mathrm{PO}_{4}$

A atividade da fosfatase ācida têm sido demon $\underline{s}$ trada, intracelularmente e extracelularmente, atravēs de técnicas bioquimicas e histoquímicas. 
Estudos histoquímicos desenvolvidos por SHAYKH \& ROBERTS (1974) mostram que a fosfatase àcida não especīfica localiza-se predominantemente na epiderme, córtex e coifa de raiz; assim, esse sistema pnde estar envolvido nos processos de absorção ou secreção. Embora a função dessa atividade enzimātica superficial não esteja esclarecida, essa enzima po de ter um papel na utilização de compostos orgānicos do solo. De acordo com Sentenac et alii (1980), citados por MENGEL \& KIRKBY (1982), as paredes celulares das raizes têm alta atividade de fosfatase. As fosfatases "mineralizam" fosfato de fitinas, àcidos nucleicos e fosfogliceratos. Tambēm, tem sido sugerido que a atividade de fosfatases de micor riza esteja relacionada com a habilidade desses organismos de mobilizar o P do solo.

Moog (1958), citado por NEWMARK \& WENGER (1960), sugeriu, com base em estudos de padrões de desenvolvimento de embriões de aves, que a atividade da fosfatase ācida por ser relativamente constante durante o crescimento seria uma enzima constitutiva, enquanto que a atividade da fosfatase alcal $\underline{i}$ na por apresentar flutuações seria uma enzima adaptativa. Segundo NEWMARK \& WENGER (1960), tal fato não ocorre nas plantas, pois a fosfatase ācida parece ser uma enzima adaptativa, e em plantas a atividade da fosfatase alcalina não aparece ou è muito baixa.

MCLACHLAN (1976) tambēm sugere que a fosfatase seja uma enzima adaptativa, e que sua atividade pode ser uti- 
lizada para distinguir espēcies melhores adaptadas para aproveitar o fósforo existente em situação de baixa disponibili dade.

0 papel das fosfatases externas na nutrição do Tósfóc sm piantas ainda não está claro. A atividucie pode ser devido ao transporte do fósforo inorgānico, ou associada com a conversão de formas orgānicas em inorgānicas (BIELESKI, 1973 ).

Alguns pesquisadores citados por BAKER \& TAKEO (1973) sugerem que a fosfatase ácida interna possa, sob certas circunstāncias, estar envolvida na mobilização de reservas de nutrientes (Flynn \& Smith, 1967), transporte ativo de açūcares ou outras substāncias atravēs da membrana (Figier, 1968), diferenciação de plastīdeos (Mlodianowski, 1972), e no começo e desenvolvimento de senescēncia (De Leo \& Sacher, $1970)$.

Muitos trabalhos têm mostrado que a atividade de fosfatase ācida em plantas aumenta com a diminuição do fós foro disponivel no meio de crescimento, seja este solo ou solução nutritiva, sob condições estéreis ou não. Parece possível que a extensão desse aumento da atividade da enzima pos sa ser controlado geneticamente, como ocorre em Neurospora crassa (HAN \& ROSSI, 1989), no sistema repressível de fosfato, que consiste de vārias enzimas e permeases.

HEWITT \& TATHAM (1960) relatam um aumento de 20 vezes na atividade da fosfatase ācida em folhas de tomateiro deficientes em fósforo. 
PRICE (1962) evidencia que o possivel mecanismo de repressão fosfato-atividade da fosfatase ācida no metabolismo do fósforo possa ocorrer na maioria das plantas.

UEKI \& SATO (1977), estudando a regulação da sintese de fosfatase em cultura de células de Nicotiana tabacum, separando fosfatases intracelulares das extracelulares, observaram que, após adição de Pi, a sīntese de fosfatase é reprimida, mas não ocorre a inativação das enzimas prē-existen tes.

A atividade da fosfatase ácida provavelmente depende de vārios fatores como espécie de planta, tecido, idade e concentração de fósforo no meio de crescimento.

Espécies de plantas diferem grandemente na capacidade de obter fósforo de solos com baixa disponibilidade desse nutriente. A fosfatase ācida nas raízes das plantas pode contribuir para essas diferenças entre plantas na capacidade de absorção de fosfatos.

BESFORD (1978) sugere que a atividade da fosfatase pode ter potencial como indice bioquímico de deficiên cia de P, visto a resposta ser grande e ocorrer antes do aparecimento de sintomas de deficiēncia.

Estudos com trevos deficientes em fósforo, mos traram que a atividade de paredes celulares foi afetada pela idade da planta e concentração de fósforo do meio de crescimen to. Em situação de estresse de P, ocorre aumento de atividade da enzima de paredes celulares de raízes e diminuição na 
concentração de $P$ na raiz, antes que o aparecimento da planta seja afetado (DRACUP et alii, 1984).

\subsubsection{Determinação enzimātica}

Deficiēncias minerais podem causar profundas mudanças no padrão geral da atividade enzimätica nas plantas, mesmo quando os elementos deficientes não estão diretamente envolvidos na ativação de algumas enzimas.

os métodos comumente usados para diagnosticar deficiências nutricionais consistem de avaliações de sintomas visuais, e anālises de folhas e de solos. Contudo, esses métodos podem ser imprecisos, trabalhosos, ou os sintomas podem aparecer muito tarde para serem remediados sem perdas signifi cantes de produção (EPSTEIN, 1975). Assim, tornou-se interes sante o uso de enzimas como marcadores bioquimicos de deficiência de nutrientes.

BESSEY et alii (1946), descreveram um método de colorimetria rāpida, que pode ser usado para macro ou microdeterminações, para medir a atividade de fosfatase alcalina no soro sanguíneo, empregando o substrato p-nitrofenil fos fato. O substrato p-nitrofenil fosfato é incolor, mas sob presença do grupo fosfato, o sal de p-nitrofenil é liberado e se torna amarelo em pH alcalino (absorção māxima próxima a $400 \mathrm{~nm})$. 
0 método de colorimetria rāpida de BESSEY et alii (1946) foi adaptado por vārios pesquisadores para analisar a atividade da fosfatase àcida em tecidos vegetais.

A determinação enzimática pode ser feita atravēs de mëtodos "in vivo" e "in vitro", baseados em princīpios de colorimetria.

Métodos "in vivo" são utilizados principalmente para raizzes (MCLACHLAN, 1980) e folhas (BESFORD, 1980), são bastante interessantes pois não destroem o material analisado, alēm de bastante rāpidos. Raĩzes ou partes de folhas são incubadas em solução tampão, contendo o substrato p-nitrofenilfosfato, ou outro, e a leitura da absorbāncia é feita em espectrofotōmetro a 400-420 nm. Essa metodologia é ūtil para analisar fosfatases do tipo extracelular, presentes principal mente nas paredes celulares de raizes.

Métodos "in vitro" são mais refinados, e utili zam princípios de extração e purificação de tecidos vegetais em soluções tampões (BARRETT-LENNARD \& GREENWAY, 1982). São métodos interessantes para estudos do metabolismo de fósforo, e suas relações com outros nutrientes.

\subsubsection{Fatores que afetam a atividade enzimātica}

A atividade da fosfatase ācida pode ser, como qualquer outra enzima, afetada pela concentração e tipo de substrato, pH do meio, temperatura, presença de ions na 
solução, e principalmente, do tecido analisado e estado fisiológico deste material.

Na maioria dos trabalhos publicados observa se uma tendēncia à utilização de substrato p-nitrofenil fosfato por ser bastante sensỉvel. 0 pH ótimo tem variado de 5,0 a 5,8, e a temperatura ótima do meio de incubação entre 250 a 370 C ou até mais.

SHAW (1966), estudando folhas de fumo, verificou que a presença de $\mathrm{Mg}^{++}, \mathrm{Mn}^{++}, \mathrm{Ca}^{++}, \mathrm{Co}^{++}$e $\mathrm{Ni}^{++}(5 \mathrm{mM})$ não tiveram efeito significativo na atividade da fosfatase ácida. Agentes metálicos complexantes, como EDTA (10 mM) e KCN(5mM), tambēm não afetaram a atividade. $\mathrm{Cu}^{++}, \mathrm{Fe}^{+++}$e $\mathrm{Zn}^{++}$(5mM), reduziram a atividade da fosfatase em 10 a $40 \%$, comparando-se com as reações sem a presença destes metais.

BAKER \& TAKEO (1973) estudando a atividade da fosfatase àcida em folhas de chā e frutos de tomateiro, verificaram inibição do tipo não competitiva pelo fluoreto.

HASEGAWA et alii (1976) evidenciam que a fosfa tase ácida de debris de paredes e citoplasma diferem nas suas afinidades e sensibilidade para alguns substratos e inibidores testados. Mas a enzima tem se mostrado similar quanto ao pH, considerada enzima dependente de pH. Esses mesmos autores observaram que as reatividades de 5 fosfatases ācidas (isoenzimas) não foram significantemente influenciadas pelo $\mathrm{Mg}^{++}, \mathrm{Ni}^{++}, \mathrm{NaCN}$, EDTA. Contudo, $\mathrm{Hg}^{++}$inibiu completamente a atividade das isoenzimas; $\mathrm{Cu}^{++}$e $\mathrm{Zn}^{++}$tiveram efeito inibitó 
rio em algumas enzimas. Um tīpico inibidor de fosfatase ācida, NaF, inibiu todas as 5 fosfatases ācidas até um máximo de $50 \%$. O reagente sulfidrico p-cloro mercuribenzoato afetou as atividades de todas as enzimas, em graus variados.

BARRETT-LENNARD et alii (1982) observaram que em folhas de trigo submetidas à dēficit hîdrico houve redução da - atividade da fosfatase ācida. 


\section{MATERIAL E MÉTODOS}

\subsection{Material}

o experimento foi instalado no municipio de Lençōis Paulista, SP, nas fazendas Rio Claro e Piracema, de propriedade da DURATEX FLORESTAL S/A.

3.1.1. Localização

- Altitude: $600 \mathrm{~m}$.

- Latitude: 220.45'

- Longitude: 48049'

\subsubsection{Clima}

o tipo climático regional pela classificação de KOeppen è o "Cwa", mesotérmico ümido, com inverno seco, no qual a temperatura do mês mais quente ultrapassa os $220 \mathrm{C}$ e a 
temperatura do mês mais frio é inferior a $180 \mathrm{C}$, sendo as chuvas do mès mais seco inferiores a $30 \mathrm{~mm}$ (BRASIL, 1960).

No período de junho de 1984 a maio de 1989, a precipitação média anual nos locais de experimentação foi de $1318 \mathrm{~mm} / a n o$, a temperatura média māxima de $27,90 \mathrm{C}$ e a temperatura média minima de 11,80 C. Resumo dos dados meteorológicos durante o periodo experimental è apresentado no Apēndice 1 .

\subsubsection{Material genētico}

$\mathrm{Na}$ Fazenda Rio Claro foram selecionadas oito matrizes de Eucaluptus grandis entre setembro de 1982 a fevereiro de 1983. As ārvores matrizes destacavam-se das demais nos povoamentos comerciais da DURATEX FLORESTAL S/A pelo vigor, retidão do fuste, resistência à pragas e doenças, características favorāveis quanto à desrama natural e volume de copa.

As matrizes foram estabelecidas com sementes provenientes de Natal, Austrālia, em espaçamento de $3,0 \times 1,5$ m, em solos com baixa fertilidade, classificados como Areia Quartzosa e Latossolo. Na época da seleção, aos 6,11 a 8,4 anos de idade, a altura média estava entre 17,5 a $23,0 \mathrm{~m}$, 0 DAP de 11,5 a $14,2 \mathrm{~cm}$ e a produtividade (Incremento Mēdio Anual - IMA) de 44,7 a 98,2 st/ha/ano. 
Outras informações acerca das matrizes selecio nadas nos ensaios encontram-se no Apēndice 2.

Após o abate dessas matrizes, foram coletados material vegetativo das touças para produção de mudas através de estaquia.

\section{1 .4 . Solo}

0 experimento foi instalado em dois locais, que foram caracterizados quanto a morfologia, anālise química e física de solos.

\subsubsection{Descrição morfológica}

A - Ensaio da Fazenda Rio Claro

- Classificação: Podzōlico Vermelho Escuro (PVE) eutrófico A moderado, textura média.

- Material local: Plano

- Relevo regional: Suave Ondulado

- Drenagem: boa

- Ap: 0-16 cm;2,5 YR 3/2; barro argilo-arenoso; moderada a fraca; pequena, granular e blocos; muito friável, ligeiramente plástico e ligeiramente pegajoso; transição clara e ondulada; raízes abundantes, muito finas e mēdias.

- A3: 16-33 cm;2,5 YR 3/4 (2,5 YR 2/4); barro argilo-are noso; maciço coeso; muito duro; friāvel; plástico e 
pegajoso; transição difusa e plana; raỉzes comuns, muito finas e finas.

- B21: 33-85 cm;2,5 YR 3/4 (2,5 YR 2/4); barro argiloargiloso: moderada, médio; prismātica; duro; muito friā vel, plástico e pegajoso; transição difusa e plana; raí zes comuns, muito finas e finas.

- B22: 85-148 cm;2,5 YR 3/6 (2,5 YR 3/4); barro argi10argiloso; moderada; mēdio; prismas e blocos; duro; muito friāvel, plástico e pegajoso; transição difusa e plá na; raizes comuns.

- B3: $148 \mathrm{~cm} \mathrm{+;} \mathrm{2,5} \mathrm{YR} \mathrm{3/6} \mathrm{(2,5} \mathrm{YR} \mathrm{3/4);} \mathrm{barro} \mathrm{argiloso;}$ maciça porosa; ligeiramente duro; muito friāvel; ligeiramente plástico e pegajoso; transição difusa e plana; raizes comuns.

B - Ensaio da Fazenda Piracema

- Classificação: Areia Quartzosa Alica (A.Q.)

- Material originário: Arenito Bauru

- Relevo local: Plano

- Relevo regional: Suavemente ondulado

- Drenagem: boa

- Ap: 0-17 cm; 10 YR 5/3; areia; maciça porosa, que se desfaz em grãos simples: solto; muito friāvel, não plás tico e não pegajoso; transição gradual e plana; raĩzes abundantes, médias a finas. 
- A3: 17-42 cm; 10 YR 5/3 (10 YR 4/3); areia; maciça porosa, que se desfaz em grãos simples; solto; muito friā vel, não plāstico e não pegajoso; transição difusa e plana; raizes abundantes, médias e finas.

- C1: 42-128 cm; 10 YR 6/4 (10 YR 4/4); areia; maciça po-. rosa, que se desfaz em grãos simples; solto; muito fria vel, não plāstico e não pegajoso; transição difusa e plana; raizes abundantes, mēdias e finas.

- C2: 128-160 cm +; 10 YR 5/4 (10 YR 4/4); areia, maciça, que se desfaz em grãos simples; solto; muito friāvel, não plāstico e não pegajoso; raỉzes abundantes, médias e finas.

\subsubsection{Anālise quỉmica}

Para a caracterização e diagnóstico de fatores limitantes foram procedidas anālises de amostras de terra, coletadas em agosto de 1984, cujos resultados são apresentados na Tabela 1 .

Amostras de terra foram coletadas superficialmen te nas trēs parcelas nos dois locais de experimentação, cujos solos foram classificados como Podzólico Vermelho-Escuro (PVE) e Areia Quartzosa (AQ) e posteriormente foram preparadas amos tras compostas para cada local. 


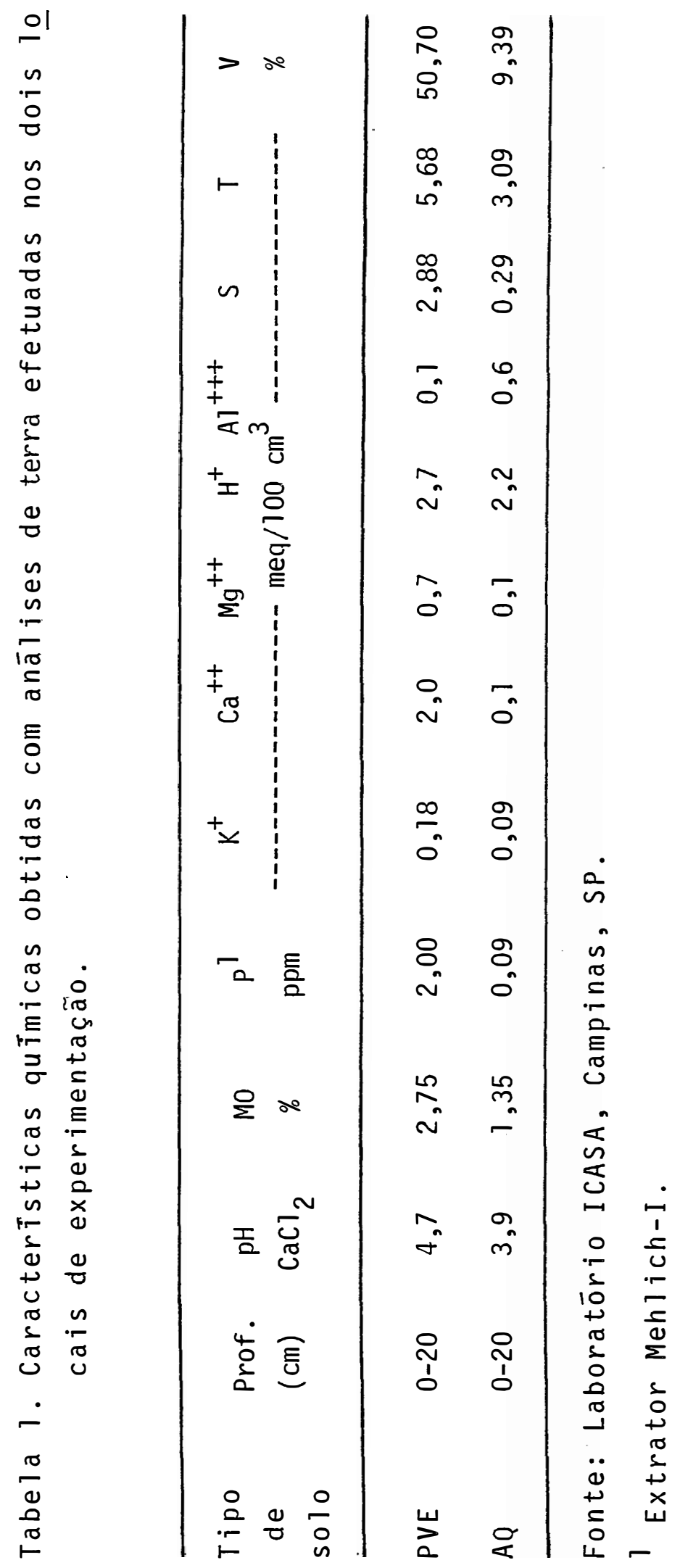




\subsubsection{Anāiọse fĩsica}

Amostras de terra coletadas em dezembro de 1985, juntamente com a caracterização morfológica, foram analisadas quíitio às caracte bela 2 .

Tabela 2. Características físicas obtidas com anāilises de ter ra efetuadas nos dois locais de experimentação.

Anālise mecānica (\%), NaOH $1 \mathrm{~N}$

Tipo de Prof.

solo $(\mathrm{cm})$

Areia

Grau

Floc.

$\%$.

\begin{tabular}{ccccccccccc}
\hline PVE & $0-16$ & 2,0 & 21,0 & 32,5 & 6,2 & 61,7 & 18,5 & 19,8 & 14,4 & 27 \\
& $16-33$ & 1,7 & 20,7 & 35,2 & 7,0 & 64,6 & 13,9 & 21,5 & 16,4 & 24 \\
& $33-85$ & 1,7 & 17,8 & 33,0 & 6,7 & 59,2 & 12,6 & 26,2 & 21,9 & 22 \\
& $85-148$ & 1,4 & 17,0 & 32,1 & 6,1 & 56,6 & 9,6 & 33,8 & 4,8 & 86 \\
& +148 & 1,8 & 19,1 & 32,7 & 6,5 & 60,1 & 8,7 & 31,2 & 2,7 & 91 \\
AQ & $0-17$ & 1,3 & 32,9 & 53,8 & 4,1 & 92,1 & 1,9 & 6,0 & 4,8 & 20 \\
& $17-42$ & 1,6 & 32,9 & 49,7 & 4,6 & 88,8 & 1,8 & 9,4 & 3,3 & 65 \\
& $42-128$ & 1,2 & 29,3 & 50,8 & 6,1 & 87,4 & 2,1 & 10,5 & 7,6 & 28 \\
& $128-160+$ & 1,3 & 28,0 & 45,8 & 7,8 & 82,9 & 3,3 & 13,8 & 6,7 & 51 \\
\hline
\end{tabular}

Fonte: Laboratōrio ICASA, Campinas, SP. 


\subsection{Métodos}

\subsubsection{Instalação dos ensaios}

os ensaios foram instalados nos dois locais em agos to de 1984 .

Foi utilizado o delineamento estatistico emblo bos ao acaso, com 8 tratamentos e 3 repetições. A especificação dos tratamentos nos dois locais de experimentação è apre sentada no Quadro 1.

Quadro 1. Nümero e especificação dos tratamentos para os dois locais de experimentação.

\begin{tabular}{ll}
1 & Clone $G-0245$ \\
2 & Clone $G-0246$ \\
3 & Clone G-0269 \\
4 & Clone G-0250 \\
5 & Clone G-0256 \\
6 & Clone G-0258 \\
7 & Clone G-0261 \\
8 & Clone G-0251 \\
\hline
\end{tabular}

As parcelas foram constituĩdas de 36 plantas, ao espaçamento $3 \times 3$ metros, das quais as 16 centrais ( 1 1 i- 
nha de bordadural foram consideradas nas avaliações silviculturais e somente 4 centrais (2 linhas de bordadura) foram ut $\mathbf{j}$. lizadas nas avaliações nutricionais.

\subsubsection{Area experimental}

- Area de uma parcela: $324 \mathrm{~m}^{2}$

- Area de um ensaio: $7.776 \mathrm{~m}^{2}$

- Area total: $15.552 \mathrm{~m}^{2}$

\subsubsection{Adubação e manutenção}

A adubação de plantio foi de $180 \mathrm{~g}$ de NPK da fōrmula 10-28-6, acrescido de $B$ e $Z n$, à base de $3 g$ de sulfato de zinco e $2 \mathrm{~g}$ de bōrax por planta. Essa adubação de arranque foi feita, nos dois locais, por ser utilizada, generalizadamente, nos plantios comerciais de eucaliptos em solos de cerrado na época da instalação do experimento.

\subsubsection{Coleta de dados}

Os ensaios foram avaliados no campo aos 18 e 54 meses de idade, coletando-se dados de crescimento em altura, sobrevivēncia de plantas, e diāmetro à altura do peito (DAP). O volume sōlido com casca por hectare, obtido através da förmula VSLCCHA $=\left(0,043151 \times\left(D^{2} \times A L T\right) * * 0,969196\right) / 100$, 
foi utilizado como parāmetro para avaliar a produção de madeira.

Na medição da altura das plantas ūteis das par celas o aparelho usado foi o Blume-Leiss e para determinação do DAP utilizou-se o compasso florestal.

\subsubsection{Anālise do solo}

Nos dois locais de experimentação foram amostrados os solos, nas trēs parcelas, nas profundidades de 0-15, 15-40 e $150 \mathrm{~cm}$, para se acompanhar a disponibilidade de nutrientes e a influēncia do cultivo de $E$. grandis nas caracteristicas quimicas de solo.

As anālises de amostras compostas de terra foram executadas no laboratōrio de Nutrição Mineral de Plantas, no Departamento de Química da ESALQ. As amostras foram secas ao ar e passadas por peneiras de malha de $2 \mathrm{~mm}$ de abertura. A determinação do pH foi feita em solução salina de cloreto de cālcio 0,01 M (SCHOFIELD e TAYLOR, 1955). O carbono orgānico foi determinado pela oxidação da matēria orgānica com solução sulfocrōmica e titulação do oxidante por iodometria (CA TANI e JACINTHO, 1974). O fósforo disponível e os cātions tro cāveis, potāssio, cālcio e magnésio, foram extraídos por uma mistura de resinas de cátions e ānions, tratada com solução de bicarbonato de sódio (RAIJ et alii, 1986). o aluminio trocável foi extraîdo com uma solução lN de cloreto de potássio e determinado por titullação (KAMPRATH, 1970). 
A soma de bases ( $S$ ) e a capacidade de troca ca tiōnica dos solos ( $T$ ) foram determinadas conforme as equações abaixo, sendo expressas em meq/100 $\mathrm{cm}^{3}$ de terra:

$$
\begin{aligned}
& S=C a+M g+K \\
& T=S+(H+A 1)
\end{aligned}
$$

A fração de T constituĩda pelas bases trocāveis foi expressa em porcentagem, atravēs da saturação de bases (V\%), calculada pela fórmula:

$$
\mathrm{V} \% \mathrm{~T} \times 100
$$

\subsubsection{Anālise quĩmica de plantas}

Amostras de folhas foram coletadas em dois periodos de crescimento, aos 12 e 56-57 meses de idades, objet vando conhecer o comportamento nutricional dos clones nos dois tipos de solo. A metodologia utilizada na coleta foi apresentada por BERTQLOTI (1986), sob orientação do Prof. Henrique Paulo Hag. Dezesseis ārvores centrais das parcelas de todos os tratamentos, nas 3 repetições, foram coletadas aos 12 meses de idade, e somente as árvores centrais da parcela foram coletadas aos 56-57 meses. As árvores foram amostradas no terço médio das copas, na direção dos 4 pontos cardeais, com as folhas no estádio de desenvolvimento recém-maduro ( 3 . ou 4. folha). Amostras compostas foram preparadas para cada tratamento com as amostras provenientes de cada ārvore. 
0 material recém-colhido foi colocado em sacos de papel, e enviado ao Laboratório de Nutrição Mineral de Plantas, no Departamento de Química da ESALQ, onde foram processadas as anālises de macro e micronutrientes.

o nitrogēnio foi determinado por titulação apōs passagem por microdestilador de Kjeldahl. O fósforo foi analisado em fotocolorỉmetro utilizando o método vanado-molibdato de amônio. As determinações de potássio, cálcio, magnēsio, enxofre, cobre, ferro, manganês e zinco foram feitas por fotometria de chama de emissão. o boro foi determinado atravēs da formação de um complexo colorido na reação do ácido bō rico com o reagente azometina $H$. Os métodos de anālise quīmica utilizados foram os recomendados por SARRUGE $e$ HAAG (1974) e BATAGLIA et alii (1983).

\subsubsection{Determinação da atividade da fosfatase ācida}

Para a determinação da atividade da fosfatase ácida (E.C. 3.1.3.2.), foram amostradas folhas medianas completamente expandidas do terço médio da copa de ārvores com 56-57 meses de idade, no periodo de abril a maio.

A atividade enzimática foi determinada através de técnica colorimétrica desenvolvida por BESSEY et alii (1946) e adaptada por BARRETT-LENNARD et alii (1982), com algumas modificações. 


\subsubsection{Extração da enzima e preparação do pó acetônico}

Aproximadamente $100 \mathrm{~g}$ (matēria fresca) de folhas foram homogeneizadas em $400 \mathrm{ml}$ de acetona fria (-150 C) du rante 60 segundos. Utilizando sucção, o homogenato foi filtrado atravēs de funil Buchner, com papel filtro Whatman nọ 3 . o resỉduo sob o papel filtro foi lavado värias vezes com volumes adicionais de acetona fria, e deixado secar à temperatú ra ambiente. A seguir, o residuo seco foi macerado em gra? com pistilo. O pó acetōnico foi armazenado em embalagens plāsticas e conservado à temperatura de $-150 \mathrm{C}$.

\subsubsection{Ensaio enzimático}

0 pó acetōnico foi suspendido em solução tampão acetato de sōdio - ācido acētico $(0,2 M ;$ pH 5,0$)$ à uma con centração de $10 \mathrm{mg} / \mathrm{ml}$ de tampão. Em seguida, a suspensão foi centrifugada a $7.000 \mathrm{~g}$, por 20 minutos, em centrīfuga refrigerada (4OC) e os tubos com o sobrenadante, imersos em gelo.

A atividade da fosfatase ācida foi determina da adicionando-se $1 \mathrm{ml}$ do sobrenadante à seguinte mistura de reação: tampão acetato de sōdio - ācido acético $(0,2 \mathrm{M}$, pH ajus tado para 5,0$)$, āgua destilada e p-nitrofenilfosfato saldissó dico (10m M). o volume final da mistura de reação foi de 6,0 ml. Em seguida, os tubos foram agitados levemente e incuba- 
dos à $300 \mathrm{C}$, durante 30 minutos. No final do tempo de incubação, a reação foi inteģrompida pela adição de $0,5 \mathrm{ml}$ de hidró xido de sōdio 2M. A a d'sorbância foi determinada a $405 \mathrm{~nm}$. Os brancos continham todos os reagentes, exceto o p-nitrofenilfos fato. A atividade enzimática foi expressa em umoles de p-nitrofenol formado por g de matéria fresca, por minuto.

\subsubsection{Anālise estatística}

\subsubsection{Anālise de variāncia individual}

A anālise de variância individual para os dados foi a usual (PIMENTEL GOMES, 1985).

0 modelo matemático empregado foi:

$$
x i j=m+b j+t i+e i j
$$

onde: $X i j=$ observação do tratamento $i$ no bloco $j$;

$m=$ média geral;

$b_{j}=$ efeito do bloco j $(j=1,2,3)$;

$t_{j}=$ efeito do tratamento $i(i=1,2, \ldots 8) ;$

$e_{i j}=$ erro experimental associado ao tratamento $i$ no bloco j.

o esquema da anālise de variāncia individual ē apresentado no Quadro 2. 
Quadro 2. Esquema de anālise de variāncia individual para as variāveis estudadas.

Causas da variação

G.L.

Blocos

2

Tratamentos

7

Erro

14

TOTAL

\subsubsection{Anāilise de variância conjunta}

A anālise de variância conjunta para os dois locais foi feita com as mēdias dos tratamentos (PIMENTEL GOMES, 1985). O erro utilizado nessa anālise fọi o erro médio entre os erros das anālises individuais

0 modelo matemático referente à anālise con-

junta foi:

$$
x_{i j k}=m+\ell_{j}+t_{i}+(t \ell) i j+b k(j)+e_{i j k}
$$

onde: $X_{i j k}=$ observação do tratamento $i$, no local $j$, no bloco $k$;

$\mathrm{m} \quad=$ mëdia geral;

$\ell_{j}=$ efeito do local $j(j=1,2)$;

$t_{j}=$ efeito do tratamento $i(i=1,2, \ldots 8)$;

$(t \ell)_{i j}=$ efeito da interação do tratamento $i$ com o local $j$;

$\operatorname{bk}(j)=$ efeito do bloco $k$ dentro do local $j(k=1,2,3)$;

$e_{i j k}=$ erro experimental. 


\section{A anāilise conjunta foi estruturada como mostra}

o Quadro 3 .

Quadro 3. Esquema da añ̄i ise de variância conjunta.

G.L.

Blocos dentro Locais

Locais (L)

Tratamentos

$L \times T$

Erro Mēdio

0 coeficiente de correlação de spearman $\left(r_{S}\right)$ foi utilizado para a comparação dos valores dos "rankings" das caracteristicas estudadas (SNEDECOR \& COCHRAN, 1974; KAGEYAMA, 1977 ).

o rs foi obtido pela seguinte fórmula:

$$
r_{s}=1-\frac{6 \sum_{i} d_{i}^{2}}{n\left(n^{2}-1\right)}
$$

onde: $d_{j}=$ diferença entre as posições para cada tratamento; $n=$ nūmero de diferenças. 
0 teste de significância dos valores de $r_{s}$ ob tidos, foi realizado atravēs do teste t, pela förmula:

$$
t=\frac{r_{s} \sqrt{(n-2)}}{1-r_{s}^{2}}
$$

onde: $r_{S}=$ coeficiente de correlação de Spearman; $\mathrm{n}=$ nümero de dados em cada variāvel. 


\section{RESULTADOS E DISCUSSÃO}

4.1. Resultado das anālises quỉmicas dos solos

\subsubsection{Resultados obtidos nos ensaios aos 54 meses de idade}

As anālises quīmicas dos solos, Podzōlico Vermelho-Escuro (PVE) e Areia Quartzosa (AQ), visaram o acompanhamento da fertilidade dos 2 locais, após 54 meses de cultivo com E. grandis. Os resultados das anālises químicas estão apresentados na Tabela 3.

Analisando os resultados, constata-se que os 2 solos apresentam acidez elevada, baixos teores de nutrientes e valores muito baixos de saturação de bases, que são limitações comuns na maioria dos solos dos cerrados (ADAMOLI et alii, $1986)$.

0 valor de $\mathrm{pH}$ em $\mathrm{CaCl}_{2}$ para os dois solos reve lou-se extremamente baixo pela interpretação de RAIJ \& QUAGGIO (1982), que considera limites minimos à partir de pH igual a 4,3 . 


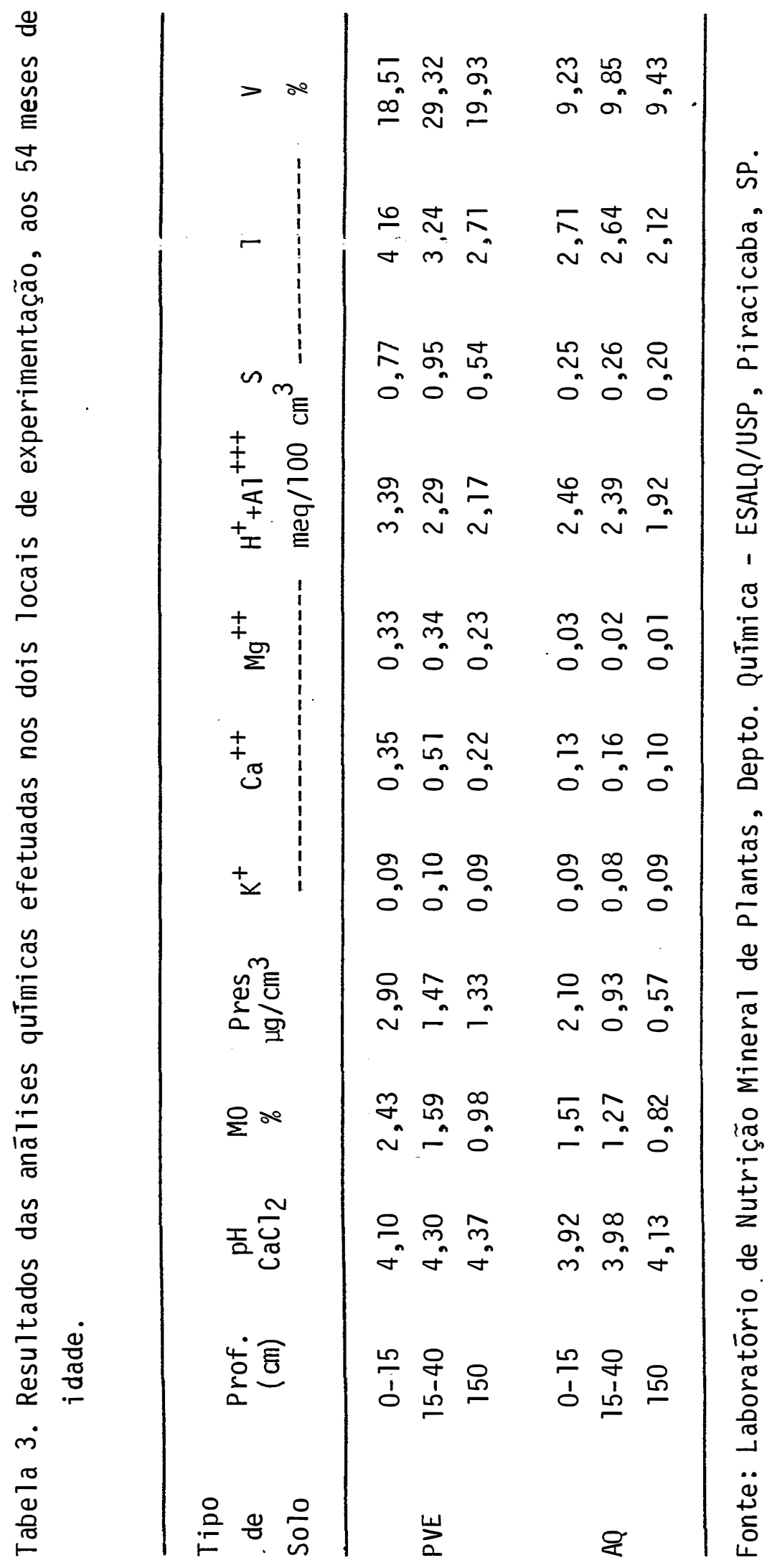


Observa-se uma tendēncia de elevação de pH em profundidade, para os dois solos, como esperado. No PVE, a partir da camada $15-40 \mathrm{~cm}$, verificou-se o limite minimo de aci dez $(\mathrm{pH} 4,3)$, enquanto em $A Q$, até $150 \mathrm{~cm}$ de profundidade, não foi encontrado esse limite.

Os teores de matéria orgānica, conforme diz LOPES (1984), podem ser considerados médios entre 1,5 a 3,8\%. Até 15-40 cm, o PVE apresentou valores médios de matéria orgānica, que foram superiores ao teor médio encontrado entre $0-15 \mathrm{~cm}$ na $A Q$.

A distribuição da matéria orgānica no perfil dos dois solos mostra uma redução com a profundidade, decrescendo bruscamente da camada superficial para a camada abaixo no PVE. De acordo com MELLo et alii (1985), a maior quantida de de matéria orgānica na superfície de solos de florestas de ve-se a contribuição da serrapilheira mais do que a das raízes, embora uma proporção razoável destas se localizem superficialmente.

Nota-se que os teores de fósforo, potāssio, cāi cio e magnésio trocáveis estão extremamente deficientes nos 2 solos, não havendo grandes alterações com o aumento da profun didade do perfil. No solo AQ foi encontrado teores de Ca e Mg trocáveis bastante inferiores àqueles no PVE, que refletiram no baixo valor da capacidade de troca cationica.

Encontrou-se que para os 2 solos analisados, pre domināncia de acidez potencial $\left(\mathrm{H}^{+}+\mathrm{Al}^{+++}\right)$no complexo de troca, com valores muito baixos de saturação de bases (V), in 
dicando que a parte de T ocupada pelas bases trocáveis, atingiu $22,6 \%$ para PVE e 9,5\% para AQ.

A baixa capacidade de troca catiōnica observada nos 2 solos até a profundidade de $150 \mathrm{~cm}$, exceção feita a camáca superficial do PVE que mostra um nivel um pouco superior a 4 meq/100 $\mathrm{cm}^{3}$, é indicativa de um grande potencial para lixiviação de cátions (LOPES, 1984).

\subsubsection{Influēncia do cultivo de $E$. grandis nas caracteristicas quimicas dos solos}

O efeito do cultivo de E. grandis na acidez do solo, após 54 meses do plantio, foi obtido comparando-se os dados da camada superficial das Tabelas 1 (päg. 35) e 3. Cons tatou-se redução do pH, ou seja, aumento da acidez para PVE e, manutenção do grau de acidez para AQ.

Nos dois solos observou-se uma tendência à redução dos teores de matéria orgānica com o cultivo de eucalip tos, embora estes teores sejam considerados mēdios. No entanto, conforme evidencia LEPSCH (1980), seria importante se con siderar as quantidades de matéria orgānica do folhedo, pois estas devem ser bem menores em $A Q$ que em PVE devido ao menor teor de argila do primeiro solo (Tabela 2, päg. 36). Quanto maior o teor de argila, maior será capacidade do solo em reter humus. 
Apesar dos solos estudados serem originalmente de média a baixa fertilidade, respectivamente para PVE e $A Q$, não houve efeito de aumentar os teores de matēria orgānica e quantidade de nutrientes nos horizontes superficiais. Na AQ os niveis de fertilidade e acidez se mantiveram, enquanto no PVE houve decrēscimo de $\mathrm{pH}$, de $\mathrm{K}^{+}$e $\mathrm{Mg}^{++}$, sendo a redução destas bases de $50 \%$, e uma redução de $82,5 \%$ nos teores de $\mathrm{Ca}^{++}$. Portanto, constata-se que o cálcio foi o elemento mais absorvido pelos eucaliptos cultivados no PVE.

\subsection{Efeito de locais no comportamento de clones de} E. grandis aos 18 e 54 meses de idade

Os resultados de crescimento em altura, DAP, por centagem média de sobrevivēncia e volume sólido com casca por hectare, nos dois locais - solo Podzólico Vermelho-Escuro (PVE) e solo Areia Quartzosa ( $A Q)$, para as idades de 18 e 54 meses são apresentados, respectivamente, nas Tabelas 4 e 5 .

\subsubsection{Sobrevivēncia}

Os dados de médias de sobrevivēncia aos 18 meses de idade revelaram valores altos, generalizadamente para todos os clones na $A Q$, e valores pouco menores no PVE. A média geral do ensaio na $A Q$ foi de $94,27 \%$, com valor de $89,58 \%$ 


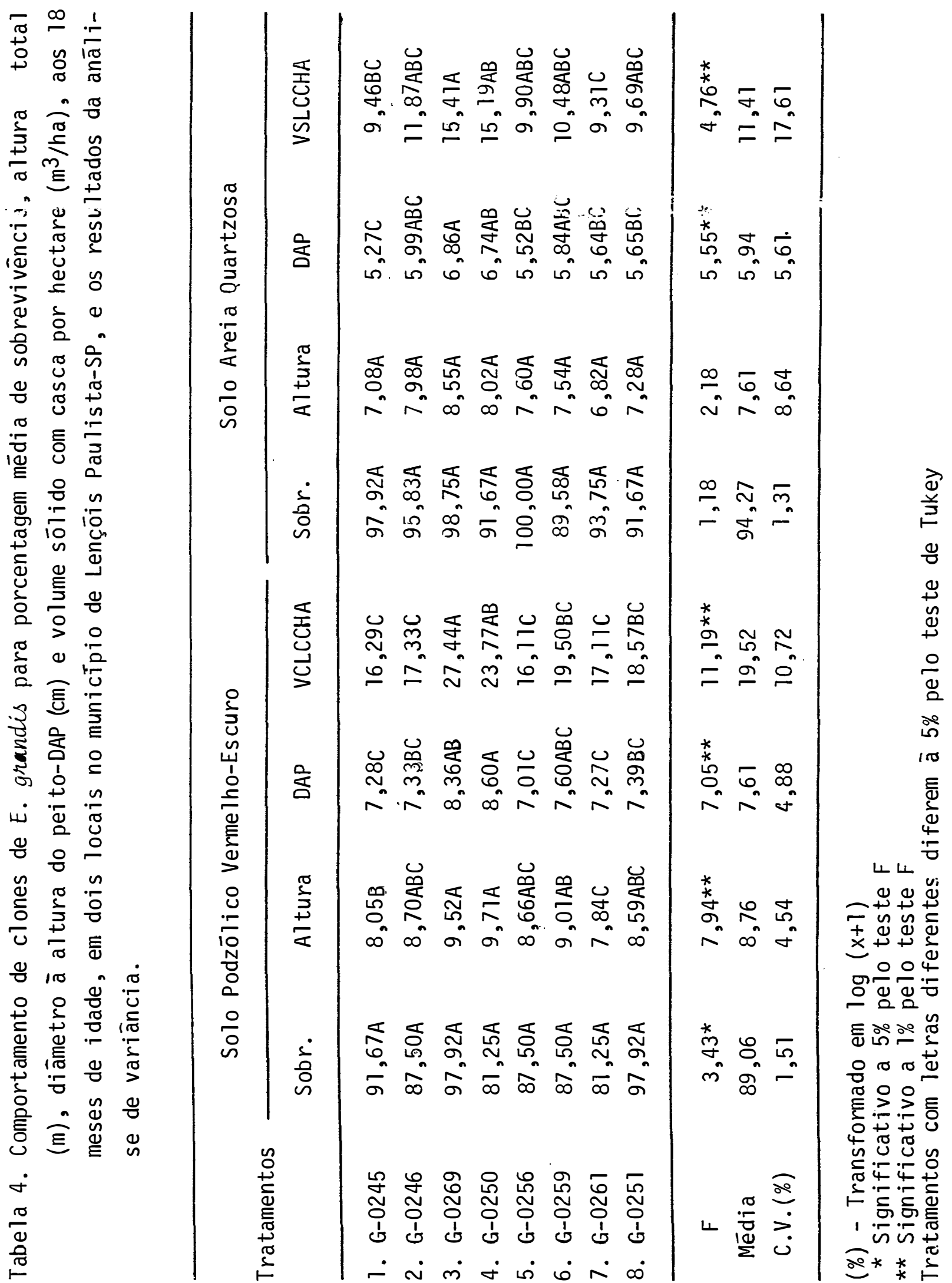




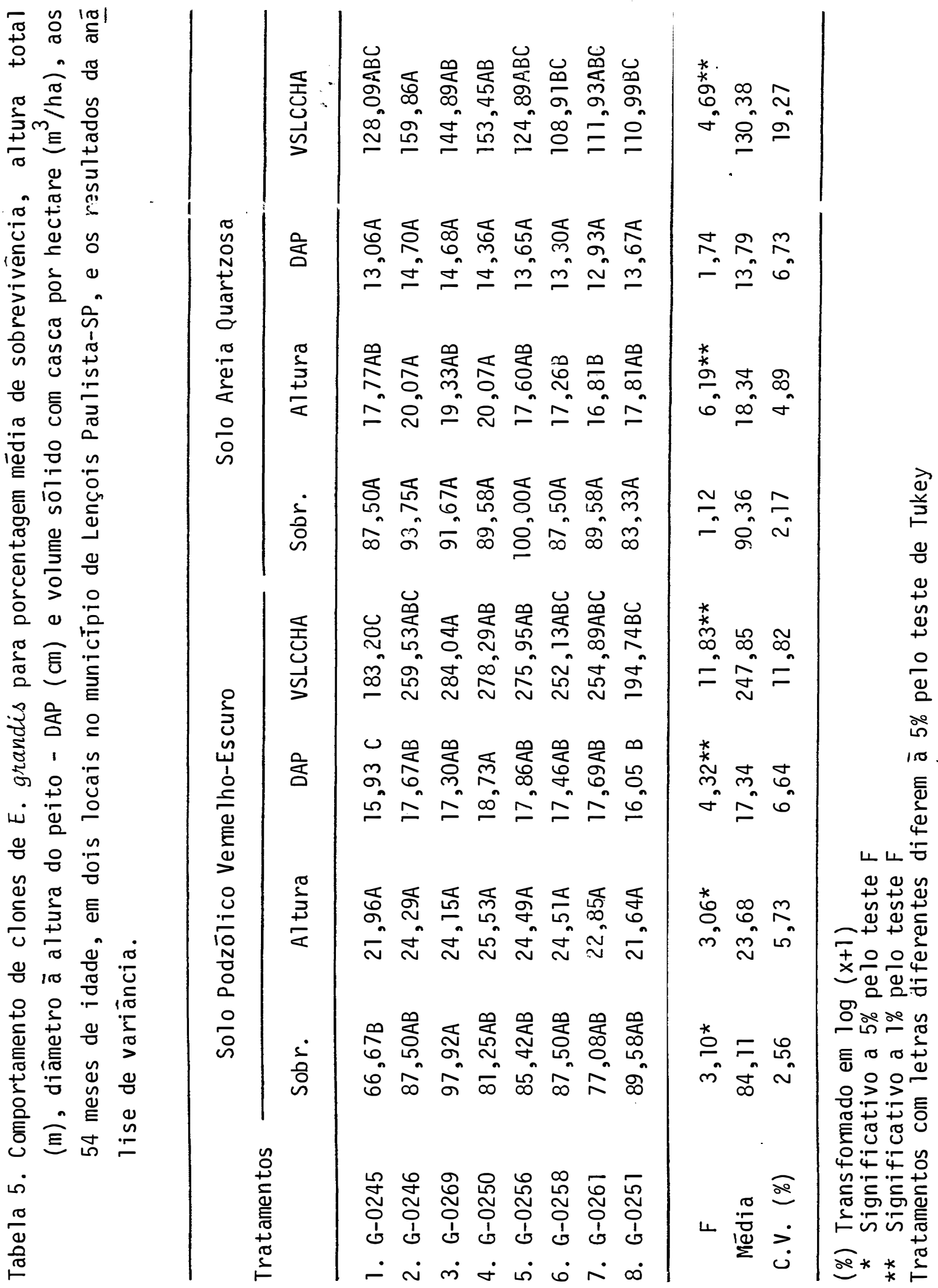


para o clone de pior sobrevivēncia. No solo PVE, aos 18 meses de idade, a média geral de sobrevivēncia foi de 89,06\%, com o clone de pior sobrevivēncia apresentando valor de $81,25 \%$.

Aos 54 meses ae idade, a média de sobrevivência na AQ foi de $90,36 \%$, com pequena redução com relação aos dados de 18 meses de idade, com valor de $83,33 \%$ para o clone de pior sobrevivência. No solo PVE, aos 54 meses de idade, também houve redução da sobrevivēncia com relação aos dados de 18 meses de idade, a média geral foi de $84,11 \%$, com o clone pior apresentando o valor de $66,27 \%$.

O pior clone no PVE, aos 54 meses de idade, com relação a sobrevivēncia foi o G-0245. Esse clone aos 18 meses de idade apresentou alta sobrevivēncia, com valor de $91,67 \%$, e posteriormente aos 54 meses mostrou uma redução de $25,00 \%$. Um aspecto a ser considerado, observando-se os dados de médias por parcela verifica-se que o clone G-0245 apresentou baixa sobrevivēncia em uma das parcelas, com valor de $56,25 \%$, enquanto a média das outras parcelas foi de $71,88 \%$. E importante mencionar que o G-0245 foi o clone que apresentou a maior porcentagem de enraizamento das estacas provenientes da árvore matriz, em torno de $84 \%$. A redução na sobrevivência foi observada apōs a ocorrēncia de ventos muito fortes; assim, su gere-se que o tombamento das ārvores esteja relacionado a qua lidade do sistema radicular, que deve ser bastante superficial. 
A anālise de variāncia aplicada aos dados de mēdias das parcelas, transformados em $\log (x+1)$, aos 18 e 54 meses de idade, revelou significāncia (5\%) para os valores de F obtidos para o ensaio no PVE e não significāncia para o ensaio na $A Q$.

A comparação entre médias do teste Tukey, para a porcentagem mēdia de sobrevivência, revelou diferenças significativas entre clones para o ensaio no PVE aos 54 meses de idade.

\subsubsection{Altura total}

A anālise de variāncia aplicada aos dados de médias de parcelas para altura total aos 18 meses revelou valores de $F$ significativos ao nivel de $1 \%$ para o ensaio no PVE e valores não significativos para o ensaio na $A Q$, revelando a existência de variação genētica entre clones no PVE.

A amplitude observada entre os clones para altura total aos 18 meses de idade no PVE, mostra valores de 9,7l a 7,84 m, enquanto no ensaio na $A Q$ os valores foram de 8,55 a $6,82 \mathrm{~m}$. Os melhores clones para a caracteristica alt ra de planta foram o G-0245 e G-0269 no PVE, e na AQ foi o G-0269. O pior clone, para os dois ensaios, foi o G-0261.

Os coeficientes de variação para os ensaios fọ ram, respectivamente no PVE e na $A Q$, valores de $4,54 \%$ $8,64 \%$, evidenciando que na $A Q$ o valor foi $90,31 \%$ superior àque- 
le no PVE. Esses valores revelam-se baixos, indicando

uma boa precisão para o experimento em discussão, possibilitando a detecção de variações entre clones.

0 teste Tukey para comparação entre médias mos tra diterenças estatisticas entre clones no PVE, mas não no ensaio na $A Q$. Os clones G-0250 e G-0269 diferiram ao nível de $5 \%$ de significāncia do clone de pior crescimento (G-0261).

Aos 54 meses de idade, a anālise de variāncia aplicada aos dados de altura total revelou valores de $F$ significativos ao nível de $5 \%$ no ensaio no PVE e significativo ao nỉvel: de $1 \%$ no ensaio na $A Q$, modificando os resultados obtidos aos 18 meses de idade. A variação genētica entre clones é afirmada nessa idade para os dois ensaios, revelando a importāncia dessa característica.

Ainda, pela anālise de variāncia, obteve-secoe ficiente de variação equivalente entre os ensaios, com valores de 5,73 e 4,89, respectivamente no solo PVE e na $A Q$.

Embora a ordem de classificação dos principais clones não tenha sofrido grandes alterações, houve um aumento na amplitude de variação entre os tratamentos, superior à duas vezes àquela amplitude mostrada aos 18 meses. Os melhores crescimentos aos 54 meses foram apresentados pelos clones G0250 e G-0258 no PVE, e pelos clones G-0246 e G-0250 na AQ. Ainda os melhores clones no PVE foram superiores àquele de pior crescimento em $84,76 \%$, enquanto os melhores clones na $A Q$ foram $83,76 \%$ superiores àquele clone de pior crescimento, va- 
lores maiores dos obtidos aos 18 meses, equivalentes a $80,74 \%$ e $61,64 \%$, respectivamente no PVE e na AQ. Esses fatos contribuem com a idéia de que extrapolações dos resultados para ida des adultas devem ser feitas com muito cuidado.

A comparaçáo entre mëdias pelo teste Tukey para altura total, revelou diferenças daquela comparação aos 18 meses, não mostrando diferenças entre os clones no PVE, enquanto na $A Q$ houve diferença entre os tratamentos ao nível de $5 \%$.

\subsubsection{DAP}

Os dados de crescimento em DAP aos 18 meses de idade mostram resultados semelhantes obtidos para os ensaios no PVE e na AQ. A anālise de variāncia para os dados médios de parcelas revelou valores para f significativos ao nivel de $1 \%$.

A amplitude observada entre os clones para DAP aos 18 meses de idade, mostra no PVE valores de 8,60 a 7,01 $\mathrm{cm}$, enquanto no ensaio na $A Q$ os valores foram de 6,86 a 5,27 cm. Os melhores clones para o crescimento em DAP foram G0250 e G-0269, respectivamente para PVE e AQ. Com relação aos piores clones, respectivamente no PVE e na $A Q$, os tratamentos com menores valores foram G-0256 e G-0245.

Os coeficientes de variação para os ensaios fo ram, respectivamente no PVE e na $A Q$, valores de 4,38 e 5,61, 
evidenciando semelhança entre os locais. Esses valores revelam-se baixos, o que indica uma boa precisão para o experimento, possibilitando a detecção de variações genéticas entre clones.

0 teste Tukey revelou diferençüs significativas entre clones. O clone G-0250 no ensaio em solo PVE diferiu ao nível de $5 \%$ dos trēs clones de pior crescimento (G-0256, G-0261 e G-0245), enquanto os outros clones não diferiram sịg nificativamente entre si. No ensaio em $A Q$, o melhor clone (G-0269) diferiu ao nivel de $5 \%$ do clone de pior crescimento (G-0245), e os outros clones não diferiram significantemente en tre si.

Os dados de médias de crescimento em DAP, para o ensaio no PVE, aos 54 meses de idade, foram similares aos obtidos para 18 meses. Por outro lado, no ensaio na AQ os da dos médios de DAP foram discordantes daqueles obtidos aos 18 meses. A anālise de variāncia para os dados dessa caracterís tica revelam valores para o F significativos ao nível de $1 \%$ no PVE, mas não significativos na $A Q$. A existência de variações genēticas entre clones foi marcada no ensaio em solo PVE, nas duas idades estudadas; embora, essas variações não tenham ocorrido no ensaio em. $A Q$.

Ainda, pela anālise de variāncia, obteve - se coeficiente de variação para a característica em questão de $6,64 \%$ no PVE e $6,73 \%$ na $A Q$, valores equivalentes que mostram uma boa precisão para o experimento. 
Cabe a observação que o melhor clone no PVE pa ra a caracteristica crescimento em DAP, aos 18 e 54 meses de idade, foi o G-0250 que, nesse ensaio foi o melhor clone para a caracteristica altura total. Para o ensaio na $A Q$ o clone G-0269 foi o meinor tratamento para as características de cres cimento em altura em DAP, aos 18 meses de idade, enquanto aos 54 meses o clone G-0246 foi o melhor para essas duas caracte rísticas.

A amplitude observada entre os clones para DAP aos 54 meses de idade, mostra no PVE valores de 18,73 a 19,53 $\mathrm{cm}$, enquanto no ensaio na $A Q$ os valores foram de 14,50 a 12,93 $\mathrm{cm}$. Esses valores comparados àqueles aos 18 meses de idade permitem observar que a amplitude entre clones aumentou em $76,10 \%$ no solo PVE, e na $A Q$ o aumento foi apenas de $11,32 \%$.

A comparação entre mēdias pelo teste Tukey para DAP aos 54 meses de idade, revelou novamente diferenças significativas entre clones no PVE, e a não existēncia de diferenças significativas entre clones na $A Q$. No solo PVE - clone G-0250, de melhor crescimento em DAP, diferiu ao nível de $5 \%$ de significância dos dois clones de pior crescimento em DAP, ou seja, do G-0245 e G-0251. Por outro lado, no ensaio sob $A Q$, o clone de melhor crescimento em DAP, isto é, o G-0246, não diferiu estatisticamente do G-0261, que foi o clone de pior crescimento. 
60.

\subsubsection{Volume sōlido com casca por hectare}

Para crescimento em volume sōlido com casca por hectare, aos 18 meses de idade, a anālise de variāncia dos da dos revela valores para o f significativos ao nivel de $1 \%$, equivalentes ao crescimento em altura e em DAP no solo PVE, e para crescimento em DAP na $A Q$. Esses valores mostram novamen te a existēncia de variações genéticas ao nível de clones.

A amplitude de variação entre clones para cres cimento em volume, aos 18 meses de idade, mostra clones de 27,44 a $17,11 \mathrm{~m}^{3} / \mathrm{ha}$ no PVE, e valores de 15,41 a $9,31 \mathrm{~m}^{3} / \mathrm{ha}$ na $A Q$. A superioridade do clone G-0269 para crescimento em volume sólido com casca por hectare foi observada nos dois so los, relativamente aos clones de pior volume mostra valor superior de $37,65 \%$ e $39,58 \%$, respectivamente no PVE e na $A Q$, o que evidencia a magnitude das diferenças entre clones.

0 teste Tukey para comparação de mēdias de clo nes para volume sōlido com casca por hectare, aos 18 meses, revelou a existēncia de diferenças significativas. 0 clone G-0269, de maior sobrevivência e segundo melhor crescimento em altura e DAP no solo PVE, difere ao nīvel de $5 \%$ de significân cia dos piores clones G-0256, G-0245, G-0261 e G-0241, e tambēm difere dos clones G-0251 e G-0258. Assim, só não mostra diferença significativa do clone G-0250, que apresenta a melhor colocação para as características de crescimento em altu ra e em DAP, mas com a pior sobrevivēncia. No ensaio sob $A Q$, 
- clone G-0269 também mostra o melhor crescimento em volume e para altura e DAP, mas revela menor valor de sobrevivēncia. Os clones G-0269 e G-0250, segundo colocados para a caracteristi ca em questão, respectivamente para $P V E$ e $A Q$, não diferiram au nivel de $5 \%$ do primeiro colocado em cáda iucai. No solo PVE, O G-0269 diferiu significativamente (5\%) dos clones G0256, G-0245, G-0261 e G-0246. Por outro lado, na AQ o segun do melhor tratamento, isto é, o G-0250 diferiu significativamente ao nivel de $5 \%$ do clone G-0261.

0 coeficiente de variação para o ensaio em AQ foi $64,27 \%$ superior àquele em PVE, com valores de $17,61 \%$ e $10,72 \%$, respectivamente.

os dados de médias de volume sōlido com casca por hectare aos 54 meses de idade foram similares aos obtidos para os 18 meses. A anālise de variāncia, também para essa idade, revelou valores para o F altamente significativos, mos trando a existēncia de variações genēticas entre clones para volume.

Ainda, pela anālise de variāncia, obteve-se coe ficiente de variação para a caracterīstica em questão de $11,82 \%$ para o ensaio no PVE, e de $19,27 \%$ para $A Q$, valores que mostram uma boa precisão para o experimento. Para ensaios florestais esses coeficientes de variação revelam-se baixos, possibilitando a detecção de variações entre clones.

A amplitude observada entre os clones para volume sōlido com casca por hectare mostra a tendēncia de aumen to da magnitude com o avanço da idade. 
Cabe a observação de que os dados de médias pa ra crescimento em volume aos 54 meses mostram a superiorida de da média dos clones em PVE comparativamente a média na $A Q$. 0 melhor clone para a característica volume sólido com casca por hectare nu soiu PVE, isto é, o G-0269, mostra um valor de $56,28 \%$ superior àquele do melhor clone no ensaio da $A Q$, que é o $G-0246$.

0 teste Tukey para comparação de médias de clo nes para crescimento em volume aos 54 meses de idade revelou a existēncia de diferenças significativas para os ensaios no PVE e na AQ. No solo PVE, o clone G-0269 difere ao nivel de $5 \%$ de significāncia nos dois clones de pior comportamento (G-0245 e G-0251). O segundo melhor clone no solo PVE (G-0250) difere ao nível de $5 \%$ de significāncia do clone de pior comportamento (G-0245), mas não difere dos outros clones em estudo. O ensaio na $A Q$ mostra que o melhor clone, isto é, - G-0246, difere ao nível de $5 \%$ de significāncia dos dois clo nes de pior crescimento em volume (G-0258 e G-0251).

\subsection{Concentração de nutrientes em folhas de clones de} E. grandis

As concentrações de macro e micronutrientes en contrados nas folhas da parte intermediāria da copa, são apre sentadas nas Tabelas 6 e 7 para a idade de 12 meses, e Tabelas 8 e 9 para a idade de 56-57 meses. 


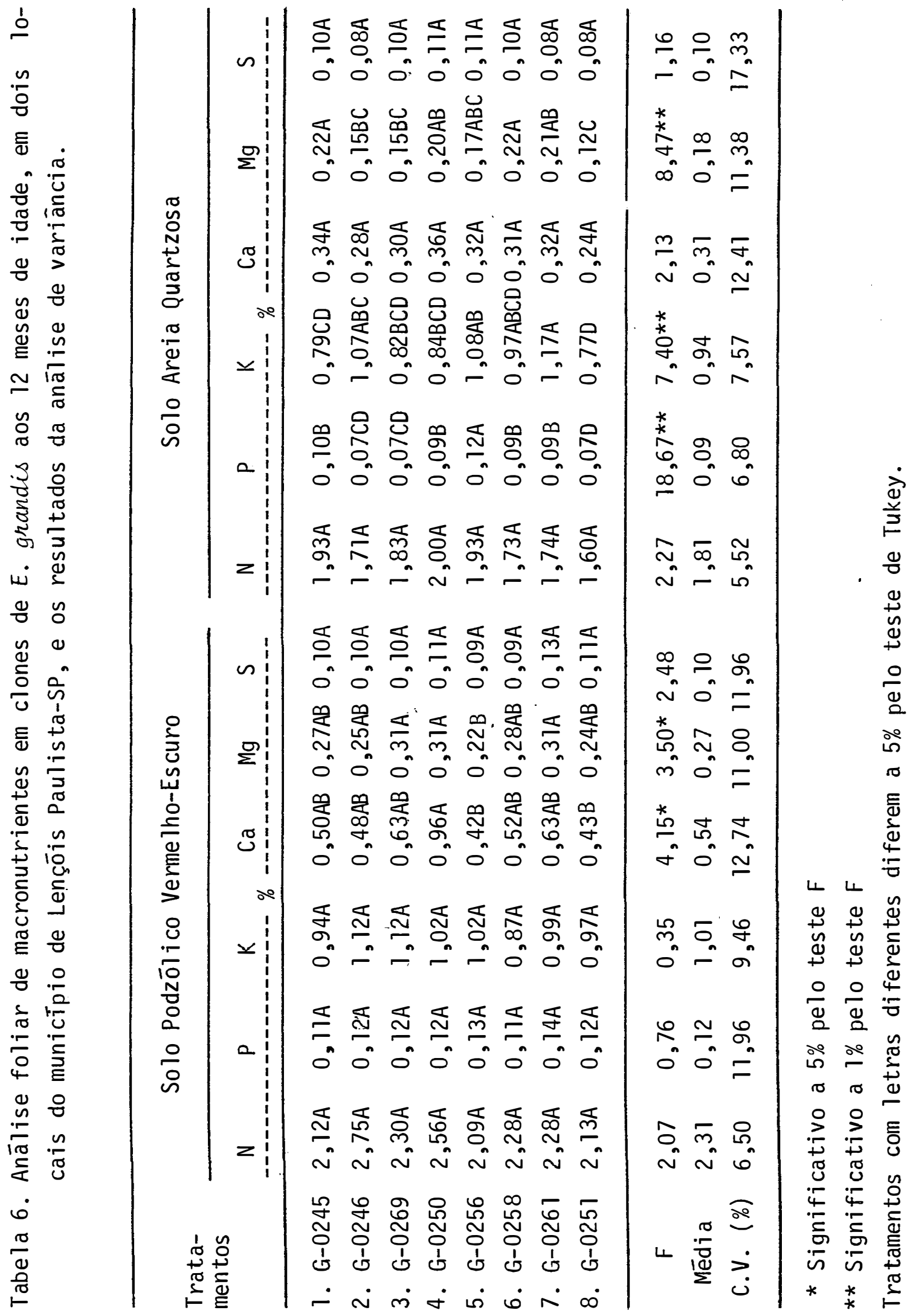




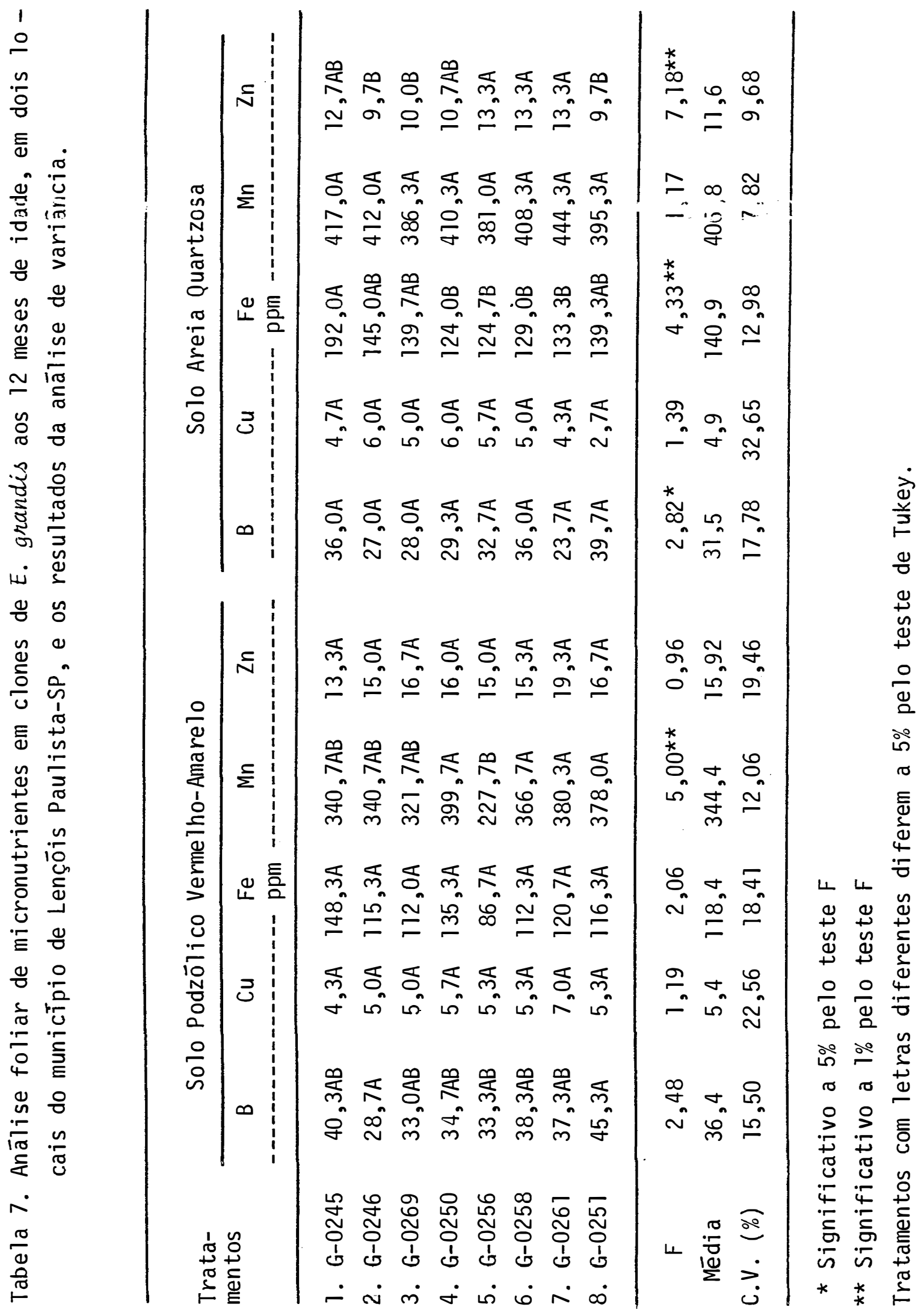




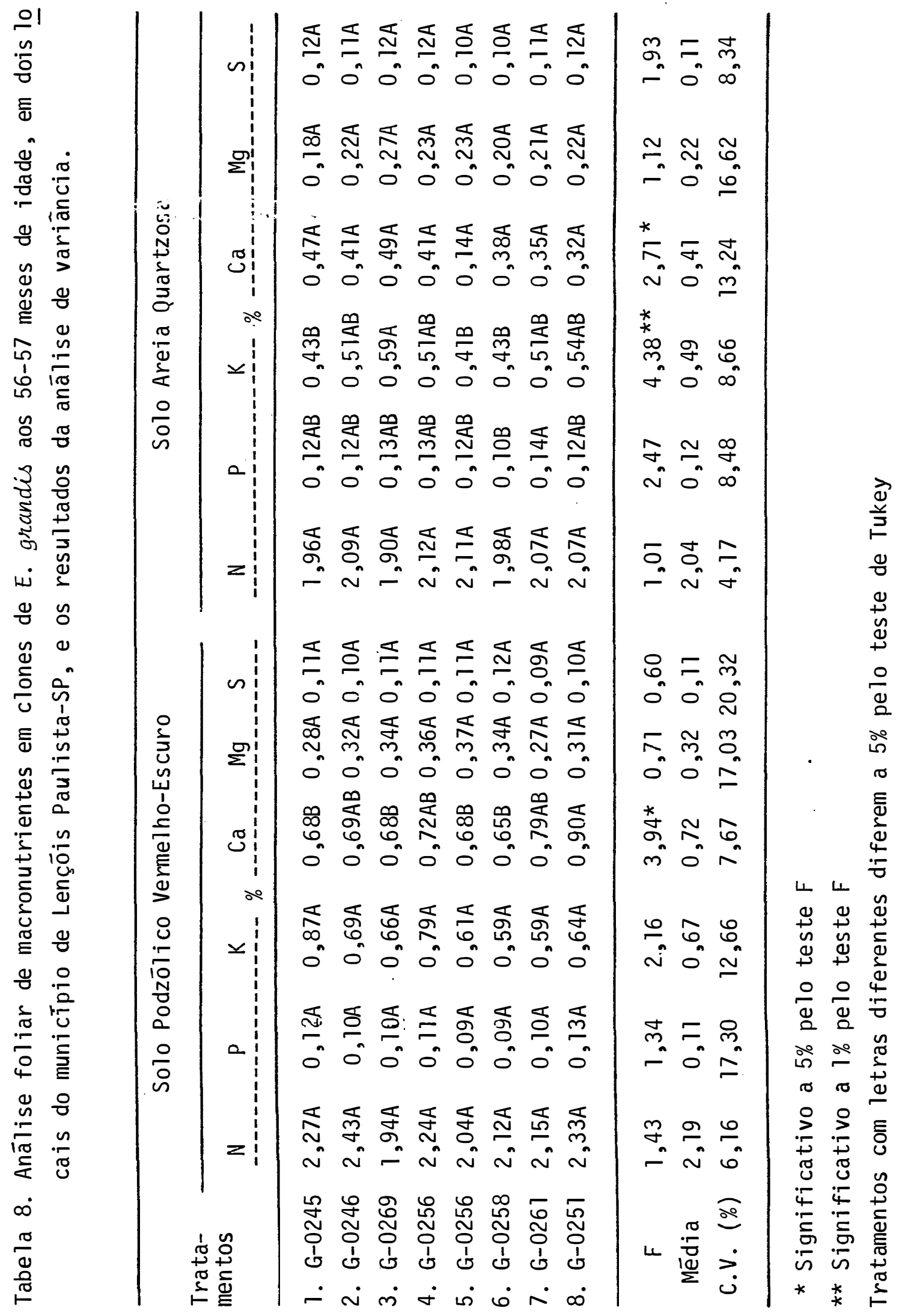




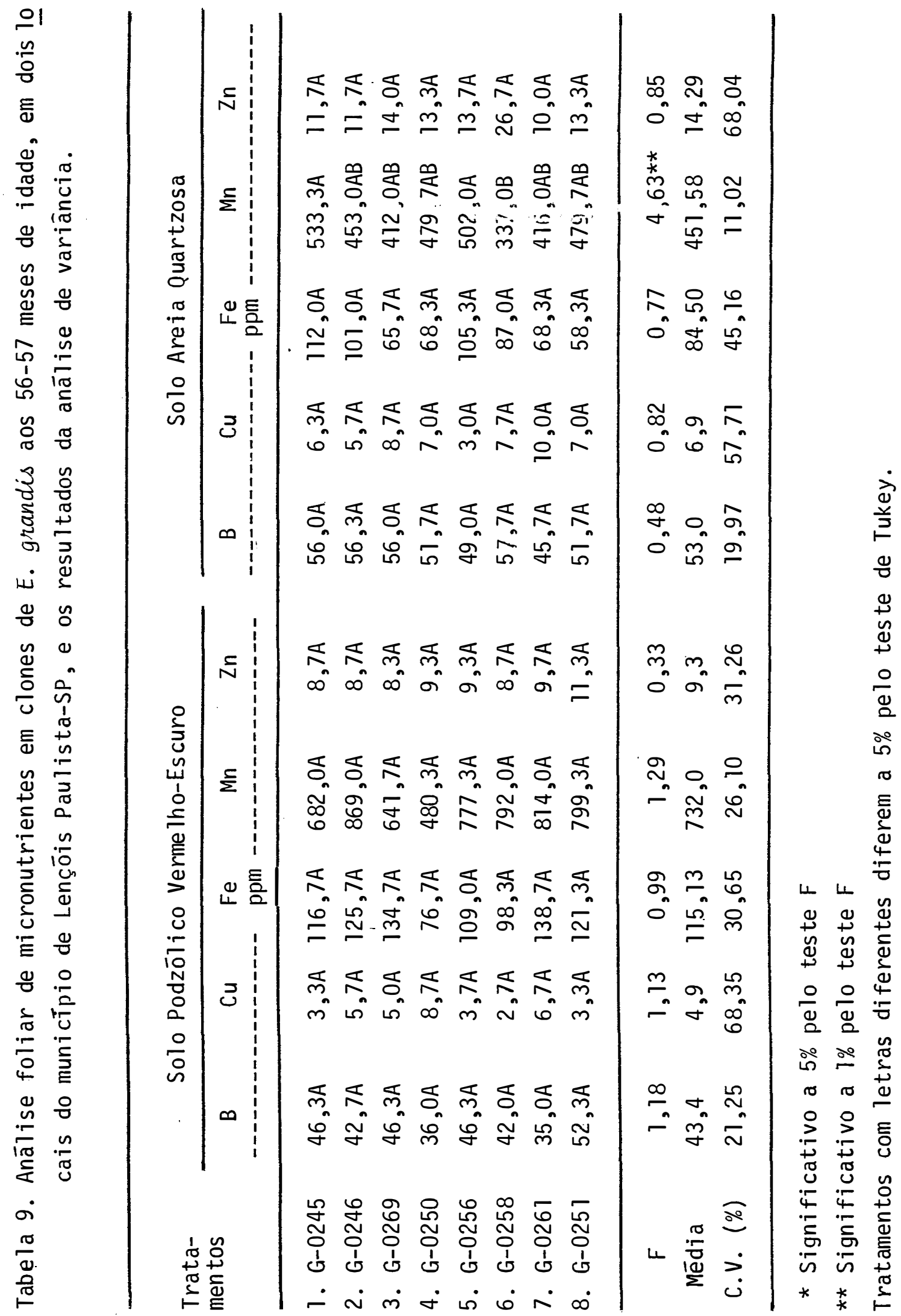




\subsubsection{Macronutrientes}

A anāilise de variāncia aplicada aos dados de mēdias, transformados em $\log (x+1)$ para a concentração de maeronutriences, dos 12 meses de idade, revesoll yatores signiti cativos ao nível de $5 \%$ para Ca e Mg no PVE, e valores signifi cativos ao nível de $1 \%$ para $P, K$ e Mg na $A Q$, mostrando a exis tēncia de variação genētica entre clones para as concentrações desses nutrientes.

Ainda, pela anālise de variāncia obteve-se coe ficiente de variação, respectivamente no PVE e na $A Q$, mostran do valores de 6,50 e $5,52 \%$ para $N, 11,96$ e $6,8 \%$ para P, 9,46 e 7,57\% para K, 12,74 e 12,41\% para Ca, 11,00 e $11,38 \%$ para Mg, 11,96 e $17,38 \%$ para S. Esses valores são considerados ba 1 xos para ensaios florestais, o que indica uma boa precisão pa ra o experimento em questão.

A amplitude observada entre os clones mostra a magnitude da variação observada para as concentrações de ma cronutrientes.

Para a concentração de $N$, a faixa de variação foi de 2,75 a $2,09 \%$ no ensaio sob PVE, enquanto na $A Q$ os valo res foram de 2,00 a $1,60 \%$. O melhor clone (G-0246), isto é, aquele com maior concentração de N, no PVE, apresenta um valor $31,52 \%$ superior daquele clone com menor concentração de $N$ (G-0256). Na AQ, o melhor clone (G-0250) mostra valor $25 \%$ superior ao pior clone (G-0251), que tambēm mostrou o menor crescimento em altura. 
A amplitude entre os clones para a concentração de $P$ mostra valores de 0,14 a $0,11 \%$ no $P V E$, e na $A Q$ valores de 0,12 a 0,07\%. O clone que apresentou a maior concentração de P no PVE foi o G-0261, por outro lado este clone mostrou o menor crescimenco eri altura. As menores concentrações de P, no PVE, foram encontradas nos clones G-0245 e G-0258, sendo que esses clones apresentaram, respectivamente, a sētima e terceira colocação para a caracteristica crescimento em altura. No ensaio sob AQ o clone que mostrou maior concentração de $P$ foi o G-0256, e a queles com menor concentração foram o G-0246, G-0269 e G-0258. Os très clones de pior colocação para $P$ apresentaram valores baixos, e assim, com tendēncia a deficiēncia em P.

Os valores da concentração de $K$ nos clones sob PVE foram de 1,12 a $0,87 \%$, e na $A Q$ a amplitude foi de 1,17 a 0,77\%. Os melhores colocados no PVE foram os clones G-0246 e G-0269, enquanto na $A Q$ foi 0 G-0261. Os piores colocados foram O G-0258 e G-0251, respectivamente no PVE e na AQ que mo traram valores de $28,74 \%$ e $51,95 \%$ inferiores aos melhores colocados.

Para a concentração de Ca, a amplitude foi de 0,69 a 0,42\% no ensaio sob PVE, e na $A Q$ de 0,36 a 0,24\%. A maior concentração de Ca foi mostrada pelo clone G-0250 nos dois locais, que também apresentou a primeira e segunda colo cação para a característica altura, respectivamente nos solos PVE e AQ. Por outro lado, a menor concentração de Ca foi mos 
trada pelo clone G-0251 na $A Q$ e no PVE, e G-0256, tambēm, no PVE. Os piores colocados apresentaram valores de $64,29 \%$ e $50 \%$ inferiores àqueles do melhor clone (G-0250) nos ensaios sob PVE e AQ, respectivamente.

A amplitude entre us ilones para a concentração de Mg mostra valores de 0,31 a 0,22\% no PVE, e de 0,22 a a $0,12 \%$ na A?. As maiores concentrações de Mg no PVE foram encontradas nos clones G-0269, G-0250 e G-0261, enquanto a menor concentração foi mostrada pelo G-0256. No ensaio sob AQ, os primeiros colocados foram G-0245 e G-0258, e os ūitimos colocados foram G-0246 e G-0269. A diferença entre os maio res e menores valores no PVE e na AQ foi, respectivamente, de $40,91 \%$ e $83,33 \%$.

Para a concentração de S, os valores no PVE e AQ foram, respectivamente, de 0,13 a $0,09 \%$ e de 0,11 a $0,08 \%$. 0 melhor colocado no PVE (G-0261) revelou um valor 44,44\% superior àquele dos piores colocados (G-0256 e G-0258). Na AQ os melhores colocados (G-0250 e G-0256) mostram um valor $37,50 \%$ superior àquele dos piores clones (G-0246, G-0261 e G-0251).

0 teste de Tukey para a comparação entre mëdias, para concentrações de macronutrientes revelou diferenças significantes ao nível de $5 \%$ entre clones para Ca e Mg no ensaio sob PVE, e para $P, K, C a$ e Mg na $A Q$.

Aos 56-57 meses de idade, a anālise de variància dos dados revela,para as concentrações de macronutrientes, valores para o F significativos ao nível de $5 \%$ para Ca no PVE 
e na $A Q$, e valor para $F$ significativo ao nível de $1 \%$ para $K$ na $A Q$, mostrando novamente a existēncia de variações genéticas ao nivel de clones para Ca no PVE e para K, na $A Q$.

Os coeficientes de variação para o ensaio mostram valores uin pouco superiores aos 56-57 meses daguches aos 12 meses para $P, K$, Mg e $S$ no PVE, e N, P, K, Ca e Mg na AQ. Esses valores continuam serido baixos para ensaios florestais, o que indica uma boa precisão para o experimento.

A comparação entre médias pelo teste Tukey revelou diferenças significativas entre clones para Ca no PVE e para $P$ e $K$ na $A Q$, semelhante àquela na primeira idade, com exceção do Mg, que não mostrou significāncia aos 56-57 meses. No ensaio sob PVE para concentração de Ca, o clone G-0251 diferiu ao nỉvel de $5 \%$ de significância dos clones G-0245, G-0269, G-0256 e G-0258, e outros clones não dife riram entre si. Na $A Q$, para a concentração de $P$ o clone G-0261 diferiu ao nîvel de $5 \%$ de significância do G-0258, e os outros clones não diferiram entre si, e para a concentração de K o clone G-0269 diferiu ao nível de $5 \%$ de significāncia dos clones G-0245, G-0256 e G-0258, enquanto os outros clones não diferiram entre si.

Com a idade, houve uma diminuição na amplitude de variação entre os tratamentos, o que pode ser verifica do pelos valores de $F$ das anālises de variāncias para as duas idades. Para o $N$, os valores foram de 2,43 a $1,94 \%$ no PVE, e de 2,12 a $1,90 \%$ na $A Q$. Para O $P$, os valores foram de 0,13 a 0,09\% no PVE, e de 0,14 a $0,10 \%$ na $A Q$. Para o $K$, os valores 
foram de 0,87 a 0,59\% no PVE, e de 0,59 a 0,41\% na AQ. Para - Ca, os valores foram de 0,90 a 0,65\% no PVE, e de 0,49 a $0,32 \%$ na $A Q$. Para o $\mathrm{Mg}$, os valores foram de 0,37 a $0,27 \%$ no PVE, e de 0,27 a $0,18 \%$ na $A Q$. Para O $S$, os valores foram de 0,13 a $0,09 \%$ in P!E, e $I \equiv U, 1<$ a $0,10 \%$ na $A Q$.

\subsubsection{Micronutrientes}

A anālise de variância aplicada aos dados de médias para as concentrações de micronutrientes, aos 12 meses de idade, revelou valores altamente significativos para Mn no PVE e para Fe e Zn na $A Q$, e valor significativo ao nivel de $5 \%$ para $B$ na $A Q$, mostrando a existência de variações genēticas entre clones.

Os coeficientes de variação para o ensaio no PVE foram de $15,50 \%$ para B, 22,56\% para Cu, 18,41\% para Fe, e $12,06 \%$ para Mn e 19,46\% para Zn. Na AQ, os valores dos coe ficientes de variação foram de $17,78 \%$ para B, 32,65\% para Cu, $12,98 \%$ para $\mathrm{Fe}, 7,82 \%$ para $\mathrm{Mn}$ e $9,68 \%$ para $\mathrm{Zn}$. Esses valores revelam-se bastante superiores aqueles encontrados em macronutrientes, embora sejam considerados baixos para ensaios flo restais, com exceção do valor de Cu na $A Q$.

0 teste Tukey para comparações entre médias re velou diferenças significativas entre clones para $B$ e $M n$ no PVE, e para Fe e Zn na $A Q$. O clone G-0251, com maior concentração de B no PVE, diferiu ao nỉvel de $5 \%$ de significância do 
G-0246, enquanto os outros clones não diferiram entre si. Os primeiros colocados para Mn no ensaio sob PVE (G-0250, G-0261, G-0251 e G-0258) diferiram ao nível de $5 \%$ de significância do G-0256. Na AQ, para a concentração de Fe, o primeiro colocadu (G-0245) diferiu ao nível ue 5\% de sigritiliancia dos clones G-0261, G-0258, G-0256 e G-0250, e para a concentração de $Z n$, os primeiros colocados (G-0256, G-0258 e G-0261) dife riram ao nível de $5 \%$ de significāncia dos clones G-0246, G0251 e G-0269.

As amplitudes observadas entre os clones para as concentrações de micronutrientes mostram a magnitude das variações observadas.

Os clones de maiores concentrações de B mostram-se $57,84 \%$ e $67,51 \%$ superiores aos clones de menores concentrações, respectivamente nos ensaios sob PVE e AQ.

Os melhores clones para concentração de Cu mos tram-se $62,79 \%$ e $122,22 \%$ superiores aos clones de menores con centrações, respectivamente no PVE e $A Q$.

Para a concentração de Fe, os primeiros coloca dos, respectivamente no PVE e AQ, mostraram-se $71,05 \%$ e $54,84 \%$ superiores àqueles ūitimos colocados.

Os primeiros colocados para a concentração de Mn, no PVE e na AQ, mostraram-se $75,54 \%$ e $54,84 \%$ superiores aos clones de menores concentrações.

Para a concentração de $\mathrm{Zn}$, os clones com maiores valores, respectivamente no PVE e AQ, mostraram-se $75,54 \%$ e $16,61 \%$ superiores aos clones com menores valores. 
Aos 56-57 meses de idade, as anālises de variāncia para micronutrientes revelaram valores de $F$ não significantes, bastante inferiores àqueles obtidos aos 12 meses de idade, com exceção da concentração de Mn que mostrou valor de $\vec{i}$ untamente significativo na $A Q$, enquanto ná prilliéîâa idade não mostrava significāncia entre os clones.

Ainda, pelias anālises de variāncias, obteve-se os coeficientes de variação para as concentrações de micronutrientes, com valores bastante superiores àqueles obtidos aos 12 meses, que foram, respectivamente no PVE e $A Q, 21,25 \%$ e $19,27 \%$ para B, $68,35 \%$ e $57,71 \%$ para Cu, $30,65 \%$ e $45,16 \%$ para Fe, $26,10 \%$ e $11,02 \%$ para $\mathrm{Mn}$, e $31,26 \%$ e $68,04 \%$ para $\mathrm{Zn}$.

A comparação entre mēdias pelo teste Tukey, pa ra as concentrações de micronutrientes aos 56-57 meses de ida de, revelou diferenças significativas ao nivel de $5 \%$ entre os clones para a concentração de Mn no ensaio sob AQ. Os clones com maiores valores de $M n$ (G-0245 e G-0256) diferiram signifi cativamente do clone com menor valor de $M n(G-0258)$. Os outros clones não diferiram significativamente entre si.

A amplitude de variação entre os clones aumentou ou diminuiu com a idade dependendo do nutriente analisa do.

Para o B, houve redução da amplitude de variação para os ensaios no PVE e AQ, com valores entre os primeiros e últimos colocados de $49,43 \%$ e $26,26 \%$, respectivamente. Para o Cu, houve um grande aumento da amplitu- 
de de variação no PVE e AQ, com valores entre os clones de maior e menor concentração de $222,22 \%$ e $233,33 \%$, respectivamen te.

Para o Fe, também houve aumento da amplitude de variação, com vạures eritre o primeiro e ūltimo colocados da ordem de $80,83 \%$ no PVE, e de $70,47 \%$ na $A Q$.

Para o Mn, houve redução da amplitude entre os clones no PVE, mostrando o primeiro colocado valor de $69,48 \%$ superior do ūltimo colocado, por outro lado, no ensaio sob AQ houve aumento da amplitude de variação, com superioridade do primeiro colocado em relação ao ūltimo colocado de $58,25 \%$.

Tambēm foi observado para a concentração de $\mathrm{Zn}$ comportamento diferente entre os clones no PVE e na $A Q$. No primeiro solo houve redução da amplitude de variação entre os clones com a idade, com superioridade do primeiro colocado em relação aos $\bar{u} 1$ timos de $36,15 \%$; jā no ensaio sob AQ houve aumento da amplitude de variação entre os clones, com valor $167 \%$ superior do primeiro colocado em relação ao ūltimo.

\subsubsection{Relações entre nutrientes}

Os resultados das relações $N / P, N / K, N / S, P / K$ e Ca/Mg, obtidos com os dados de médias das concentrações individuais desses nutrientes, nas duas idades avaliadas, são apresentados nas TabeTas 10 e 11 . 


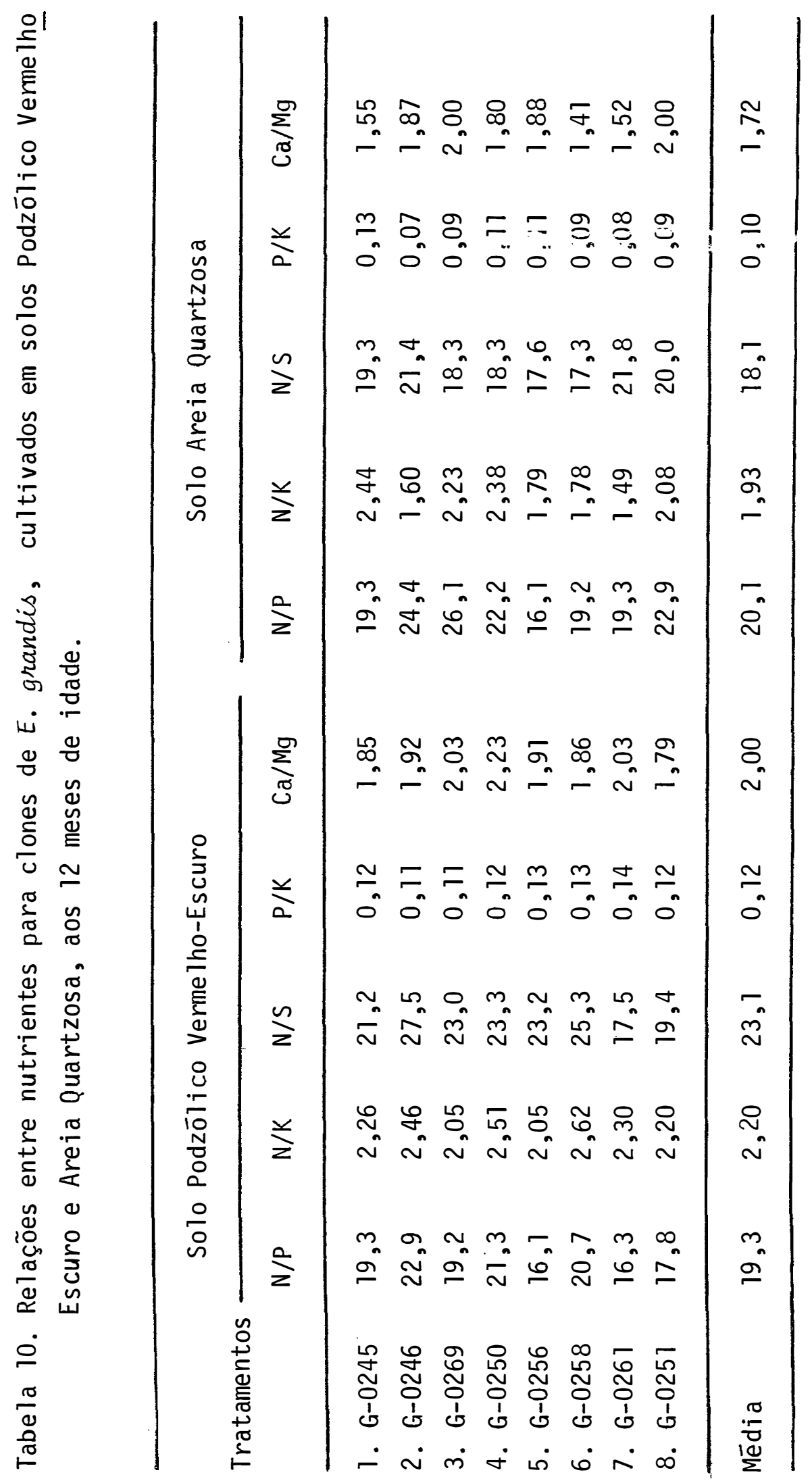




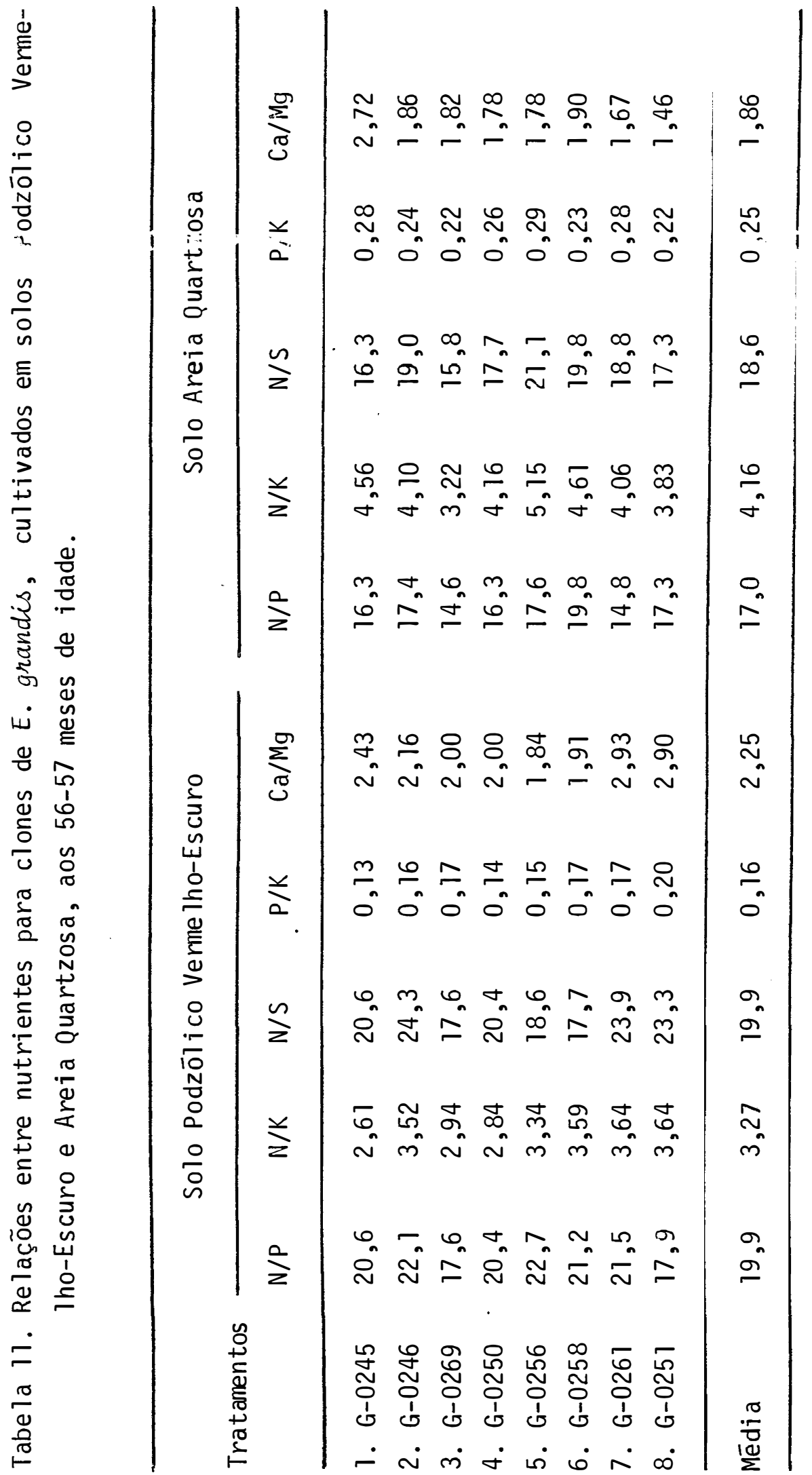


As amplitudes de variação entre clones para a relação N/P, aos 12 meses de idade, mostram valores de 22,9 a 16,1 no ensaio sob PVE, e valores de 26,1 a 16,1 na AQ. No PVE, O G-0246, quarto colocado em altura, foi o clone que apre sentou maior valor da ijif, "uue è bastante superior ao valor considerado ótimo por SCHONAU (1983), isto é, 13,00, enquanto o G-0256, quinto colocado em altura, com o menor valor de N/P, apresentou valor mais próximo āquele considerado ótimo, assim, fica evidente o desbalanço entre $N$ e P, provocado pelas baixas concentrações de P. No ensaio na AQ, o G-0269,pr $\underline{j}$ meiro colocado em altura, mostrou um al to valor dessa relação, o que possivelmente, irā comprometer o crescimento desse clone em idades posteriores; a menor relação foi mostrada pelo G-0256, quarto colocado em altura, com valor mais próximo ao ótimo.

Aos 54 meses de idade, houve uma redução das amplitudes de variação entre clones nos solos PVE e AQ, com va lores de 22,7 a 17,6 e de 19,8 a 14,6 , respectivamente. maior valor de N/P foi mostrado pelo G-0256 no PVE, terceiro colocado em altura, enquanto o menor valor, foi do clone G-0269, quinto colocado em altura. No ensaio sob AQ, O G0258, segundo colocado em altura, foi o clone que apresentou o maior valor de N/P, enquanto O G-0269, terceiro colocado em altura, mostrou o menor valor de $N / P$, sendo este bastante prōximo ao considerado ōtimo. 
As amplitudes de variação entre clones para a relação N/K, aos 12 meses de idade, mostram valores de 2,62 a 2,05 no PVE, e valores de 2,44 a 1,49 na $A Q$. De acordo com SCHONAU (1983) o valor dessa relação deve ser próximo a 3,0, portanto, todos os clones apresentam deseyulitiorio entre $N$ e $K$, devido às baixas concentrações de $K$ nas folhas. No solo PVE, o G-0258, terceiro colocado em altura, mostrou o maior valor de $N / K$, que é próximo àquele considerado ótimo, enquanto, os menores valores foram mostrados pelos clones G-0269 e G-0256, segundo e quinto colocados em altura, respectivamente. Na AQ, o clone G-0245, sétimo colocado em altura, mostrou o maior valor de $N / K$, que é inferior àquele considerado ótimo, enquanto o G-0261, ūitimo colocado em altura, apresentou o mais baixo valor de $N / K$.

Aos 54 meses de idade, houve um aumento

das amplitudes de variação entre clones nos dois locais de experimentação, com valores de 3,64 a 2,61 no PVE, e de 5,15 a 3,22 na $A Q$. Esse aumento da relação $N / K$ está relacionado com a tendēncia de-aumento das concentrações de $K$ com a idade. No solo PVE, os clones G-0261 e G-0251, respectivamente, sexto e oitavo colocados em altura, mostraram os maiores valores de $N / K$, sendo esses valores considerados acima do ótimo, enquanto, o clone G-0245, sétimo colocado em altura, mostrou o menor valor. Noisolo $A Q$, o maior valor da relação N/K foi mostrado pelo clone G-0256, sexto colocado em altura, com valor muito superior àquele considerado ótimo, evidenciando o 
desequilíbrio desses nutrientes, enquanto o menor teor, mais próximo ao ótimo, foi mostrado pelo G-0269, terceiro colocado em altura.

Para a relação N/S, as amplitudes de variação entre ciunies, aus 12 meses de idade, mostram valores de 27,5 a 17,5 no PVE, e de 21,8 a 17,3 na $A Q$. 0 valor considerado ótimo por FURTINI NETO (1988) está ao redor de 12 para Eucalyptus grandis, assim, todos os clones estão com desequilíbrios devido às baixas concentrações de $S$, com possivel alterações na sintese de proteinas. No solo PVE, O G-0246, quarto colo cado em altura, mostra o maior valor de N/S, enquanto, 0 G0261 , último colocado em altura, mostra o menor valor, que ainda está muito acima do valor considerado ótimo. No ensaio na $A Q$, o clone G-0245, sétimo colocado em altura, mostrou o maior valor de N/S, e O G-0258, quinto colocado em altura, apresentou o menor valor, que ainda está acima do valor ótimo para N/S.

Aos 54 meses de idade, houve uma redução da am plitude de variação entre clones no PVE, mas na $A Q$, houve aumento dessa amplitude. No solo PVE, o maior valor da relação N/S foi mostrado pelo clone G-0246, quarto colocado em altura, enquanto, o menor valor foi mostrado pelo G-0269, quinto colocado em altura, mas esse valor ainda é bem maior que àque le considerado ótimo.

Para a relação $P / K$, as amplitudes de variação entre clones, aos 12 meses de idade, mostram valores de 0,14 
a 0,1l para o ensaio no PVE, e valores de 0,13 a 0,07 para 0 ensaio na $A Q$. 0 valor considerado ótimo por SCHONAU (1983) está ao redor de 0,23 , assim, podemos visualizar que todos os clones mostram valores bastante aquém do considerado ótimo, devido às baixas cuncentrag̃ose de $\dot{r}$ e $\ddot{i}$ ras folhas. No solo PVE, o maior valor de P/K foi mostrado pelo clone G-0261, oitavo colocado em altura, que é bastante abaixo daquele valor considerado ótimo, enquanto os clones G-0246 e G-0269, respec tivamente o quarto e segundo colocados em altura, mostraramos menores valores de $P / K$.

Aos 54 meses de idade, houve aumento das ampl $\underline{i}$ tudes de variação entre clones para $P / K$, embora esse aumento tenha sido pequeno no ensaio na AQ. No PVE, o clone G-0251, oitavo colocado em altura, apresentou o maior valor de $P / K$, enquanto o menor valor foi mostrado pelo G-0245, sétimo colocado em altura. No ensaio na $A Q$, o maior valor foi mostrado pelo G-0256, sexto colocado em altura, enquanto, o menor valor foi mostrado pelos clones G-0269 e G-0251, respectivamente, terceiro e quarto colocados em altura.

As amplitudes de variação entre clones para a relação Ca/Mg, aos 12 meses de idade, mostram valores de 2,23 e 1,79 no ensaio no PVE, e valores de 2,00 a 1,41 na AQ. o valor considerado ótimo por SCHONAU (1983) está ao redor de 3,3 , assim, pode-se verificar que os valores encontrados estão bastante abaixo daquele considerado ótimo, evidenciando o desequitíbrio entre esses nutrientes nos clones estudados, 
devidoàs baixas concentrações de $\mathrm{Ca}$ e Mg nas folhas desses clo nes. Para o ensaio no PVE, o clone G-0250, primeiro colocado em altura, mostrou o maior valor de $\mathrm{Ca} / \mathrm{Mg}$, embora abaixo daquele considerado ótimo, e o clone G-0251, sexto colocado em altura, apresentou o menor valor. No sulo Ầ, o G-0269 e - G-0251, primeiro e sétimo colocados em altura, foram os clo nes que mostraram os maiores valores de $\mathrm{Ca} / \mathrm{Mg}$, embora também muito inferiores a valor ótimo, e o clone G-0258, quinto colocado em altura, mostrou o menor valor dessa relação.

Aos 54 meses de idade, houve aumento das amplitudes de variação para a relação Ca/mg, como era o esperado, pois existe uma tendēncia de maior concentração de Ca e Mg nas folhas com o avanço da idade. No entanto, esse aumento não modificou a situação de desequilíbrio entre Ca e Mg pa ra todos os clones nos dois locais de experimentação. No PVE, o clone G-0261, sexto colocado em altura, mostrou o maior valor para a relação $\mathrm{Ca} / \mathrm{Mg}$, enquanto o G-0251, sétimo colocado em altura, mostrou o menor valor. No ensaio na AQ, o G-0245, quinto colocado em altura, apresentou o maior valor de $\mathrm{Ca} / \mathrm{Mg}$, e o G-0251, quarto colocado em altura, foi o clone com menor valor. 
4.4. Atividade da fosfatase àcida em clones de E. grandis, aos 56-57 meses de idade

\subsubsection{Resultados da atividade da fosfatase ācida}

Os resultados da atividade da fosfatase ácida, em folhas recém maduras são apresentados na Tabela 12 .

os dados de médias da atividade da fosfatase ácida revelaram valores superiores no PVE, comparativamente à queles no ensaio na $A Q$, sendo respectivamente, 1,511 e 1,376 umol p-nitrofenol.g.matēria fresca-1. min $^{-1}$.

A amplitude observada entre as parcelas do ensaio sob AQ para a atividade da fosfatase ácida mostra valores de 0,34 a 2,88 $\mu$ mol p-nitrofenol.g.matēria fresca-1.min ${ }^{-1}$, enquanto entre as parcelas do ensaio no PVE os valores foram de 0,83 a 2,40 umol p-nitrofenol.g.matēria fresca-1.min ${ }^{-1}$. Es ses valores estão dentro da faixa encontrada em vārios tecidos de Eucaluptus diversicolor que foi de 0,5 a 6,5 umol p-ni trofenol.g.matēria fresca-1. $\mathrm{min}^{-1}$ (O'CONNELL \& GROVE, 1985).

A análise de variāncia para a atividade da fos fatase ācida revela valores para F significativos ao nível de $5 \%$ no ensaio sob PVE, e não significativo no ensaio sob AQ. Assim, esses valores mostram a existēncia de variações genēticas ao nivel de clones somente no PVE. 
83.

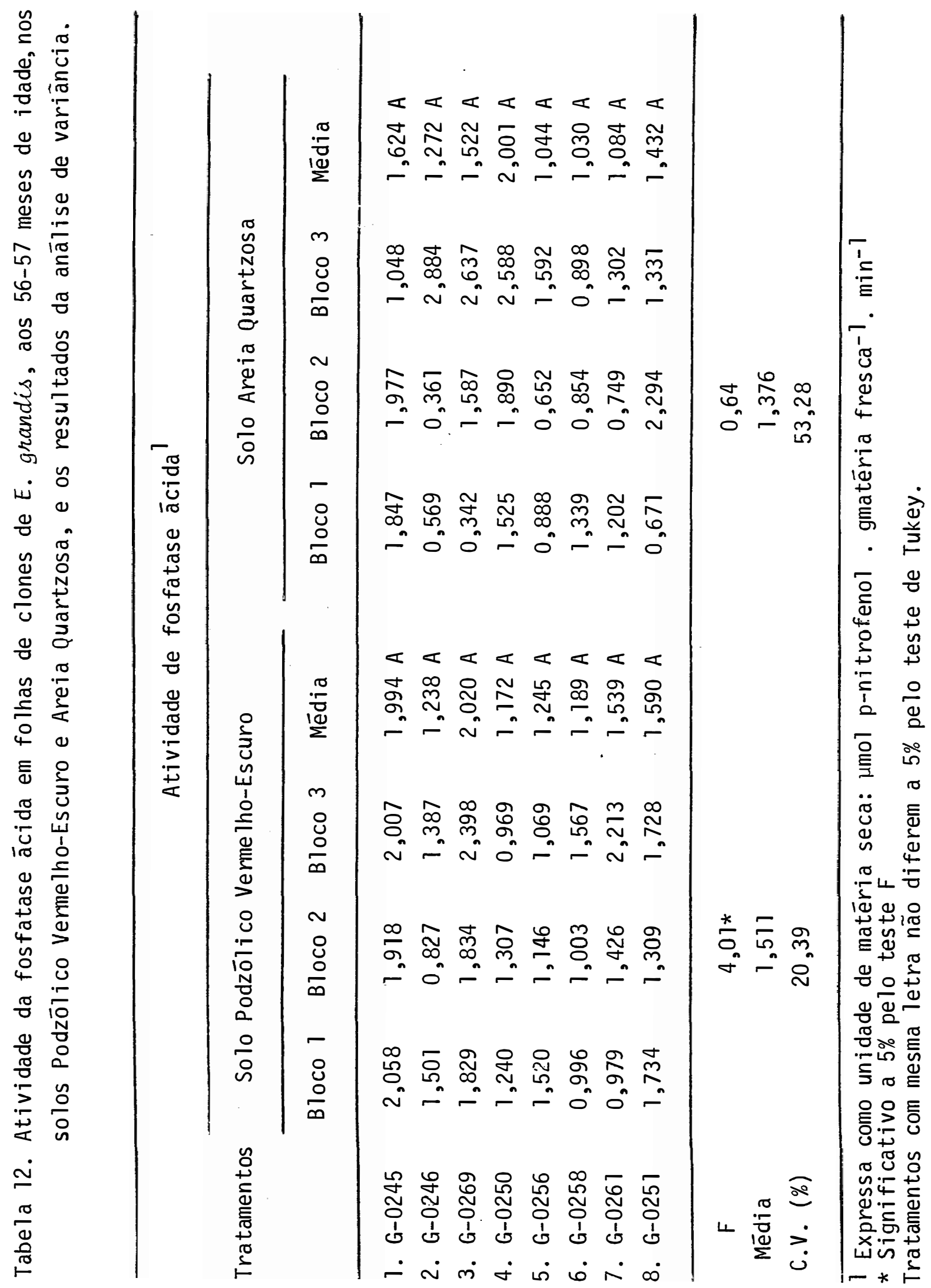


0 coeficiente de variação para os ensaios foram, respectivamente no PVE e AQ, valores de $20,39 \%$ e $53,28 \%$. Nos ensaios florestais o valor do coeficiente de variação no PVE é considerado bom, enquanto na $A Q$ o valor mostra que houve menor precisão, impossibilitando a detecçãu ùe var iaçòes genéticas entre clones. A grande diferença entre os valores dos coeficientes de variação pode ser explicada pelo maior tempo de coleta das folhas na $A Q$, devido à condições ambientais des favorāveis, com ocorrēncia de ventos fortes que prejudicaram à escalação das ārvores.

No solo PVE, os clones G-0269 e G-0245 mostram os maiores valores para a atividade da fosfatase ácida, apresentando o melhor colocado (G-0269) superioridade de $72,44 \%$ e $69,98 \%$ daqueles clones com menor atividade enzimática, respectivamente G-0250 e G-0258. Os clones G-0251 e G-0261, ter ceiro e quarto colocados, mostram valores acima de 1,5 umol pnitrofenol.g.matēria fresca-1. min $^{-1}$, e podem ser esquematicamente classificados como clones de maior atividade da fosfatase ācida; juntamente com o G-0269 e G-0245.

o clone de maior atividade da fosfatase ácida no ensaio sob $A Q$, isto é, G-0250, foi o segundo melhor tratamento para as caracteristicas de crescimento em altura e concentração de fósforo nas folhas, enquanto o G-0258, foi o pior tratamento para a atividade da fosfatase ācida e concentração de fósforo nas folhas e sētimo tratamento para crescimento em altura. Para o solo AQ, a classificação dos clones de maior 
atividade enzimática, mostra algumas semelhanças com aquela no PVE, embora com alteração nas posições, que inclue o G0245, G-0269 e G-0251, entretanto, o melhor colocado para esse parâmetro na $A Q$, isto é, O G-0250, foi o pior tratamento no PVE.

O teste de Tukey para comparação de médias de clones não revelóu diferenças significativas ao nível de $5 \%$, embora, na anālise de variāncia o valor de F tenha sido signi ficativo para o ensaio sob PVE.

\subsubsection{Relação da atividade da fosfatase ācida com altura e P nas plantas}

A relação entre atividade da fosfatase ácida com o crescimento em altura e concentração de fósforo nas folhas foi estudada atravēs do"coeficiente de correlação de Spearman". Os valores de $r_{s}$ para atividade da fosfatase ācida e altura foram $-0,52$ e 0,00 , resoectivamente, para PVE e AQ. Observa-se uma tendēncia de correlação inversa entre atividade da enzima e altura das plantas no ensaio sobre PVE, embora o valor não tenha sido significativo pelo teste $t$ ( $t=$ $-1,75)$.

Para atividade da fosfatase ācida e concentração de fósforo nas folhas; os valores de $r_{s}$ foram 0,26 e 0,24, respectivamente, para PVE e AQ. Embora também não tenha sido detectado correlação entre estas características através do tes- 
te $t$, existe uma tendência semelhante para os dois locais, mostrando que plantas com maior concentração de fósforo nas folhas, apresentam maior atividade da fosfatase ácida.

\subsection{Interação gen̄̄tipo-solo}

\subsubsection{Anālises das variâncias conjuntas}

Os resultados das anālises de variāncias (ANO-

VAS) conjuntas para locais, para as caracteristicas de altura, diāmetro, volume sōlido com casca, porcentagem de sobrevivēnCia, concentrações de N, P, Ca, Mg, S, B, Cu, Fe, Mn e Zn, e atividade da fosfatase ācida, nas duas idades avaliadas, são apresentadas nas Tabelas 13 e 14.

Os resultados das anālises de variāncias conjun tas para locais apresentaram valores sempre significativos para todas as caracteristicas e idades, exceto para concentrações de $S$ e Cu e atividade da fosfatase ácida.

As variações genéticas entre clones, para 10cais em conjunto, foram significativas para todas as características silviculturais e para algumas características nutricionais na idade de 12 meses; isto é, concentrações de P, $\mathrm{K}, \mathrm{Ca}, \mathrm{Mg}, \mathrm{B}, \mathrm{Fe}$ e $\mathrm{Mn}$, sendo que a concentração de $\mathrm{K}$ também foi significativa aos 56-57 meses de idade. Para as características silviculturais não houve tendēncia de aumentar ou 
Tabela 13. Resultados da anālise de variāncia conjunta para 15 variāveis, em clones de $E$. grandis nos dois 10 cais (solos), aos 12 e 18 meses de idade, respectivamente, para caracteristicas nutricionais e silviculturais.

Variāveis

Mēdias

F $\quad F$

$F$

CV

gerais

clones

locais Clones XLocais

$\%$

\begin{tabular}{|c|c|c|c|c|c|}
\hline Altura (m) & 8,19 & $6,95 * *$ & $53,98 * *$ & 0,60 & 6,64 \\
\hline $\operatorname{DAP}(\mathrm{cm})$ & 6,78 & $11,51 * *$ & $251,17 * *$ & 1,98 & 5,37 \\
\hline $\operatorname{VSLCCHA}\left(\mathrm{m}^{3} / \mathrm{ha}\right)$ & 15,47 & $14,72^{* *}$ & $187,22 * *$ & 1,50 & 13,27 \\
\hline Sobr. $(\%)$ & 91,67 & $2,40 *$ & $10,12 * *$ & $2,51 *$ & 1,42 \\
\hline$N(\%)$ & 2,25 & 2,12 & $70,82 * *$ & 2,15 & 6,12 \\
\hline$P(\%)$ & 0,11 & $3,92 * *$ & $98,87 * *$ & $2,94 *$ & 10,56 \\
\hline$K(\%)$ & 0,98 & $3,86 * *$ & $4,80 *$ & $3,17 *$ & 8,62 \\
\hline $\mathrm{Ca}(\%)$ & 0,43 & $5,05 * \star$ & $148,22 * \star$ & 2,14 & 12,97 \\
\hline $\operatorname{Mg}(\%)$ & 0,23 & $8,11 * *$ & $128,48 * \star$ & 2,23 & 11,32 \\
\hline $\mathrm{S}(\%)$ & 0,10 & 0,83 & 2,54 & $2,42 *$ & 14,72 \\
\hline$B(p p m)$ & $33,9 \cdot 6$ & $4,53 * *$ & $8,87 \star \star$ & 0,77 & 16,56 \\
\hline $\mathrm{Cu}(\mathrm{ppm})$ & 5,15 & 1,16 & 1,25 & 1,48 & 27,65 \\
\hline $\mathrm{Fe}(\mathrm{ppm})$ & 129,63 & $4,92 * *$ & $15,02 * *$ & 1,08 & 15,52 \\
\hline $\operatorname{Mn}(\mathrm{ppm})$ & 375,63 & $5,03 * *$ & $34,15 * *$ & 2,14 & 9,85 \\
\hline $\mathrm{Zn}(\mathrm{ppm})$ & 13,75 & 1,65 & $41,55 * *$ & 1,71 & 16,94 \\
\hline
\end{tabular}

(\%) Transformado em $\log (x+1)$

* Significativo a $5 \%$ pelo teste $\mathrm{F}$ ** Significativo a $1 \%$ pelo teste $F$ 
Tabela 14. Resultados da anālise de variância conjunta para 16 variāveis, em clones de $E$. grandis nos dois 10 cais (solos), aos 54 e 56-57 meses de idade, respectivamente, para caracteristicas silviculturais e nutricionais.

Variāveis

Médias.

F $\quad F$

$\mathrm{F}$

CV

gerais clones Locais Clones $\times$ Locais \%

\begin{tabular}{|c|c|c|c|c|c|}
\hline Altura (m) & 21,01 & $6,14 * *$ & $258,84 * \star$ & 1,88 & 5,47 \\
\hline $\operatorname{DAP}(\mathrm{cm})$ & 15,57 & 3,86 ** & $205,32 * \star$ & 1,75 & 5,50 \\
\hline $\operatorname{VSLCCHA}\left(\mathrm{m}^{3} / \mathrm{ha}\right)$ & $.189,12$ & $14,29 * *$ & $174,33 * *$ & $5,81 * *$ & 13,03 \\
\hline Sobr. $(\%)$ & 87,24 & $2,50 *$ & $5,39 *$ & 2,02 & 2,37 \\
\hline$N \quad(\%)$ & 2,12 & 1,78 & $7,55^{*}$ & 0,82 & 5,30 \\
\hline$P \quad(\%)$ & 0,12 & 1,66 & $7,32 *$ & 1,54 & 13,21 \\
\hline$k \quad(\%)$ & 0,58 & $2,47 *$ & $52,33 * *$ & $2,86 *$ & 11,37 \\
\hline $\mathrm{Ca}(\%)$ & 0,57 & 0,75 & $256,10 * \star$ & $5,80 * *$ & 9,83 \\
\hline $\operatorname{Mg}(\%)$ & 0,27 & 1,15 & $50,13 * *$ & 0,53 & 0,16 \\
\hline S $\quad(\%)$ & 0,11 & 0,60 & 1,43 & 1,02 & 15,24 \\
\hline$B \quad(p p m)$ & 48,19 & 1,02 & $11,29 * *$ & 0,53 & 20,59 \\
\hline $\mathrm{Cu}$ (ppm) & 5,90 & 1,23 & 3,70 & 0,66 & 62,36 \\
\hline $\mathrm{Fe}(\mathrm{pm})$ & 99,81 & 0,81 & $8,33 * *$ & 0,93 & 36,82 \\
\hline$M n(p p m)$ & 591,77 & 1,21 & $48,40 * \star$ & 1,79 & 23,59 \\
\hline $\mathrm{Zn}(\mathrm{ppm})$ & 11,71 & 0,74 & $5,93 *$ & 0,87 & 60,94 \\
\hline PPASE ${ }^{+}$ & 1,44 & 1,43 & 0,69 & 0,86 & 38,96 \\
\hline
\end{tabular}

${ }^{+} \mu \mathrm{mol}$ p-nitrofenol $\cdot \mathrm{g}$ matēria fresca ${ }^{-1} \cdot \min ^{-1}$

(\%) Transformado em $\log (x+i)$

* Significativo a $5 \%$ pelo teste $F$

** Significativo a $1 \%$ pelo teste $F$ 
diminuir com a idade da planta; por outro lado, para as caracteristicas nutricionais houve tendéncia de diminuir as diferenças entre os clones com a idade da planta.

0 efeito de locais foi bastante expressivo para todas as características, con exceção das concentrações de $\mathrm{S}$ e $\mathrm{Cu}$ e atividade da fosfatase ācida. Houve uma tendēncia para uma redução do efeito de locais com o decorrer da idade para sobrevivência, e concentração de N, P e Zn. Uma tendēncia de aumento do efeito de locais com a idade foi verificada para concentração de $P$ nas folhas das plantas. As variações entre crescimento e concentrações de nutrientes dos clones nos dois locais estão associadas à diferenças edáficas, por que não existem diferenças climāticas entre essas localidades que são bastante próximas. Portanto, esses fatos mostram a susceptibilidade do material genético às características e pro priedades do solo.

A interação de clones por locais não foi muito expressiva para a maioria das características silviculturais e nutricionais, sendo significativa aos 12-18 meses de idade pa ra sobrevivēncia e concentrações de $P, K$ e S, e aos 54-57 meses de idade para volume sōlido com casca por hectare e concentrações de $K$ e Ca. Esses resultados revelam que o comportamento dos clones é estável com a variação do local, para as caracteristicas silviculturais, exceção para o crescimento em volume que mostra valor não significativo aos 12 meses, mas valor altamente significativo aos 54 meses. Por outro lado, 
para algumas caracteristicas nutricionais houve diferenças no comportamento dos clones com a variação do local e também mu danças com a idade. Aos 12 meses, atravēs das anāilises das variāncias conjuntas detectam-se valores significativos de $F$ Entre ciones por solo para as concentraçōes de r, : Ej, enquanto aos 56-57 meses de idade os valores são significativos somente para as concentrações de $K$ e Ca. E importanteres saltar que as necessidades nutricionais das plantas mudam com - decorrer da idade, e assim, as concentrações desses nutrien tes variam em função da idade e da disponibilidade desses nutrientes no solo, alēm de outros fatores.

Os coeficientes de variação experimental foram, de certa forma, concordantes com àqueles obtidos com as anālises das variāncias individuais. Uma tendēncia de decrés cimo no valor do coeficiente de variação com a idade foi observada para concentrações de $\mathrm{Ca}$ e $\mathrm{Mg}$, enquanto, para concentrações de $P, K, B, C u, F e, M n$ e $Z n$ houve uma tendēncia de au mentar com o decorrer da idade.

os diferentes comportamentos dos clones entre os locais podem ser interpretados como uma expressão diferencial dos materiais genéticos de local para local, e que pode refletir na interação de clones por locais (VENCOVSKY, 1987), e em função da variação do erro experimental entre locais (Kä GEYAMA, 1980). Alēm disso, é importante na interpretação da interação de genótipos por locais considerar as mudanças que podem ocorrer no comportamento dos genótipos com o desenvolvi 
mento do talhão, devido ao fenômeno da competição entre árvores, que gera mudanças na expressão das variâncias genéticas (KAGEYAMA, 1983 ).

\section{4.b.L. "Cosficientes de correlação de Spearman"}

Os resultados obtidos nos ensaios para as caracteristicas silviculturais e nutricionais, aos 12-18 e 5457 meses de idade revelaram, como foi abordado anteriormente, certa semelhança para algumas características. Os "coeficien tes de correlação de Spearman", utilizados para a quantificação da associação entre os resultados obtidos, são apresentados nas Tabelas 15 e 16.

A Tabela 15 permite visualizar os "coeficientes de correlação de Spearman" entre as idades de 12-18 e 54-57 meses, obtidos ao nível de mēdias de clones. As correlações estabelecidas revelaram valores significativos pelo teste $t$ para crescimento em altura e sobrevivéncia no ensaio sob PVE, enquanto no ensaio sob $A Q$, além dessas caracteristicas, houve significância dos valores para diāmetro e concentração de M.g nas folhas das plantas.

As caracteristicas nutricionais estudadas não apresentaram os mesmos padrões de uniformidade entre os dois locais, enquanto nas características silviculturais houve uma tendēncia para associações mostrada pela altura e sobrevivēncia, e de certa forma pelo volume, mas o diāmetro revelou ten dências muito distintas entre os solos. 
Tabela 15. "Coeficiente de Correlação de Spearman" para as características das plantas, ao nível de médias de clones, nos dois locais de experimentação - Solo Podzólico Vermelho-Escuro e Solo Areia Quartzosa.

\section{Corre lação $\left(r_{S}\right)$}

Caracteristicas

$$
12-18 \text { meses } \quad 54-57 \text { meses }
$$

A 1 tura

$0,905 * *$

0,143

DAP

$0,833 * *$

0,119

Sobr.

0,119

0,071

VSLLCHA

0,738 * *

0,548

N

$-0,143$

0,310

$\mathrm{P}$

0,048

$-0,095$

0,310

0,262

$\mathrm{Ca}$

0,548

$-0,619$ *

$\mathrm{Mg}$

0,476

0,667 *

$S$

$-0,500$

0,143

$0,738 *$ *

0,119

$\mathrm{Cu}$

$-0,071$

0,214

$\mathrm{Fe}$

0,214

0,262

$\mathrm{Mn}$

0,548

0,286

$\mathrm{Zn}$

$-0,191$

$-0,500$

PPase

* Significativo a $5 \%$ pelo teste t.

** Significativo a $1 \%$ pelo teste $t$. 
Tabela 16. "Coeficiente de correlação de Spearman" para as características das plantas, ao nível de clones, aos 12-18 meses e 54-57 meses de idade.

Características

\section{Correlação $\left(r_{S}\right)$}

$$
\mathrm{PVE}^{1} \quad \mathrm{AQ}^{1}
$$

\begin{tabular}{lcc} 
Altura & $0,738 * *$ & $0,714 *$ \\
DAP & $-0,024$ & $0,762 * *$ \\
Sobr. & 0,452 & 0,548 \\
VSLCCHA & $0,619 *$ & $0,619 *$ \\
$\mathrm{~N}$ & 0,310 & 0,119 \\
$\mathrm{P}$ & $-0,476$ & 0,095 \\
$\mathrm{~K}$ & 0,238 & $-0,333$ \\
$\mathrm{Ca}$ & 0,024 & 0,191 \\
$\mathrm{Mg}$ & 0,095 & $-0,619 *$ \\
$\mathrm{~S}$ & $-0,500$ & $-0,452$ \\
$\mathrm{~B}$ & 0,310 & 0,200 \\
$\mathrm{Cu}$ & 0,476 & $-0,405$ \\
$\mathrm{Fe}$ & $-0,071$ & 0,190 \\
$\mathrm{Mn}$ & 0,000 & 0,048 \\
$\mathrm{Zn}$ & 0,405 & 0,290 \\
\hline
\end{tabular}

1 PVE: Solo Podzólico Vermelho-Escuro, AQ: Solo Areia Quart zosa.

* Significativo a $5 \%$ pelo teste $t$.

** Significativo a $1 \%$ pelo teste $t$. 
Ds resultados mostram para as caracteristicas nu tricionais entre idades tendēncias muito discrepantes, que mostram valores negativos num solo e positivos para o outro solo. Para a concentração de Mg não houve correlação entre idades no solo PVE, jư Ëill, no solo AQ houve correlação negat va significativa.

Embora as correlações para concentração de $S$ não tenham apresentado valores significativos, houve uma tendência de correlação inversa entre as idades, similar para os dois solos.

A Tabela 16 mostra os "coeficientes de correla ção de Spearman" entre solos, para as duas idades. Os resultados mostram que houve maior interação entre os solos aos 12-18 meses, com valores significativos ao nīvel de $1 \%$ pelo teste t, para crescimento em altura, diāmetro e volume, e con centração de B. Com a evolução do ensaio, aos 54-57 meses, hou ve perda. da interação de clones por solo, revelando valores significativos para concentração de Ca e Mg. A correlação ob tida entre solos para concentração de Ca demonstra uma associação inversa aos 57 meses, enquanto aos 12 meses havia uma tendência oposta.

Os resultados obtidos sugerem que vārias alterações ocorrem com a evolução do ensaio, mostrando a necessidade de continuidade desses estudos, para se chegar as conclü sões finais sobre os clones avaliados. Ainda, é importante ressaltar que os resultados obtidos para as características das 
plantas podem não ser aplicāveis para outros clones (CARVALHO, 1985), pois, as matrizes utilizadas foram selecionadas dentro de localidades prōximas aos locais de experimentação. 


\section{CONCLUSÕES}

os resultados obtidos a partir da análise dos dados coletados no teste clonal de Eucalyptus grandis Hill ex Maiden, em dois locais do municipio de Lençōis Paulista - SP, permitem as seguintes conclusões:

a) Com o avanço da idade do experimento houve uma tendēncia à redução dos teores de matéria orgānica nos dois solos, embora, aos 54 meses os valores aindas sejam considerados médios. No ensaio sob Areia Quartzosa (AQ) os niveis de fertilidade e acidez se mantiveram, enquanto no ensaio sob Podzólico Vermelho-Escuro (PVE) houve decréscimo do valor de $\mathrm{pH}$, de $\mathrm{K}^{ \pm}, \mathrm{Mg}^{++}$e $\mathrm{Ca}^{++}$, sendo a redução de $\mathrm{K}^{+}$e $\mathrm{Mg}^{++}$ de $50 \%$, e de $\mathrm{Ca}^{++}$de $82,5 \%$. Aos 54 meses, os valores das bases trocáveis foram considerados baixos nos dois solos, embora estes ainda sejam superiores no PVE, com exceção do $\mathrm{K}^{+}$que mostrou valores equivalentes nos dois solos.

b) Variações genēticas foram detectadas entre clones, aos 18 e 54 meses de idade, para altura, DAP, volume 
e sobrevivência das plantas no ensaio sob PVE, enquanto no en saio sob AQ foram detectadas aos 18 meses para DAP e volume, e aos 54 meses para altura e volume.

c) Variações genēticas foram dotectadas entre clones, aos 12 meses de idade, para as concentrações de $P, K$, $\mathrm{Mg}, \mathrm{B}, \mathrm{Fe}$ e $\mathrm{Zn}$ no ensaio sob $A Q$, enquanto no ensaio sob PVE houve variações para as concentrações de Ca, Mg e Mn. Aos 5657 meses após a instalação do experimento, variações genēticas foram detectadas para as concentrações de K, Ca e Mn no ensaio sob $A Q$, enquanto ño ensaio sob PVE houve apenas variação entre clones para a concentração de $\mathrm{Ca}$.

d) As variações genéticas entre clones para as caracteristicas silviculturais foram mais marcantes no PVE, e para as concentrações de nutrientes as variações entre clones foram mais significativas na $A Q$ e na idade mais precoce.

e) Houve uma tendēncia de aumento dos valores das concentrações de $\mathrm{K}, \mathrm{Ca}, \mathrm{Mg}$ e $\mathrm{Mn}$ com o avanço da idade, e para as concentrações de $P$ e Fe houve uma tendēncia à redução com a idade. Para as concentrações de $N$ e $S$ houve uma tendência à manutenção dos mesmos valores entre as idades estuda das.

f) As relações entre nutrientes $N / P, N / K, N / S$, $\mathrm{P} / \mathrm{K}$ e Ca/Mg revelaram valores muito diferentes daqueles cons $\underline{i}$ derados ótimos. Essas evidēncias sobre o estado nutricional 
das plantas sugerem possiveis alterações metabōlicas, principalmente ao nível de sintese de proteinas e até problemas de lignificação da madeira na idade adulta.

g) Variacão genética entre clones foi detertada para atividade da fosfatase àcida em folhas no ensaio sob PVE, porēm, não houve variação significativa no ensaio sob $A Q$.

h) A interação de clones por locais foi significativa para sobrevivência das plantas e para concentrações de $P, K$ e $S$ aos 12-18 meses de idade, e para volume e concentrações de $\mathrm{K}$ e Mg aos 54-57 meses de idade, refletindo-se em comportamentos relativos diferentes nos ambientes, e assim, perda da eficiēncia de utilização destes pela seleção marginal de clones, comparativamente à seleção por locais.

i) A aplicação do "coeficiente de correlação de Spearman" para o estudo de correlações entre solos, ao nīvel de médias de clones, mostrou a existēncia de correlações positivas e altamente significativas para altura, DAP, volume e concentração de B, aos 12-18 meses de idade. Também na ida de de 12-18 meses observou-se uma tendência à correlação significativa com valores positivos para concentrações de $\mathrm{Ca}$ e Mn, e valor negativo para concentração de S. Aos 54-57 meses, o estudo de correlações entre solos revelou a existência de correlações significativas com valor negativo para concen- 
tração de Ca e valor positivo para a concentração de $\mathrm{Mg}$. Na idade mais avançada foi observado uma tendēncia à correlação significativa positiva para volume e negativa para concentra ção de Zn.

j) 0 estudo de correlações entre idades, ao $n \underline{i}$ vel de média de clones, atravēs do "coeficiente de correlação de Spearman", revelou a existēncia de correlações positivas pa ra altura e sobrevivência nos dois locais experimentais, e para DAP no ensaio sob AQ. Correlação negativa significati va para concentração de $M g$ foi mostrada no ensaio sob $A Q$.

1) 0 estudo de correlações entre atividade da fosfatase ácida e concentração de $P$, ao nível de médias de clones, atravēs do "coeficiente de correlação de Spearman", re velou valores de correlação não significativos para os dois locais. Para o estudo de correlação entre atividade da fosfá tase ácida e altura das plantas, ao nível de média de clones, foi revelado uma tendēncia à correlação negativa significativa no ensaio sob PVE. A falta de correlação entre a atividade da fosfatase ácida e a concentração de $P$ nesse experimen to revela a necessidade de estudos para verificar o papel da fosfatase ācida no metabolismo do fósforo, e as possibilidades da utilização desse parāmetro bioquímico na seleção de genōtipos mais eficientes em fósforo, sob condições de baixa disponibilidade desse nutriente. 


\section{LITERATURA CITADA}

AdAMOLI, J.; MACEDO, J.; AZEVEdo, L.G. de \& MAdeira netTo,J. Caracterização da região dos Cerrados. In: GOEDERT,W.J. Solos dos Cerrados: tecnologias e estratégias de manejo. São Paulo, Nobel; Brasilia, EMBRAPA, cap. 2, 1986 . p.33-. 74 .

ARMSON, K.A. Soil and plant techniques as diagnostic criteriafor evaluating fertilizer needs and treatment response In: Forest fertilization symposium, Proc., USDA For. Serv. NE-3, 1973. p.155-166.

BARRETT-LENNARD, E.G. \& GREENWAy, H. Partial separation and characterization of soluble phosphatases from leaves of wheat grown under phosphorus deficiency and water deficit. Journal of Experimental Botany, 33: 694-704, 1982.

BARRETT-LENNARD, E.G.; ROBSON, A.D. \& GREENWAY, H. Effect of phosphorus deficiency and water deficit on phosphatase activities from wheat leaves. Journal of Experimental Botany, 33: 682-693, 1982.

BARROS, N.F. de. Contribuição ao relacionamento de caracterís ticas pedológicas e topogrāficas com altura de Eucalyptus alba na região de Santa Bärbara. Viçosa, 1974. 89p. (Mestrado - Universidade Federal de Viçosa). 
BARROS, N.F. de. A interação genōtipo-solo em espēcies florestais. Seminārio sobre Interação do Genōtipo com o clima e solo. Piracicaba, IPEF/ESALQ, 1986. p.11-13.

'BATAGLIA, O.C.; FURLANI, A.M.C.; TEIXEIRA, J.P.F.; FURLANI, P. R. \& Gríló, j.R. Métusuj de Anālise Química de Plantus. Boletim Técnico nọ 78, IAC, Campinas, 1983. 48p.

- BAKER, J.E. \& TAKEO, T. Acid phosphatase in plant tissues. I. Changes in activity and multiple forms in tea leaves and tomato fruit during maturation and senescence. Plant \& Ce11 Physiology, 14: 459-471, 1973.

BAULE, H. \& FRICKER, C. The fertilizer treatment of forest trees. Munchen, BLV, 1970. 259p.

BELLOTE, A.F.J. Concentração, acumulação e exportação de nu彑 trientes pelo Eucalyptus grandis (Hill ex Maiden) em função da idade. Piracicaba, 1979. 128p. (Mestrado-Escola Superior de Agricultura "Luiz de Queiroz"/ISPP).

BERTOLOTI, G. Comportamento de clones de Eucalyptus grandis W. Hill Ex Maiden em solo podzólico vermelho escuro e areia quartzosa em Lençōis Paulista-SP. Piracicaba, 1986. 80p. (Mestrado - Escola Superior de Agricultura "Luiz de Queiroz"/USP).

BERTONI, J. \& LOMBARDI NETO, J. Conservação do solo. Piracicaba, Livroceres, 1985. p.30-63.

BESSEY, O.A.; LOWRY, O.H. \& BROCK, M.J. A method for the rapid determination of alkaline phosphatase with five cubic millimeters of serum. Journal of Biological Chemistry, 164: 321-329, 1946 . 
- BESFORD, R.T. A phosphatase as a potencial indicator of the phosphorus of the glasshouse cucumber (Cucumis sativus). Journal of Science and Food Agriculture, 29: 87-91, 1978.

BESFORD, R.T. Quantitative aspects of leaf acid phosphatase activity and the phospiicrus status of ioiiato plants. Annual of Botany, 44: 153-161, 1979.

BESFORD, R.T. A rapid tissue test for diagnosing phosphorus deficiency in the tomato plants. Annual of Botany, 45: $225-227,1980$.

\& BIELESKI, R.L. Phosphate pools, phosphate transport, and phosphate availability. Annual Review of Plant. Physiology, 24: 225-252, 1973.

BOWEN, G.D. Tree roots and the use of soil nutrients. In: BOWEN, G.D. \& NAMBIAR, E.K.S. Nutrition of plantation. forests. London, Academic Press, 1984. cap. 6, p.147-179.

BRADY, N.C. Natureza e propriedades dos solos. 6a ed. Rio de Janeiro, Freitas Bastos, 1983. $665 p$.

BRASIL. Serviço Nacional de Pesquisas Agronōmicas. Comissão de Solos - Levantamento de Reconhecimento dos Solos do Es tado de São Paulo. Rio de Janeiro, Min. da Agricultura, 1960. 634p. (Bo1. 12).

CARVALHO, P.L.P.T. de. Interação genótipo $x$ ambiente em clo nes de Eucalyptus grandis Hill. ex Maiden. Viçosa, 1989. $74 p$. (Mestrado - Universidade Federal de Viçosa).

CATANI, R.A. \& JACINTHO, A.0. Anālise química para avaliar a fertilidade do solo. Boletim Técnico Científico no 37 , ESALQ, Piracicaba, 1974. (mimeografado). 
$\therefore$ DIXON, M. \& WEBB, E.C. Enzymes. 2.ed. New York, Academic Press, 1964. $950 \mathrm{p}$.

DRACUP, M.N.H.; BARRETT-LENNARD, E.G.; GREENWAY, H. \& ROBSON, A.D. Effect of phosphorus deficiency on phosphatase act ivity of ce?l walls from roots of subtanyiredi . cicure. Journal of Experimental Botany, 35: 466-480, 1984.

DRIESSCHE, R. van den. Prediction of mineral status of trees by foliar analysis. The Botanical Review, 40: $347-394$, 1974 .

EPSTEIN, E. Nutrição mineral das plantas: princípios e pers pectivas. Trad. e notas: E. Malavolta, Rio de Janeiro, LTC; São Paulo, EDUSP, 1975. 399p.

FASSBENDER, H.W. Química de suelos, con ēnfasis en suelos de America Latina. San José, IICA, 1982. $398 p$.

FERREIRA, F. de A. da S. A interação nitrato, fosfato e sulfato na absorção de fosfato e de sulfato no crescimento de eucalipto e no seu metabolismo de nitrato e sulfato. Viçosa, 1986. 95p. (Mestrado - Universidade Federal de $V i c ̧ o s a)$.

FORREST, W.G. \& OVINGTON, J.D. Variation in dry weight and mineral nutrient content of Pinus radiata progeny. Silvae. Genetica, 20: 174-179, 1971.

FOTH, H.D. Fundamentals of Soil Science. 7ạ ed. New York, John Willey \& Sons, 1984. p.21-62.

FURTINI NETO, A.E. Efeito do enxofre no crescimento e assimilação de nitrogēnio por diferentes espēcies de eucalipto. Lavras, 1988. 95p. (Mestrado - Escola Superior de Agricultura de Lavras). 
GOEDERT, W.J. Solos dos cerrados: tecnologias e estratégias de manejo. São Paulo, Nobel; Brasilia, EMBRAPA, 1986. $422 p$.

GOLFARI, L. Zoning for reflorestation in Brazil and trials with troiriu: Eucaxuptis is d pines in Central region. Ba. 10 Horizonte, IBDF, 1978 (Relatōrio Técnico nọ 12).

GONÇALVES, J.C. Comportamento do Eucalyptis grandis Hill ex Maiden em dois solos de baixa fertilidade, em Angatuba-SP. Piracicaba, 1987. 71p. (Mestrado - Escola Superior de Agricultura "Luiz de Queiroz"/USP).

HAAG, H.P.; SARRUGE, J.R.; OLIVEIRA, G.D. de; POGgIANI, F. \& FERREIRA, C.A. Anālise foliar em cinco espēcies de Eucaluptus. IPEF, 13: 99-115, 1976.

"HAN, S.W. \& ROSSI, A. Acid phosphatase (E.C. 3.1.3.2.) synthesis by phosphorus regulatory mutants strains of Neurospona crassa. Brazilian Journal of Medicine and Biology Research, 22: 423-431, 1989 .

HARIDASAN, M. Acumulation of nutrients by eucalyptus seedlings from acidic and calcareous soils of the cerrado re gion of Central Brazil. Plant and Soil, 86: 35-45, 1985.

HASEGAWA, Y.; LYNN, K.R. \& BROCKBANK, J. Isolation and partial characterization of cytoplasmic and wall-bound acid phosphatase from wheat roots. Canadian Journal of Botany, 54: $1163-1169,1976$.

- HEVITT, E.J. \& TATHAM, P. Interaction of mineral deficiency and nitrogen source on acid phosphatase activity in leaf extracts. Journal of Experimental Botany, 11: $367-375$, 1960 . 
HUMPHREYS, F.R.; TURNER, J. \& WATT, A.J. Annual foliar nutrient level variation in pinus radiata over a nine year period. In: Australian Forest Nutrition Conf., Canberra, 1971 . p.258-270.

KAGEYAMA, P.Y. Variação geñ̈tica erilie y"usedērcịas de Pinus oocarpa Schiede na região de Agudos-SP. Piracicaba, 1977. 80p. (Mestrado - Escola Superior de Agricultura "Luiz de Queiroz"/USP).

KAGEYAMA, P.Y. Variação genētica em progēnies de uma popu1 ação de Eucalyptus grandis (Hii1) Maiden. Piracicaba, 1980 . 125p. (Doutorado - Escola Superior de Agricultura "Luiz de Queiroz"/USP).

KAGEYAMA, P.Y. Seleção precoce a diferentes idades em progēnies de Eucalyptus grandis (Hi11) Maiden. Piracicaba, 1983. 147p. (Livre-Docēncia-Escola Superior de Agricul tura "Luiz de Queiroz"/USP).

KAMPRATH, E.J. Exchangeable aluminium as a criterion for liming mineral soils. Soil Science of Society of America. proceedings, 34: 252-254, 1970.

KAUL, O.N.; SRIVASTAVA, P.B.L. \& TANDON, V.N. Nutrition stu dies on Eucalyptus. III. Diagnosis of mineral deficiencies in Eucalyptus grandis seedlings. Indian Forester, 94: $831-834,1968$.

KHANNA, P.H. \& ULRICH, B. SOil characteristics influencing nutrient supply in forest soils. In: BOWEN, G.D. \& NAMBIAR, E.K.S. Nutrition of plantation forests. London, Academic Press, 1984. cap. 4, p.79-117. 
KIEHL, E.J. Manual de Edafologia. Relações Solo-Planta. Pi racicaba, Ceres, 1979. p.230-245.

LAMB, D. Variations in the foliar concentrations of macro and micro elements in a fast growing tropical eucalypt. piant aris soii, 45: 477-492, 1976.

LAMB, D. Relationships between growth and foliar nutrient concentrations in Eucalyptus deglupta. Plant and Soil, 47: 495-508, 1977.

LAMBERT, M.J. \& TURNER, J. Interpretation of nutrient concentration in Pinus radiata foliage at Belanglo state for est. Plant and Soil, 108: 237-244, 1988.

LAVENDER, D.P. Foliar analys is and how it is used. A review. Corvallis, Oregon, School of Forestry, Oregon State University, 1970. 8p. (Research Note 52).

LEAF, A.L. Plant analysis as an aid in fertilizing forests. In: Soil Testing and Plant Analysis. 2.ed. Madison, Soil Sci. Soc. Amer. Inc., 1972. p.427-454.

LEAL, P.G.L. Produção de biomassa e distribuição de nutrien tes em Eucalyptus grandis influenciadas pela aplicação de fosfato natural em solos de cerrado. Viçosa, 1988. 44p. (Mestrado - Universidade Federal de Viçosa).

LEE, R.B. \& RATCLIFFE, R.G. Phosphorus nutrition and the intracellular distribution of inorganic phosphate in pea root tips: a quantitative study using 31P-NMR. Journal. of Experimental Botany, 34: 1222-1244, 1983.

LEPSCH, I.F. Influēncia do cultivo de Eucalyptus e Pinus nas propriedades químicas de solos sob cerrado. Revista Brasileira de Ciência do Solo, 4: 103-107, 1980. 
LOPES, A.S. \& COX, F.R. A survey of the fertility status of surface soils under "Cerrado" vegatation in Brazil. Soil. Science of Society of America Journal, 41: 742-747, 1977.

LOPES, A.S. Solos sob "Cerrado". Caracteristicas, propriedade e minicio. Za ed. Fi.acicaba, POTAFOS, 1984.162p.

MAC LEAN, K.S. \& ROBERTSON, R.G. Variation in the major element content of red spruce foliage with season, crown position, tree and tissue age. Communications in soil Science and Plant Analysis, 12: 13-49, $1981 \mathrm{a}$.

MAC LEAN, K.S. \& ROBERTSON, R.G. Trace element levels in red spruce and the effect of age, crown and seasonal chan ges. Communications in Soil Science and Plant Analysis, 12: $483-493,1981 b$.

MALAVOLTA, E.; HAAG, H.P.; MELLO, F.A.F. de \& BRASIL SOBRINHO, M.0.C. Nutrição mineral e adubação de plantas cul-. tivadas. São Paulo, Pioneira, 1974. 752p.

MALAVOLTA, E. \& KLIEMANN, H.J. Desordens nutricionais no. cerrado. Piracicaba, POFATOS, 1985. 136p.

MALAVOLTA, E. \& MALAVOLTA, M.L. Diagnose foliar - principios e aplicações. In: BULL, L.T. \& ROSOLEM, C.A. Interpretação de análise química de solo e planta para fins de. adubação. Botucatu, FEPAF, 1989. p.227-308.

McCOLL, J.G. Soil-plant relationships in a Eucalyptus forest on the south coast of New South Wales. Ecology, 50:354360,1969 .

- MCLACHLAN, K.D. Comparative phosphorus responses in plants to a range of available phosphorus situations. Australian Journal of Agriculture Research, 27: 323-341, 1976. 
MCLACHLAN, K.D. Acid phosphatase activity of intact roots and phosphorus nutrition in plants. I. Assay conditions and phosphatase activity. Australian Journal of Agriculture Research, 31: 429-440, 1980 .

GuLCHLAN, K.D. Leaf acid phusphatase aetivity and the phosphorus status of field-grown wheat. Australian Journal of Agriculture Research, 33: 453-464, 1982.

MEAD, D.J. Diagnosis of nutrient deficiencies in plantations. In: BOWEN, G.D. \& NAMBIAR, E.K.S. Nutrition of plantation forests. London, Academic Press, 1984. p.259-291.

MELLO,F. de A.F. de; BRASIL SOBRINHO, M. de O.C.; ARZOLLA, S.; SILVEIRA, R.I.; COBRA NETO, A. \& KIEHL, J. de C. Fertilidade do Solo. 3ạ ed., São Paulo, Nobel, 1985. 400 p.

- MENGEL, K. \& KIRKBY, E.A. Principles of Plant Nutrition. 3a ed. Berne, International Potash Institute, 1982. $644 p$.

:NEWMARK, M.Z. \& WENGER, B.S. Preparation and some properties of an acid phosphatase from white lupine seedlings. Archives of Biochemistry and Biophysics, 89: 110-117, 1960.

O'CONNEL, A.M. \& GROVE, T.S. Acid phosphatase activity in karri (Eucalyptus diversicolon F. Muel1.) in relation to soil phosphate and nitrogen supply. Journal of Experi-. mental Botany, 36: 1359-1372, 1985.

PATINO-VALERA, F. Variação genētica em progēnies de Eucaluıptus saligna smith e sua interação com o espaçamento. Piracicaba, 1986. 192p. (Mestrado - Escola Superior de Agricultura "Luiz de Queiroz"/USP). 
PAYN, T.W. \& CLOUGH, M.E. Seasonal variation of foliar nutrient concentrations in Pinus radiata in the Southern Cape. South African of Forestry Journal, 143: 37-41, 1987.

PEREIRA, A.R.; BARROS, N.F. de \& ANDRADE, D.C. Concentração e distribuição de ilutrientes em Eucalyptus grumuis em funçã da idade, cultivado na região do cerrado. XIX Congresso Brasileiro de Ciēncia do Solo, Curitiba, 1983.

PEREIRA, J. \& PERES, J.R.R. Manejo da matéria orgānica. In: GOEDERT, W.J. Solos dos Cerrados: Tecnologias e estraté gias de manejo. São Paulo, Nobel; Brasilia, EMBRAPA, cap. 10, 1986-. p.261-284.

PIMENTEL GOMES, F. Curso de Estatîstica Experimental. 11. ed. Piracicaba, Nobel, 1985. 474p.

PITTA, G.V.E. Correção da acidez do solo utilizando o método de $A 1^{+3}$ trocável e efeitos dela decorrentes em seis uni dades de solos. Piracicaba, 1974. 152p. (Mestrado - Es cola Superior de Agricultura "Luiz de Queiroz"/USP).

PRICE, C.A. Repression of acid phosphatase synthesis in Euglena gracilis. Science, 135: 46, 1962.

QUIJADA, R.M. Genotype-environment interaction. In: FAO. Forest tree improvement. Merida-Venezuela, FAO/DANIDA Jan/Fev. 1980, Rome, FAO, 1985. 190p.

RAIJ, B. van. Avaliação da fertilidade do solo. 2ạ ed. Piracicaba, POTAFOS, $1983.142 p$.

RAIJ, B. Van \& PEECH, M. Electrochemical properties of some oxisols and Afisols of the Tropics. Soil Science of Society of America Proceedings, 36: 587-593, 1972. 
RAIJ, B. van \& QUAGgIO, J.A. Novos métodos de solos do Instituto Agronōmico. Versão Preliminar. Campinas, IAC, 1982. $8 p$.

RAIJ, B. van; QUAGGI0, J.A. \& SILVA, N.M. da. Extraction of phosphorus, pucassium, sa? siuin, and magnesium from soils by an ion-exchange resin procedure. Communications in. Soil Science and Plant Analysis, 17: 547-566, 1986.

ROCHA FILHO, J.V. de C. Interação fósforo, boro, zinco e ca lagem em mudas de Eucalyptus grandis (Hill ex-Maiden) cul tivadas em latossol vermelho escuro de cerrado. Piracica ba, 1979. 105p. (Mestrado - Escola Superior de Agricultü ra "Luiz de Queiroz"/USP).

RODRIGUES, L.C. Relação entre parāmetros silviculturais e concentração de $P, K, C a$ e $M g$ em ārvores de Eucalyptus saligna Smith em Brotas-SP. Piracicaba, 1986. 57p. (Mestrado - Escola Superior de Agricultura "Luiz de Queiroz"/ USP).

SARRUGE, J.R. e HAAG, H.P. Anālise quïmica em plantas. Piracicaba, ESALQ, 1974. 56p.

SANCHEZ, P.A. Suelos del tropico: caracteristicas y manejo. San José, IICA, 1981. $634 p$.

SCHOFIELD, R.K. \& TAYLOR, A.W. The measurement of soil pH. Soil Science of Society of America Proceedings, 19: 164167,1955 .

SCHONAU, A.P.G. Seasonal changes in foliar nutrient content of E. grandis. IUFRO Symposium Brazil, 1980. South African Forestry Journal,. 119: 1-4, 1981. 
SCHONAU, A.P.G. Fertilization in South African Forestry. South. African Forestry Journal, 125: 1-19, 1983.

- SHAYKH, M.M. \& ROBERTS, L.W. A histochemical study of phosphatases in root apical meristems. Annual of Botany, 38: iú-174, 1974.

SHAW, J.G. Acid phosphatase from tobacco leaves. Archives of Biochemistry and Biophysics, 117: 1-9, 1966.

SILVA, H.D. da. Biomassa e aspectos nutricionais de cinco espécies do gēnero Eucalyptus, plantadas em solo de baixa fertilidade. Piracicaba, 1983. 91p. (Mestrado - Escola Superior de Agricultura "Luiz de Queiroz"/USP).

SNEDECOR, G.W. \& COCHRAM, W.G. Statistical Methods. 6? ed. Ames, Iowa St. Univ., 1974. 593p.

SOUZA, E.C.A. de. Micronutrientes do Solo. In: BULL, L.T. \& ROSOLEM, C.A. Interpretação de anālise química de solo e. planta para fins de adubação. Botucatu, FEPAF, 1989.p. $174-205$.

SNOWDON, P. \& WARING, H.D. Between-tree and between-plot variations of nutrient levels in Pinus radiata foliage and their implications for field sampling intensity. Australian Forestry Research, 13: 45-56, 1982.

SNOWDON, P. \& WARING, H.D. Composite samples for foliar analysis. Australian Forestry Research, 14: 235-242, 1984.

TISDALE, S.L.; NELSON, W.L. \& BEATON, J.D. SOil fertility and fertilizers. 4ạ ed. New York, Macmillan Pub., 1985. p. $350-413$. 
- UEKI, K. \& SATO, S. Regulation of phosphatase synthesis orthophosphate in cultured tobacco cells. Plant and Cell Physiology, 18: 1253-1263, 1977.

VAN GOOR, C.P. \& NASCIMENTO, R. Adubação em plantações florestais... Prasil fiorestal, 1: 35-42, 1970.

VENCOVSKY, R. Herança quantitativa. In: PATERNIANI, E. (coord.). Melhoramento e Produção de Milho. I. Piracicaba, Cargi11, 1987. p.137-214.

WHITE, D.P. Variation in the nitrogen, phosphorus, and potas sium of pine needles with season, crown position, and sample treatment. Soil Science of Society of America Proceed ings, 18: 326-330, 1954 . 
113.

A P $\underline{\underline{E}} \underline{N} \underline{D} \underline{I} \underline{\mathrm{C}} \underline{\mathrm{S}}$ 


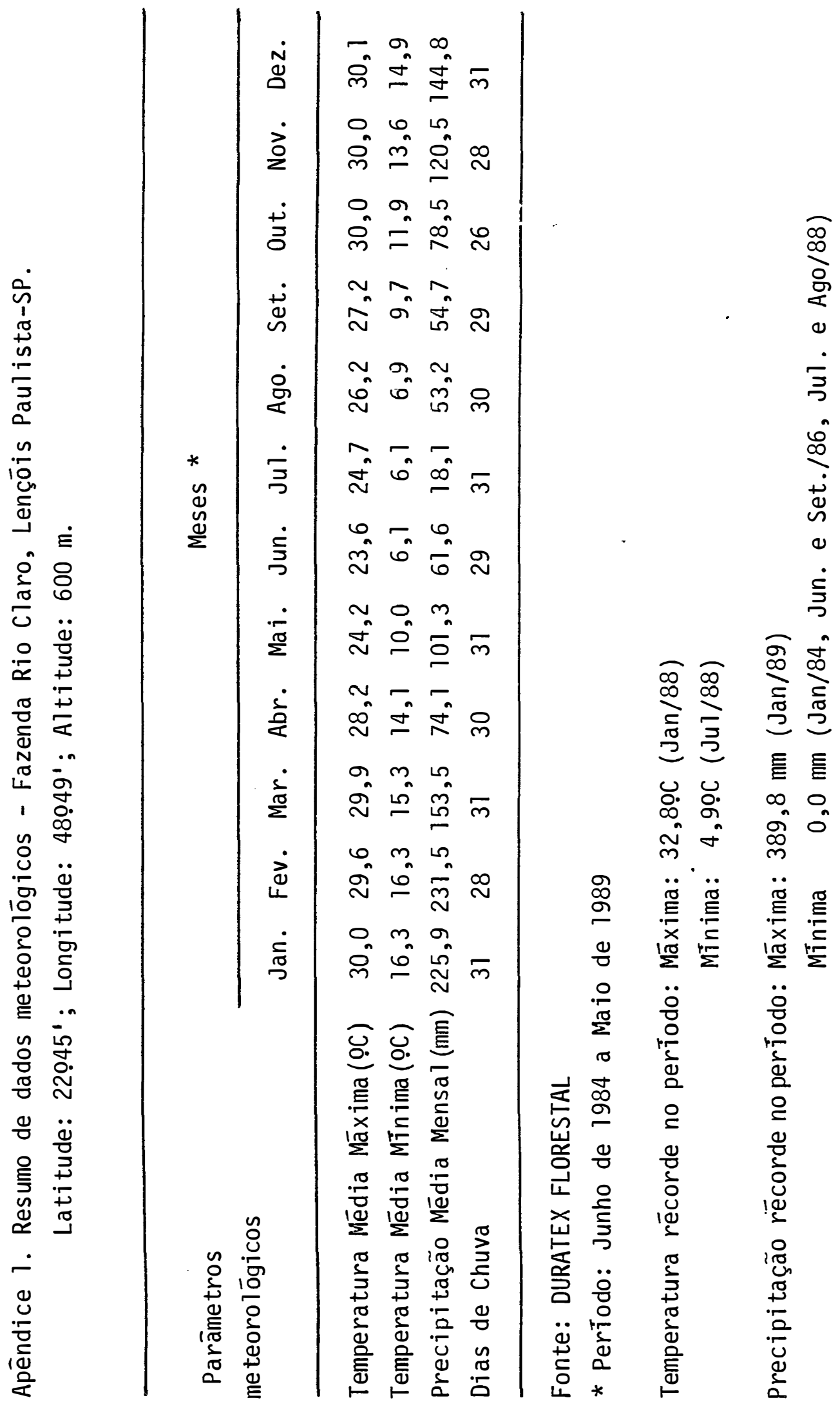




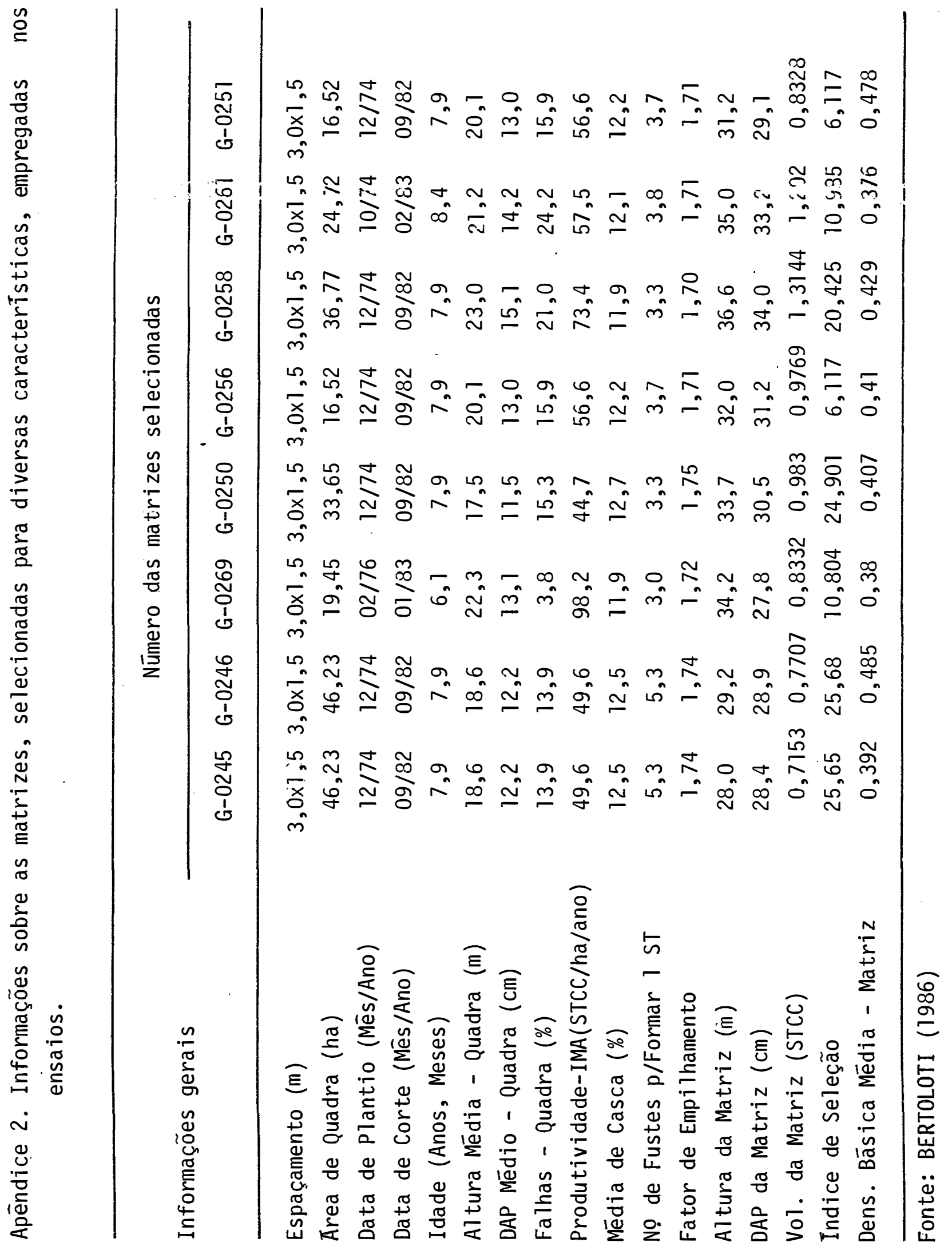

